\title{
ÁRVORES E ARBORIZAÇÃO URBANA NA CIDADE DE PIRACICABA/SP: UM OLHAR SOBRE A QUESTÃO À LUZ DA EDUCAÇÃO AMBIENTAL
}

\author{
ILZA MARIA MONICO
}

Dissertação apresentada à Escola Superior de Agricultura "Luiz de Queiroz", Universidade de São Paulo, para obtenção do título de Mestre em Ciências, Área de Concentração: Ciências Florestais.

P I R A C I C A B A

Estado de São Paulo - Brasil

Novembro - 2001 


\section{ÁRVORES E ARBORIZAÇÃO URBANA NA CIDADE DE PIRACICABA/SP: UM OLHAR SOBRE A QUESTÃO À LUZ DA EDUCAÇÃO AMBIENTAL}

\section{ILZA MARIA MONICO}

Engenheiro Agrônomo

Orientador: Prof. Dr. MARCOS SORRENTINO

Dissertação apresentada à Escola
Superior de Agricultura "Luiz de
Queiroz", Universidade de São Paulo,
para obtenção do título de Mestre em
Ciências, Área de Concentração:
Ciências Florestais.

P I R A C I C A B A

Estado de São Paulo - Brasil

Novembro - 2001 
Dados Internacionais de Catalogação na Publicação (CIP) DIMSÃO DE BIBLIOTECA E DOCUMENTAÇÃO - ESALQ/USP

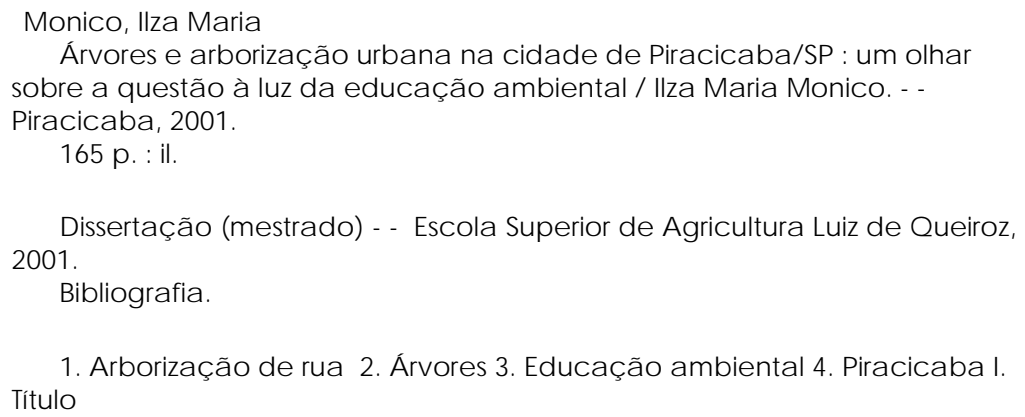

CDD 715.2

\section{"Permitida a cópia total ou parcial deste documento, desde que citada a fonte - $\mathrm{O}$ autor"}




\section{DEDICATÓRIA}

Dedico este trabalho

às árvores da minha infância: às goiabeiras (inclusive as dos vizinhos);

àquele imenso pau-d'alho, sobre cujas raízes quebrávamos macaúbas; ao pomar de laranjeiras e mexeriqueiras, sob o qual brincávamos de casinha; às amoreiras generosas; ao pé-de-cola, cujos frutos colavam nossas pipas (ou papagaios); às santa's-bárbaras que nos emprestavam suas flores e "bolinhas" que enfeitavam nossos bolos de terra; às paineiras, pelos curiosos frutos de algodão; às nespereiras e mangueiras, que ofereciam, além de frutos deliciosos, poltronas confortáveis entre seus galhos, para que passássemos horas à sonhar.

às árvores do meu presente, estas pelas quais eu luto hoje.

às árvores do meu futuro, que eu espero, povoem abundantemente as nossas cidades e o nosso planeta.

\section{Dedico ainda}

Ao Tiago, filho querido, que tem em si um amor imenso pelas árvores; Ao Jean Paul, pelo apoio irrestrito e exemplos constantes de dedicação e nobreza de caráter;

Aos meus pais Otávio e Tereza, pela oportunidade desta existência; Aos meus irmãos Marcos e Silvia, que compartilharam de minha infância com as árvores;

Ao Mestre Sim, cujos ensinamentos e exemplos de virtude têm guiado meu espírito. 


\section{AGRADECIMENTOS}

Ao Marcos pela confiança, compreensão, apoio e orientação; e sobretudo por terme permitido compartilhar de seus ideais de transformação;

Ao Rawson, que acompanhou esta jornada, oferecendo apoio e companheirismo;

Ao Prof. Natal e à Prof ${ }^{\mathrm{a}}$. Silvia Molina, pelas valiosas contribuições no exame de qualificação;

À Cristina (Cri) e à Cristina (Lhama), amizades preciosas que vieram junto com este mestrado, pelas contribuições, incentivos e carinho;

Aos amigos do Laboratório de Educação e Política Ambiental: Ana Paula, Simone, Sandra, Marco (Japi), Isis, Maurício, Marcia, Glaucia, Flavia, Sueli, Mônica, Desirrê e Claudia pelas inúmeras oportunidades de amadurecimento pessoal e profissional compartilhadas, e especialmente ao Vitor, porque além disso, deu uma ajuda fundamental nesta etapa final do trabalho;

Ao profissionais Marcelo Crestana, Juan Sebastianes e João Pauli pelas contribuições valiosas;

Aos profissionais da SEDEMA: Lídia, Tom, Arlete, Gisele, Rogério Vidal, Téia, Maurício e ao Capitão Mendes do Pelotão Ambiental, pela atenção e disposição na prestação das informações e dados utilizados na pesquisa;

Ao Jorge e aos integrantes do grupo de jovens, bem como à Dalva e aos demais integrantes do grupo de terceira idade, pelo empréstimo das fotos e pelo respeito, colaboração e atenção com que encararam este trabalho;

À Analícia, Nelson e Isadora, pela poesia do Brandão, e por terem me apresentado ao Mestre, que sem dúvida, teve grande "participação" neste trabalho.

À Ronaldia, Adriano e Rafael, por terem cuidado do Tiago quando precisei;

À Capes, pela bolsa concedida. 


\section{SUMÁRIO}

Página

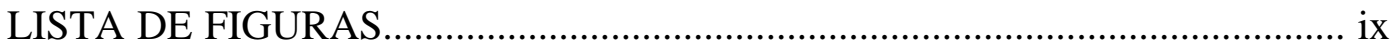

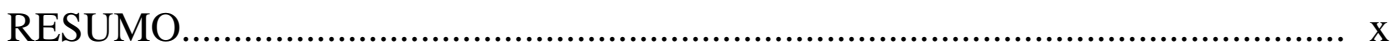

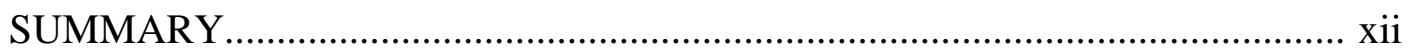

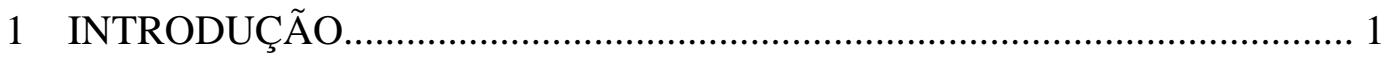

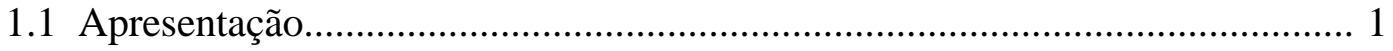

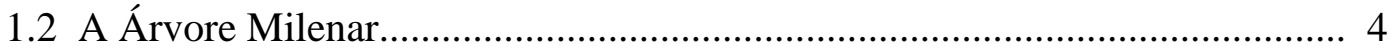

1.3 Piracicaba e sua arborização................................................................ 7

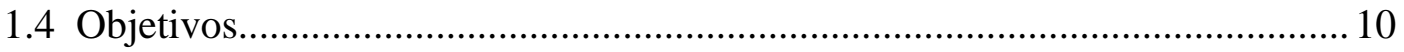

2 REVISÃO DE LITERATURA........................................................ 11

2.1 Dos Bosques Sagrados à Arborização Urbana.............................................. 11

2.1.1 Simbologia e Significados das Árvores na História.................................... 11

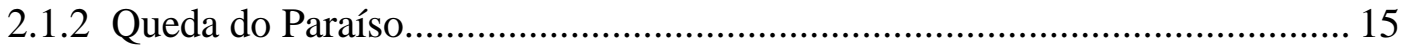

2.1.3 Crise Ambiental e emergência de novos valores....................................... 18

2.1.4 Razão versus Sensibilidade....................................................................20

2.1.5 Percepção da Natureza na Cidade.............................................................22

2.1.6 Participação e cidadania.................................................................. 24

2.1.7 A Presença das Árvores nas Cidades: Origem e Conceito

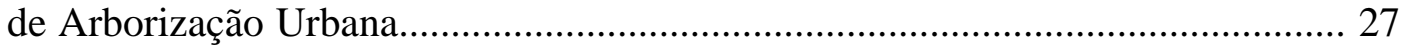

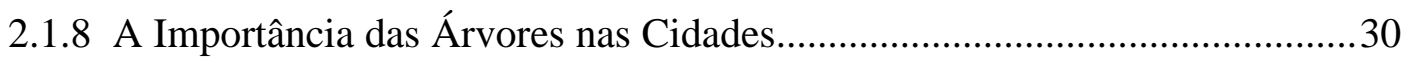

2.1.9 Árvores, ambiente urbano e pessoas: uma convivência delicada...................33

2.1.10 A predominância de espécies exóticas na arborização urbana..................... 37

2.2 O Papel da Educação Ambiental.............................................................. 39 


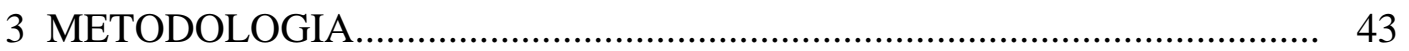

3.1 Referenciais Metodológicos.......................................................................... 44

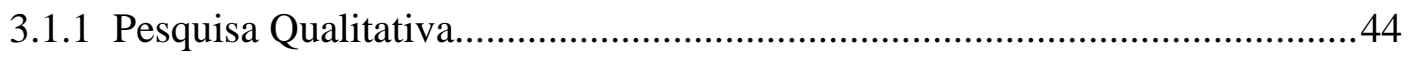

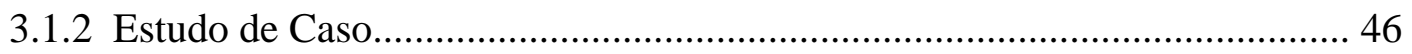

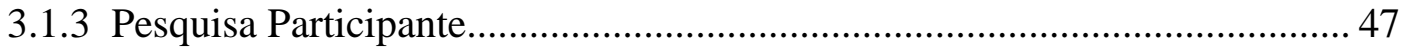

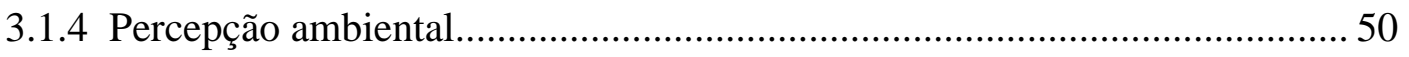

3.2 Técnicas utilizadas na Fase 1........................................................................ 51

3.3 Técnicas Utilizadas na Fase 2 ………………............................................ 53

3.3.1 A escolha dos grupos pesquisados/aproximação/número de

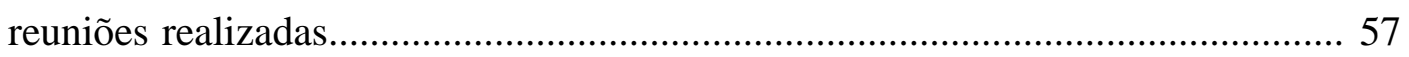

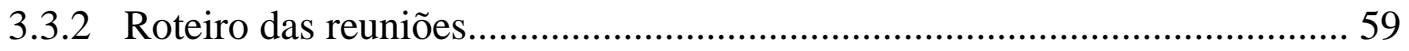

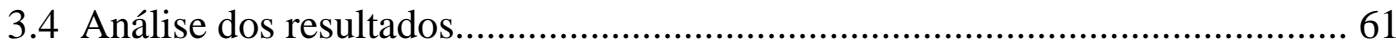

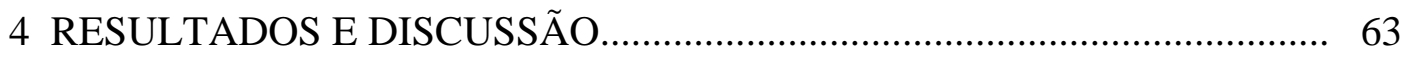

4.1 Resultados e Discussão da Fase 1...........................................................63

4.1.1 Arborização Urbana em Piracicaba: literatura científica e participação da

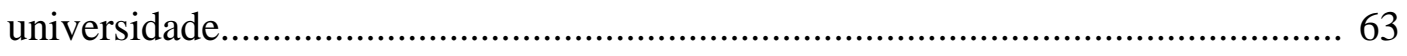

4.1.2 Gerenciamento da arborização viária em Piracicaba..................................... 67

4.1.3 Pressões políticas: cortes de árvores = "Indústria de votos"........................... 75

4.1.4 Critérios Técnicos para Corte de Árvores Viárias...........................................77

4.1.5 Espécies mais afetadas de acordo com os laudos examinados....................... 81

4.1.6 Falhas de manejo comprometem saúde de Sibipirunas e demais

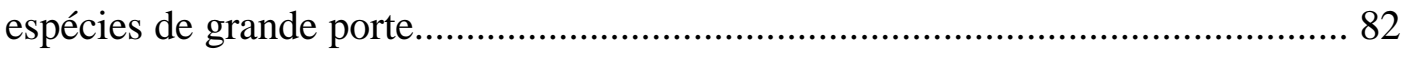

4.1.7 Novos Plantios e Espécies utilizadas: Submissão às regras da CPFL

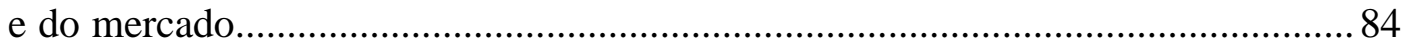

4.1.8 Projetos e campanhas educativas.................................................................. 90

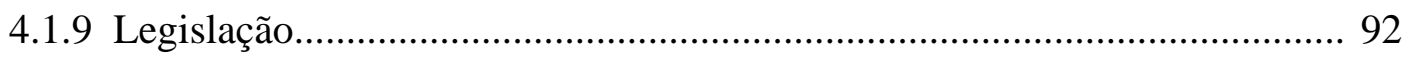

4.1.10 Viveiro Municipal.............................................................................. 95

4.1.11 A Atuação do Pelotão Ambiental................................................................... 97 


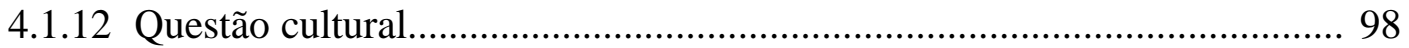

4.1.13 Repercussão nos jornais e pressão popular...…………………………..... 100

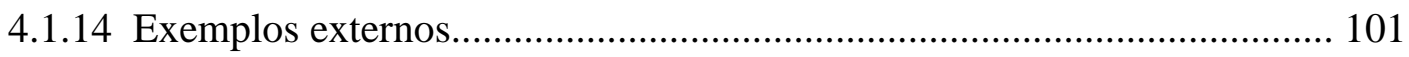

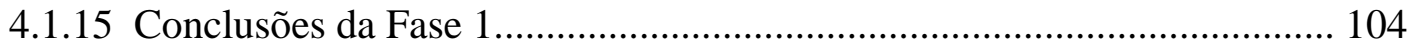

4.2 Resultados e discussão da Fase2 …………………................................. 107

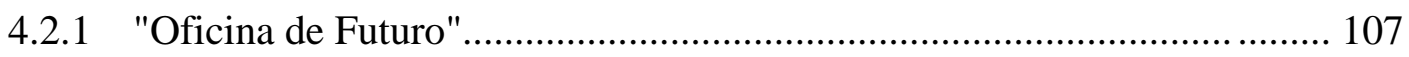

4.2.2 Percepção ambiental/fotografias/expressão artística.................................. 116

4.2.3 Apresentação de material ilustrativo/slides................................................. 123

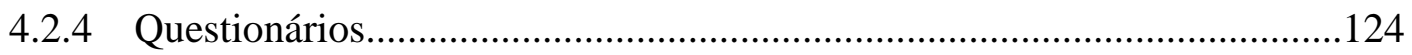

4.2.5 Conclusões sobre os resultados da pesquisa com arborização......................126

4.2.6 Conclusão sobre os efeitos da pesquisa participante nos grupos.................127

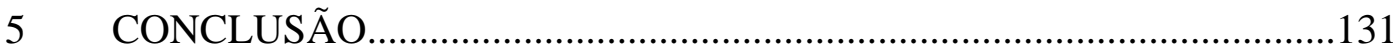

5.1 Considerações finais e sugestões............................................................131

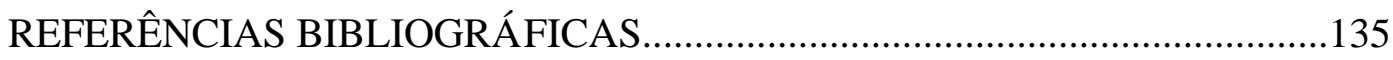

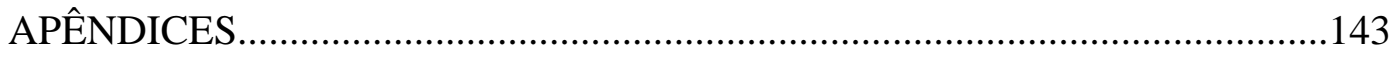




\section{LISTA DE FIGURAS}

Página

1 Jequitibá Rosa de 3.000 anos - Santa Rita do Passa Quatro/SP....................... 6

2 Rua de Piracicaba praticamente desprovida de arborização.............................. 68

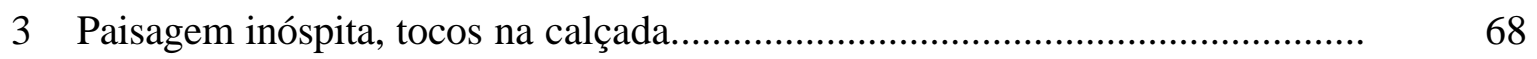

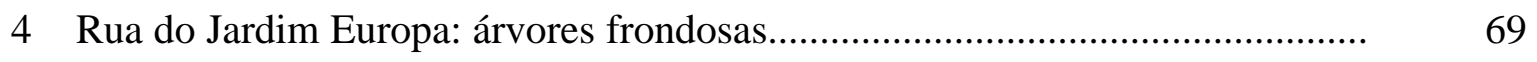

5 Rua do bairro Nova Piracicaba: arborização abundante................................... 69

6 Fluxograma da SEDEMA - Secretaria Municipal de Defesa do Meio Ambiente-Organograma de funcionamento - Ano 1999.................. 70

7 Mapa de Piracicaba, mostrando as divisões administrativas em setores........... $\quad 72$

8 Calçada Verde....................................................................................... 89

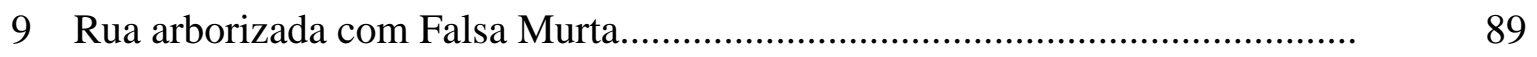

10 Foto antiga trazida por um integrante do grupo de jovens.............................. 112

11 "Subindo em árvores, quando elas existiam". Foto de infância de um integrante do grupo de jovens, hoje com 27 anos................................ 112

12 Filho de uma integrante do grupo de terceira idade brincando num terreno baldio em frente à sua casa..................................................... 115

13 Em meio à frondosas e floridas árvores, o filho com o neto. Os próprios moradores construíram este espaço.

14 Fotografia tirada por integrante do grupo de jovens retratando cenários do seu bairro.................................................................. 116

15 Fotografia tirada por integrante do grupo de jovens retratando cenários do seu bairro.

16 Fotografia tirada por integrante do grupo de terceira idade retratando cenários da cidade.

17 Fotografia tirada por integrante do grupo de terceira idade retratando cenários da cidade.

18 Desenho de quadrinhos feito por integrante do Grupo de Jovens 


\section{ÁRVORES E ARBORIZAÇÃO URBANA NA CIDADE DE PIRACICABA/SP: UM OLHAR SOBRE A QUESTÃO À LUZ DA EDUCAÇÃO AMBIENTAL}

Autora: ILZA MARIA MONICO

Orientador: Prof. Dr. MARCOS SORRENTINO

\section{RESUMO}

Este estudo foi realizado com o objetivo de investigar o estado da arborização viária em Piracicaba/SP, em termos de administração pública e gerenciamento, legislação e ações educativas, procurando conhecer a opinião da equipe técnica envolvida na questão. Paralelamente buscou-se através de pesquisa participante, compreender os anseios e necessidades de um segmento de sua população, os motivos que a levam a enxergar o elemento "árvore" com preconceito ou de maneira negativa, motivando-a a desejar e solicitar os cortes sucessivos atualmente praticados. Procurou-se identificar os fatores que poderiam estimular mudanças de atitude e elementos que possam ser utilizados em campanhas educativas visado o resgate de um relacionamento melhor entre a população e as árvores viárias. A pesquisa conclui que a arborização viária da cidade está comprometida pela inexistência de uma política pública favorável e definida para a questão da arborização urbana na cidade. As mudanças de gestão política têm influenciado negativamente o quadro desta arborização, que não foi implantada de maneira planejada. Por isso, árvores de grande porte estão sendo suprimidas sistematicamente das ruas, sendo substituídas em sua maioria por espécies de pequeno e médio portes, de menor efeito ambiental, quase sempre atendendo à regras estabelecidas 
pela CPFL e aos preconceitos da população. Questiona-se os critérios técnicos adotados pela prefeitura para autorizar os cortes e também a falta de um preparo mais filosófico e educacional entre os profissionais encarregados de seu gerenciamento e administração. Esta formação poderia levá-los a desenvolver em si mesmos um sentimento de maior afetividade e compromisso para com as árvores e a arborização da cidade, o que se constituiria num exemplo para a população. A pesquisa realizada com dois grupos de moradores da cidade aponta que, problemas relacionados com a quebra do calçamento viário provocado pelo crescimento das raízes das árvores, a "sujeira" proveniente da queda de folhas e flores, a interferência na rede elétrica e o entupimento de calhas são os mais percebidos e apontados pelo segmento de população pesquisado. Porém, discussões e reflexões sobre o assunto, realizadas com os grupos, revelaram uma predisposição a buscar-se soluções que não impliquem no sacrifício da arborização. Além disso, os itens "beleza" e "sombra" foram apontados como mais importantes entre os benefícios da arborização urbana. A pesquisa participante, como recurso metodológico utilizado na abordagem do assunto junto aos grupos pesquisados, estimulou o aumento da percepção sobre seu meio ambiente, trazendo à tona um sentimento de apropriação e co-responsabilidade por seus espaços coletivos, e um potencial para pensar e agir sobre sua realidade. Tendo em vista estes resultados, recomenda-se a formulação e implantação, pela administração do município, de uma política pública voltada à incrementar e melhorar a qualidade da arborização urbana na cidade, pautada na evidência de que não existe "árvore ideal" na situação do ambiente urbano, mas que ao invés dessa busca, é preciso, através de projetos educativos abrangentes, estimular o desenvolvimento de valores e sentimentos de maior tolerância, respeito e afeto pelas árvores entre a população. 


\title{
TREES AND ABORIZATION IN PIRACICABA/SP: A VIEW ON THE ISSUE UNDER THE ENVIRONMENTAL EDUCATION
}

\author{
Author: ILZA MARIA MONICO \\ Adviser: Prof. Dr. MARCOS SORRENTINO
}

\section{SUMMARY}

The objective of this study was to investigate the street arborization in Pracicaba city, São Paulo State, taking into account the public management, legislation and educative actions and looking for understanding the technical opinion of professionals involved in this issue. It was also used participatory research to understand the needs of a population segment, and the reasons that this segment sees the element "tree" with preconception or in a negative way, showing desire to request successive trees cut made nowadays. It was also tried to identify factors that could stimulate change in the population mind and could be used in an educative advertising to build a better relationship between people and street arborization. This research concluded that street arborization is compromised by a lack of favorable and defined public policy for street trees planting in the city. The street arborization, which has not a planed policy, has been negatively influenced by the government changes. Due to this fact, big trees have been systematically cut from the streets, and being substituted by other small and medium species size, with less environmental effect, to attend the rules imposed by CPFL and population preconception. It was questioned the technical criterions adopted by 
Piracicaba Hall to authorize to cutting trees and the lack of a philosophic capacity and education among the workers responsible by the administration and management of street arborization. This education could make them to develop a greater feeling of affectivity and compromise with trees and arborization, which would be an example for the population. The research carried out with two different citizenships groups of Piracicaba showed that problems related with sidewalk broken by tree roots growth, "dirty" coming from the trees, such as leaves and flowers, interference in the city power net and culvert clogged have been the most problems noted by the population segment researched. However, discussion and reflections about the issue made by the population groups showed a predisposition to bring solutions that could not cause a sacrifice for the street arborization. Furthermore, items such as "beautiful" and "shade" were noted as the most important advantageous of street arborization. The participatory research, as a methodological resources used as an approach of the subject beside the studied groups, stimulated a rise in their environmental perceptions, bringing a feeling of appropriation and co-responsibility by their collective space, and a potential for thinking and acting about their reality. According to these results, it is recommended a formulation and an implementation of a public policy to increment and improve the quality of street arborization in the city, based on the evidence that there is not an "ideal tree" for street arborization. Through the broad education projects, there is a need of stimulating the development of feelings that take into account more respect and tolerance between trees and population. 


\section{INTRODUÇÃO}

\footnotetext{
"Creio que é Cícero que diz que, ao penetrar num bosque alto e cerrado, a presença de uma deidade se manifesta a você. Há bosques sagrados por toda parte. Lembro-me de ter ido a uma floresta, quando menino, e ficar reverenciando uma árvore, uma enorme e velha árvore, enquanto pensava: 'Ah, o que você conheceu, o que você tem sido!' Acho que essa sensação da presença da criação é uma tendência básica do homem. Mas hoje vivemos em cidades. É tudo pedra e rocha, manipuladas por mãos humanas.

Você vive outro tipo de realidade quando cresce lá fora, no meio da floresta, ao lado dos pequenos esquilos e das grandes corujas. Todas essas coisas estão ao seu redor como presenças, representam forças, poderes e possibilidades mágicas de vida que, embora não sejam suas, fazem parte da vida e lhe franqueiam o caminho da vida. Então você descobre tudo isso ecoando em você, porque você é natureza".

Joseph Campbell - O Poder do Mito
}

\subsection{Apresentação}

A idéia de trabalhar com o tema "arborização urbana" nasceu de uma inquietação pessoal ante os cenários desprovidos de árvores que encontrei em cidades onde residi e por onde passei no estado de São Paulo. Conheci a cidade de Piracicaba num dia de intenso calor há alguns anos atrás.

Procurando casa para alugar, desejei uma com quintal e de preferência com algumas árvores plantadas nele, um gramado, enfim, um pouco de espaço verde e sombra para meu filho pequeno. Depois de visitar uns cinqüenta imóveis na região central e em alguns bairros da cidade, consegui localizar apenas três casas com as características procuradas. A que escolhi tinha uma árvore no quintal e outra na calçada da rua, eram duas Sibipirunas completamente sufocadas com a cimentação a envolverlhe toda a região do colo.

Por muitos lugares onde passei em minha busca, observei jardins cimentados até o colo das plantas, quintais completamente impermeabilizados, paisagens áridas, tristes, 
ofuscantes... Deparava-me continuamente com tocos de árvores nas calçadas, quadras e ruas inteiramente inóspitas, sem a presença de uma mancha verde a suavizar a paisagem.

Por vezes, presenciei cortes de árvores em minha vizinhança, e angustiava-me com a mudança brusca de cenário. Ontem a sombra, o verde, o frescor e a alegria; hoje o sol escaldante, o concreto ofuscante, a tristeza...

Certo dia, em meio à minha pesquisa, obtive um relato espontâneo de uma vizinha. Ela estava eufórica porque a casa ao lado - a única arborizada de toda a vizinhança, e talvez de todo o bairro - fora vendida para um sindicato patronal, cuja primeira providência foi derrubar todas as árvores de um quintal de $700 \mathrm{~m}^{2}$, incluindo jabuticabeiras, palmeiras, goiabeiras, mangueiras, arbustos ornamentais, etc. etc.

Ao som angustiante da moto-serra, que começava seu trabalho já às $6 \mathrm{~h}$ da manhã, esta vizinha viu-me observando a destruição praticada em frente à minha casa, e veio abordar-me, como que esperando encontrar cumplicidade para sua euforia. Relatout me uma série de fatos relacionados à escuridão proporcionada pelas árvores à sua residência, e a ocasião em que uma tempestade inundou sua casa pois a calha estava entupida pelas folhas das três Sibipirunas da calçada de seu vizinho que gostava de árvores.

Falou ainda dos "inconvenientes" pássaros atraídos pelas árvores, que faziam ninhos em suas samambaias de metro, única "flor" da qual ela gostava. Para isso ela já tinha adotado um método a fim de "judiar dos pássaros, esperando que eles fizessem seus ninhos, e quando já tivessem botado dois ovinhos, os destruía, com ninho e tudo?'... Que origem teriam tais atitudes para com esses pobres seres da natureza?!...

Nasci e vivi até meus dezoito anos em uma cidade, que hoje tem cerca de cem mil habitantes, situada no noroeste do estado do Paraná. Cidade jovem, pouco mais de 40 anos, tem largas avenidas repletas de exuberantes Flamboyants, Sibipirunas, Grevilhas, Chapéus-de-sol e toda espécie de árvores grandes, pequenas ou médias. De tão verde, mais parece uma floresta! Hoje, depois de tantos anos vivendo em meio à outras paisagens, reconheço isso.

Minha inquietação transformourse então num desafio: procurar desvendar o que está por trás dessa "desvalorização" da árvore no ambiente urbano de uma cidade como 
Piracicaba. Fui buscar no campo da Educação Ambiental ferramentas que permitissem entender um pouco o que provocaria esse fenômeno.

Estaria o elemento "árvore" associado à problemas advindos de falhas de planejamento da arborização urbana da cidade? Como é administrada esta arborização? Existem políticas públicas voltadas à melhoria da arborização urbana em Piracicaba? E por outro lado, quais seriam as reais necessidades de moradores em termos de arborização? Quais os problemas causados pelas árvores do calçamento viário? Qual a sua percepção sobre o tema? Como aproveitar o momento da pesquisa para estimular ações?

Procurei inicialmente, realizar uma investigação teórica sobre alguns temas relacionados, buscando fundamentar uma visão mais geral sobre o problema, o que ajudou a compor a conclusão dessa dissertação. Para isso, explorei, ainda que timidamente, campos como o da filosofia, da sociologia, da psicologia social e da arborização urbana propriamente dita, complementando-os com leituras da educação ambiental. Essa multirreferencialidade exigida pelo tema não é fácil de ser explorada, primeiramente pela minha pouca maturidade científica, e em segundo lugar por tratarmos aqui de uma dissertação de mestrado, onde desde o início depara-se com uma forte pressão por objetividade e rapidez. No entanto, reconheço a importância de um aprofundamento maior no campo dessas ciências, e talvez até de outras que não puderam ser exploradas. Buscar respostas para os questionamentos que apresento aqui é um exercício que poderia ocupar toda uma vida.

$\mathrm{Na}$ pesquisa de campo realizei uma investigação sobre o gerenciamento e administração da arborização urbana na cidade, particularmente da arborização de calçadas, procurando mais que quantificar, captar idéias, opiniões e fatos que colaboram para a situação atual da arborização viária da cidade.

Apresento ainda os resultados de uma pesquisa participativa realizada com dois grupos de moradores da cidade, que buscou captar sua opinião a respeito do tema, compreender os valores e as necessidades que permeiam sua relação com as árvores de rua, e além disso, observar os efeitos do tipo de pesquisa adotado. 
Deixo claro que minha intenção ao analisar criticamente a situação da arborização viária da cidade não é a de apontar culpados, e sim compreender quais mecanismos poderiam ser utilizados para melhorar o quadro hoje existente. Espero desta maneira, dar minha contribuição pessoal, ainda que pequena, para ajudar a encontrar caminhos que tornem nossa existência de seres humanos urbanos, mais bela, feliz e harmoniosa com essa tal "Natureza", hoje tão agredida, mutilada e ignorada..

\subsection{A árvore milenar}

Existe na SP 330, no Município de Santa Rita do Passa Quatro/SP, o Parque Estadual de Vassununga. Nele está abrigado um Jequitibá Rosa (Cariniana legalis), com idade estimada de 3.000 anos.

Para os mais sensíveis, descobri-lo e estar próximo a ele chega a ser uma experiência mística. Impossível não sentir o coração emocionado e a mente girando ante o esforço de imaginar tudo que esse Jequitibá já presenciou nesta incrível jornada de séculos e milênios. Herói, sobrevivente de uma colonização desmatadora e devastadora, de ciclos e ciclos de culturas agrícolas, de incêndios florestais...

Impossível não reverenciá-lo. Um respeito quase filial aliado a um sentimento de profunda admiração somam-se à súbita noção da efemeridade de uma existência humana.

Impossível não sentir a dimensão sagrada que há neste incrível ser vivo de 3.000 anos.

Existe lá uma visitação pública bem expressiva, o que tem levado aos técnicos responsáveis pela manutenção do parque um receio muito grande quanto à continuidade dessa existência milenar do Jequitibá Rosa. De fato, é possível verificar nele sinais perturbadores dessa visitação, como por exemplo, pedaços de seu majestoso tronco feridos porque alguém quis levar para casa uma lembrança sua, retirando um pedaço da casca. Existe também um intenso pisoteio ao seu redor, o que expõe suas raízes ao perigo da compactação do solo. 
Será que a noção do "sagrado" que há nessa árvore chega a alcançar muitos dos corações e mentes que o visitam? Será que essa forte ligação com o passado que ele nos traz é percebida ou sentida pela maioria, mesmo que de modo fugaz?

Se a resposta for sim, talvez seja possível acreditar que o ser humano ainda não esteja totalmente escravo da frieza e da insensibilidade que lhe parecem ser tão característicos neste início de século XXI. Creio que as raízes de todo o mal que há na terra estão fincadas nestes dois tipos de sentimentos, que paradoxalmente poderiam ser descritos como "ausência de sentimentos".

Talvez fosse possível modificar hábitos e atitudes profundamente enraizados em nosso cotidiano através do resgate dessa sensibilidade latente, que precisa de alguma forma aflorar e tornar mais emocionante nossa relação com nossos irmãos da Natureza e também com nossos irmãos de espécie.

Se o "emocionar-se" diante de uma árvore é possível para grande parte de nós homens e mulheres deste terceiro milênio, então pode-se sonhar com dias melhores, onde se pensará muitas vezes antes de se sacrificar uma árvore da rua por futilidades como a quebra de uma calçada de cimento, por sujar as ruas com suas lindas e coloridas flores e folhas, esconder fachadas comerciais, ou por quaisquer outros motivos que nosso vão egoísmo possa produzir.

$\mathrm{O}$ respeito para com a árvore da rua será então, apenas um dos sinais de uma mudança maior, de valores e atitudes, de respeito e reverência pela vida em si. 


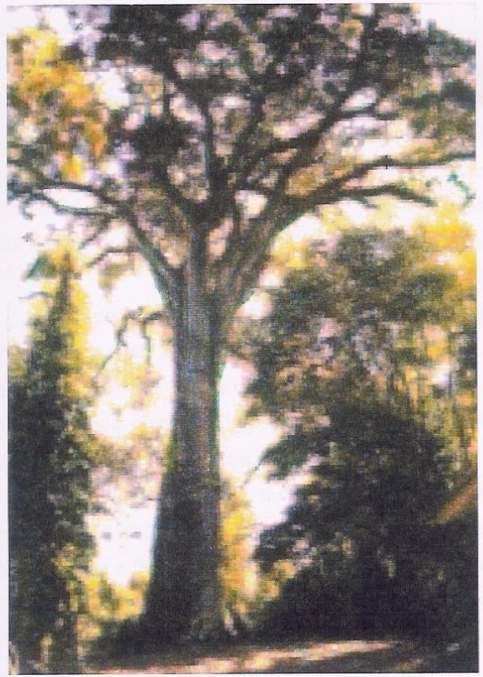

Fonte: site http://www.netsite.com.br/srpq/jequitiba.htm

Figura 1 - Jequitibá Rosa de 3.000 anos - Santa Rita do Passa Quatro/SP 


\subsection{Piracicaba e sua arborização}

Fundada no século XVIII, Piracicaba, cujo nome significa "lugar onde o peixe pára ou fica" na linguagem indígena, foi a primeira cidade brasileira a ter luz elétrica, graças ao empenho de Luiz de Queiróz, idealizador e criador da ESALQ, que também "mandava arborizar ruas e praças da cidade, introduzir novas culturas e presenteava os amigos com mudas de plantas exóticas" (Prefeitura do Município de Piracicaba, 1988, p. 20)

De acordo com o IBGE (Censo 2000) a população do município é de 328.312, sendo que deste total, 11.794 pessoas habitam a área rural, 316.518 pessoas compõem sua população urbana e 264.233 moram na sede municipal. A cidade está situada a 540 metros de altitude, com latitude de $22^{\circ} 42^{\prime} 30^{\prime \prime}$ e longitude $47^{\circ} 38^{\prime} 00^{\prime \prime}$, possuindo clima temperado com predominância seca.

Cidade antiga e de passado histórico, Piracicaba conta hoje, na virada do milênio, com 234 anos de idade, e como a grande maioria das cidades antigas do estado de São Paulo, sofre com a falta de um planejamento urbanístico moderno e mais coerente com as necessidades impostas pela expansão de suas áreas ocupadas. A arborização urbana mostra-se inadequada e insuficiente, o que contrasta com os problemas ambientais que afetam sua população, como por exemplo as doenças respiratórias causadas por materiais particulados em suspensão que poderiam ser retidos ou filtrados por uma arborização urbana mais abundante.

Seu índice de área verde é de apenas $3,6 \mathrm{~m}^{2} / \mathrm{hab}$ (índice oficial divulgado pela SEDEMA, em resposta à ação civil pública 992/97). Para este cálculo foram considerados os verdes provenientes das praças, áreas verdes de uso público, parques, cemitérios e parte da área da ESALQ, não sendo computados os jardins de representação, o verde viário e as áreas verdes particulares. De acordo com a SODEMAP (Sociedade de Defesa do Meio Ambiente de Piracicaba) a porcentagem de cobertura vegetal do município é de apenas 2,5\%, um dos índices mais ineficientes do estado. Esta entidade considera que o município deveria ter no mínimo $20 \%$ de 
cobertura vegetal (Jornal de Piracicaba, 29/01/1996, Apêndice 01). A própria Lei Orgânica Municipal, disciplina que Piracicaba deve atingir o índice de $10 \mathrm{~m}^{2} / \mathrm{hab}$.

Existem diversas definições para estes índices e diferentes formas ou metodologias para determiná-lo, o que origina discrepâncias consideráveis entre os índices de área verde de diferentes cidades, e por isso é complicado traçar comparações entre eles. Porém, como são a única referência disponível, não há como deixar de utilizálos como parâmetro ou referência, uma vez que um índice é apenas um indicador, e deve ser utilizado com bom senso.

De acordo com Bianchi e Graziano (1992) citando Milano e Disperati (1987) e Cavalheiro (1982), a Alemanha propõe como ideal o índice de $13 \mathrm{~m}^{2} / \mathrm{hab}$, e a Associação Nacional de Recreação dos Estados Unidos recomenda 28 a 40m²/hab.

A literatura da área nos mostra que outras cidades como Curitiba, Maringá e Vitória por exemplo, apresentam índices de área verde da ordem de 50,15 m2/hab, $20,62 \mathrm{~m}^{2} /$ hab e $82,7 \mathrm{~m}^{2} / \mathrm{hab}$, respectivamente (Milano,1992). Este autor discrimina estes índices da seguinte forma: em Curitiba, $9,55 \mathrm{~m}^{2}$ eram originários de áreas verdes públicas, enquanto os restantes 40,6 $\mathrm{m}^{2}$ correspondem a áreas particulares; em Maringá 13,92 $\mathrm{m}^{2}$ tinham origem na arborização de ruas, e apenas 6,69 $\mathrm{m}^{2}$ nas áreas verdes públicas, e em Vitória, a arborização de ruas contribui com 2,62 $\mathrm{m}^{2}$, praças e pequenos parques com $1,88 \mathrm{~m}^{2}$, áreas verdes particulares contribuem com 46,42 $\mathrm{m}^{2}$ e as unidades de conservação tradicio nais com 31,78 $\mathrm{m}^{2}$ (Milano, 1992, p.12).

O projeto "Piracicaba 2010" produzido pela Prefeitura Municipal de Piracicaba no ano de 2000 avalia que

"as áreas verdes do município são insuficientes, e de maneira geral, as áreas implantadas como sistema de lazer - para uso da comunidade - estão irregularmente distribuídas. A área central concentra as praças mais antigas, os Parques do Mirante e da Rua do Porto, os quais apresentam uma manutenção precária. Quanto à área periférica da cidade, não houve uma política preocupada com a cobertura vegetal, especialmente com a implantação das áreas de lazer. Percebe-se também a existência em determinadas regiões (zonas Norte e Sul principalmente), de áreas 
demarcadas como verdes mas que foram ocupadas por outros equipamentos urbanos. Com relação às áreas urbanas situadas às margens dos rios e ribeirões, constata-se um alto índice de degradação em função da deposição de lixo, entulho e ocupação irregular, ao invés de estarem devidamente protegidas com vegetação nativa.

Não há um planejamento de arborização de calçadas e substituição de espécies, fato agravado pela existência de espécies inadequadas onde a arborização existe, constituindo-se em grande desafio a ser superado" (Projeto Piracicaba 2010 Prefeitura Municipal de Piracicaba) ${ }^{1}$.

Atualmente, a cidade enfrenta, na época de estiagem, sérios problemas com a fuligem gerada pela intensa atividade de queima da cana-de-açúcar nos arredores e sofre com as altas temperaturas do verão, sendo estes problemas agravados pelo fato de Piracicaba situar-se em uma região deprimida, rebaixada por erosão e entre as terras altas do Planalto Ocidental (Ranzani, 1976), o que cria uma espécie de ilha climática que favorece os fenômenos apontados acima.

Talvez pelo desconhecimento das vantagens e benefícios das árvores urbanas, a cidade as vem eliminando de suas ruas ao longo do tempo, criando cenários inóspitos e desoladores na paisagem.

O empobrecimento da arborização viária de uma cidade como Piracicaba é um fenômeno que pode ser parcialmente entendido e explicado na pesquisa de seu histórico, políticas públicas, gerenciamento e orientações técnicas, porém a cultura, os hábitos e o nível de informação do povo deste lugar são alguns dos principais fatores a conduzi-lo.

\footnotetext{
${ }^{1}$ Informação obtida através do site http://www.piracicaba2010.com.br/Toptextos/oqueeh.htm acessado em 07/11/2001.
} 


\subsection{Objetivos}

- Investigar o estado da arborização viária, que é um segmento da arborização urbana, em Piracicaba, em termos de administração pública e gerenciamento, legislação e ações educativas, procurando conhecer a opinião da equipe técnica envolvida na questão;

- Compreender os anseios e necessidades de um segmento de sua população, os motivos que a levam a olhar o elemento "árvore" com preconceito ou de maneira negativa, motivando-a a desejar e solicitar os cortes sucessivos atualmente praticados. Tentar perceber quais fatores poderiam estimular mudanças de atitude, ou seja, quais elementos poderiam ser utilizados em campanhas educativas visado o resgate de um relacionamento melhor entre a população e as árvores viárias;

- Aproveitar o momento da pesquisa para provocar uma reflexão sobre o assunto e associá-lo a um processo educativo, através de uma metodologia participativa, e com técnicas diversificadas;

- Estudar os efeitos da utilização da pesquisa participativa nos grupos pesquisados, contribuindo desta forma, para a avaliação de metodologias empregadas no campo da educação ambiental;

- Contribuir para a melhoria da qualidade da arborização e urbana e do meio ambiente na cidade de Piracicaba. 


\section{REVISÃO DE LITERATURA}

\subsection{Dos bosques sagrados à arborização urbana}

\subsubsection{Simbologia e significados das árvores na história}

As árvores estão presentes na história dos seres humanos até a mais remota lembrança de passado que possamos alcançar. São os elementos naturais mais evidentes do planeta. Se hoje elas ainda são festejadas em dias comemorativos especiais, como o "Dia da Árvore", no passado simbolizavam vida, liberdade, conhecimento, sabedoria.... e faziam parte de rituais da natureza, ritos religiosos e celebrações entre todos os povos da história.

"O culto à árvore é espontâneo, imemorial e universal. Não há grupo humano que o não tenha praticado. É um decreto do fetichismo primordial de nossa espécie e se fundamenta no crescente afeto para com nossa primeira casa providencial, que é uma fronde. As mais diversas motivações nos impeliram para a cultura progressiva desse sentimento: a utilidade geral, a beleza da forma, a raridade, agasalho, sombra, adorno, o socorro dos frutos, o impacto emocional das floradas, a vinculação histórica à pessoas ou coletividades, tudo converge para despertar o nosso apego e veneração para esses verdadeiros templos verdes que o mundo nos oferece." (Schama, 1996, p.235).

"Sacerdotisas", "guardiãs", "instrutoras”, as árvores já foram consideradas seres sagrados, elos de união entre humanos e natureza.

Schama (1996, p.222-223) relata que os cultos da árvore já estiveram "disseminados por toda a Europa bárbara, dos litorais célticos do atlântico, na Irlanda e na Bretanha à Escandinávia, aos Bálcãs no Sudeste e à Lituânia no Báltico’'. O autor retrata também 
a presença incômoda desses rituais para a igreja Católica daquela época, que os considerava atos de idolatria e mandava destruir árvores objetos desses cultos. Fala sobre o velho culto romano da morte de Átis, em que um pinheiro simboliza a figura desse deus e todo ano uma celebração relembrava o sacrifício e autoflagelação de Átis, marcando o início da primavera.

O simbolismo arbóreo fazia parte de todas as religiões, estando o ciclo de vida, morte e regeneração de uma árvore, bem como seus órgãos e estruturas, simbólica e significativamente relacionados com aspectos da vida e da morte para o ser humano. Relembrando algumas vertentes religiosas Schama (1996) descreve:

"Mesmo uma lista sumária incluiria o haoma persa, cuja seiva conferia a vida eterna; o Kien-mou chinês, a Árvore da Vida que, com 100 mil côvados, vicejava nas encostas do paraíso terrestre de Kuen-Luen; a Árvore da sabedoria budista, de cujos quatro galhos fluem os grandes rios da vida; o lótus muçulmano, que assinala a fronteira entre o entendimento humano e o reino do mistério divino; Yggdrasil, o grande freixo nórdico que, com suas raízes e tronco, sustenta a terra entre o hades e o céu; as árvores cananéias consagradas a Astarte/Ashterah; os carvalhos gregos dedicados a Zeus, o loureiro a Apolo, o mirto a Afrodite, a oliveira a Atena; a figueira, sob a qual a loba amamentou Rômulo e Remo e, naturalmente, o fatal bosque de nemi, consagrado a Diana (e estudado por Frazer), onde o sacerdote guardião caminhava nervoso por entre as árvores, esperando o matador que sairia das trevas para sucedê-lo num ciclo interminável de morte e renovação" (Schama 1996, p.223).

Schuler (1995, p.101) lembra da figura bíblica de Adão que ao escolher alimentarse, contra a vontade divina, da Árvore do Saber, não alcançou a Árvore da Vida, conhecendo então o "bem e o mal, o trabalho e a morte, o penoso caminho da história".

$\mathrm{Na}$ história de Cristo a árvore também exerce um papel muito importante “... nasceu num estábulo de madeira, a mãe era casada com um carpinteiro, ele foi coroado de espinhos e pregado na cruz" (Schama, 1996, p.225). Árvores foram utilizadas simbolicamente em suas parábolas e no "Monte das Oliveiras" orou e foi crucificado.

No contexto das religiões orientais temos a famosa árvore da "iluminação" de Sidharta Gautama, o Buda, que passou seis anos peregrinando em busca de uma resposta para o sofrimento humano, procurando-a na filosofia dos brâmanes, no ascetismo severo e contemplativo. "Tudo em vão, nada lhe oferecia uma resposta satisfatória. 
Finalmente, sentou-se sob a árvore de Bodhi (um tipo de figueira, a Ficus religiosa) e, meditando, encontrou a Verdade. Alcançou a iluminação e foi chamado de Buda ('aquele que despertou')". (Hock e Mendoza, 2000, p.57)

Para as tradições esotéricas, o próprio corpo humano guarda uma simbologia estreitamente relacionada à árvore. Existe a árvore que representa o sistema nervoso, sendo sua raiz, o cérebro, e a árvore que representaria todo o sistema circulatório, sendo sua raiz o coração. Segundo essas tradições, estas duas árvores seriam responsáveis pelo governo da vida humana, a mente e o coração. (Aveline, 99, p.53)

O mapa de nossas origens e ancestralidades é mostrado pela árvore genealógica.

A famosa "Árvore de Natal" tornou-se objeto de culto e comemoração, marcando a principal festa do Cristianismo.

A simbologia das árvores expressou-se também através das artes e da arquitetura, onde no século XVII "igrejas e faróis são construídos à semelhança de grandes árvores, imensos carvalhos..." (Schama, 1996, p.242) . O autor traça comparações entre a nave de uma catedral gótica e uma alameda de árvores.

Soares (1998, p.192) citando artigo de E. Iloviare, lembra que na França revive uma tradição dos tempos da Grande Revolução, onde as árvores, símbolos da liberdade para o povo francês, são plantadas no início da primavera, representando a vida que desponta após o rigor opressivo do frio do inverno, e assim a alegria de viver livre e a esperança de dias melhores são renovadas.

Brown (2001, p.93-94) chama de "metamorfose", "metáfora", "transubstanciação", ou simplesmente o ato de "tornar uma coisa em outra" a transformação de algo em símbolo, descrevendo a maneira como poetas, pensadores e filósofos de todos os tempos se utilizaram da simbologia da árvore para sondar os mistérios da natureza humana. "Metamorfose em árvore. Uma queda para o estado da natureza. O espírito, a essência humana, se esconde enterrado no objeto natural”. Assim, segundo este autor, Shakespeare, Goethe, Ovídio, Virgílio, Vico, Petrarca, Freud, Karl Marx, Schiller utilizaram-se intensamente da metáfora da árvore em suas obras.

Para Schama (1996), as árvores são mitos, elos de ligação entre presente e passado: 
"Na teia de mitos que assim vai se formando vamos, aos poucos, reconhecendo imagens e associações familiares. Resíduos de um passado agreste vão emergindo, aqui e ali, na paisagem urbana de nossas cidades. Passamos a enxergar velhos cenários com novos olhos e a reconhecer quanta memória acumulada pode estar oculta na paisagem mais trivial'. (Schama, 1996 p.01)

A presença de árvores nas cidades traria portanto, nas palavras deste autor, "resíduos de um passado agreste", capaz de religar-nos com imagens e significações do passado. 'Não que seja fácil estabelecer os limites entre o agreste e o cultivado ou entre o passado e o presente. Quer escalemos as encostas, quer perambulemos pelas matas, nossa sensibilidade ocidental carrega um fardo de mito e lembrança" (Schama, 1996, p.569). O autor lembra que Thoreau "também viveu disso" ao dirigir-se ao "imponente pinheiral, vendo os raios dourados do sol poente 'passeando pelos caminhos da floresta como se estivessem num salão nobre'. Conscientemente ou não, estava lembrando a antiga tradição que considerava a floresta uma câmara sagrada" (Schama, 1996, p.569).

Thomas (1933) descreve a importância da árvore para os ingleses do século XVII:

"Nesse movimento, hoje tão familiar a nós, de preservação das árvores, independentemente de suas conseqüências econômicas, podemos ver muitos fatores: entre eles, considerações de planejamento, o desejo de conforto e a sensação de que as árvores são intrinsicamente belas. Entretanto, as pessoas queriam preservar as árvores não somente devido a sua aparência mas também àquilo que elas simbolizavam. Os homens amavam suas associações, sua antiguidade, seu vínculo com o passado. Um anelo de continuidade, um convite à imortalidade familiar e uma tendência a investir as árvores de atributos humanos foram fatores importantes. Assim como os homens tratavam com carinho os animais de estimação por serem projeções deles mesmos, também preservavam as árvores domésticas, por representarem indivíduos, famílias e, no caso do carvalho britânico, a própria nação. Talvez Durkheim se equivocasse ao sugerir que, adorando a Deus, os homens estavam realmente adorando a sociedade. No entanto, ele estaria muito mais perto da verdade se afirmasse isso a respeito do culto às árvores." (Thomas, 1933, p.266) 


\subsubsection{Queda do paraíso}

Atualmente, ao contrário do que ocorreu no passado, as árvores parecem estar desmitificadas e despidas de simbologia.

Algumas possíveis e teóricas origens desta desmitificação poderiam ser encontradas em Thomas (1933, p.28), onde se descreve: "Desde os tempos dos anglosaxões, a Igreja Cristã na Inglaterra colocou-se contra o culto das nascentes e dos rios. As divindades pagãs do bosque, da corrente e da montanha foram expulsas, deixando assim desencantado o mundo, e pronto para ser formado, moldado e dominado" falando sobre uma corrente de pensamento que atribui a exploração ocidental da natureza ao legado religioso característico da Europa, que conferia ao homem supremacia sobre todos os seres e elementos da Natureza.

Mais adiante, o mesmo autor cita Karl Marx, para quem "hão foi sua religião, mas o surgimento da propriedade privada e da economia monetária, o que conduziu os cristãos a explorar o mundo natural de uma forma que os judeus nunca fizeram; foi aquilo que ele chamou 'a grande influência civilizadora do capital' que finalmente pôs fim à 'deificação da natureza" (Thomas, 1933, p.29). Este autor fala de um tempo, no início do século XVII na Inglaterra, em que os bosques e matas foram substituídas por campos de cereais e pastagens, e as árvores eram tidas como elementos contrários ao processo civilizatório devendo ceder lugar aos elementos de uso e interesse mais imediatos para a vida.

Deve-se acrescentar que o simbolismo atribuído às plantas e arbustos pela população foi condenado não só pela Igreja, mas também pela ciência. (Thomas, 1933, p.84).

Na verdade, os rituais para a chuva, o sol, as árvores, dos povos primitivos, denotavam uma postura de grande reverência pela Natureza e pela Vida, que se constituíam de muitos mistérios; mas em rossos tempos, a ciência já desvendou uma infinidade dos mistérios da natureza daquela época, e aos poucos fomos deixando rituais e mitos para trás. 
Fonte de inspiração, religiosidade, abrigo, alimento, madeira e garantia de sobrevivência para os seres humanos, aos poucos a árvore foi se tornando empecilho ao desenvolvimento e ocupação de novas áreas por uma população que aumentava progressivamente.

De símbolos sagrados, guardiãs, sacerdotisas, as árvores passaram a ser denominadas por uma série de nomes técnicos e científicos. Antes adoradas, respeitadas e veneradas pela sabedoria e mistério que as cercavam, hoje tornaram-se "objetos" incômodos para muitos seres humanos, sofrendo injúrias, depredações e mutilações, tratadas como seres inanimados e desprovidas de importância por muitas pessoas que vivem nas cidades.

Dissecamos seu xilema, seu floema, seus tecidos parenquimáticos e paliçádicos, demos nomes diferentes para cada tipo de folha, flor e fruto, classificamos suas raízes e formas de suas copas, identificamo-as sob diferentes famílias e sub-famílias, espécies e sub-espécies, gênero e reino, e no entanto perdemos o contato afetivo com as árvores. Deixamos de amá-las. Observa-se que a grande maioria das pessoas atualmente relaciona-se com as árvores de forma fria ou indiferente, quando não de maneira antagônica.

Onde teriam se escondido o encanto, a simbologia, o mito?... Será que estão para sempre enterrados, esquecidos, perdidos na corrente destes séculos dominados pela busca materialista, por religiões preconceituosas e por uma ciência racionalista ao extremo? Reaverão um dia, os humanos, o encantamento pela natureza, o respeito e a reverência pelas diferentes formas de vida?...

Refletindo sobre mitos, encontrei em Chopra (2001) a seguinte afirmação:

"durante séculos os seres humanos olharam no espelho da natureza e viram o reflexo de heróis, magos, dragões e cálices sagrados. O sagrado era real, uma fonte de poder supremo e nada podia existir, de um rio a um trovão, sem a ação de um deus. Hoje o espelho está embaçado. Nós sobrepujamos a necessidade de um deus do trovão ou de um herói do Olimpo. O que vemos então?...(...) Se é verdade, como diz a máxima poética, que 'Um toque de Natureza transforma o mundo inteiro em uma família', então um toque de mito torna o mundo inteiro sagrado. Em um mundo sem mitos fica faltando alguma coisa..." (Chopra, 2001, p.50). 
Para Hopper (2001), o mundo atual passa por uma "crise de imaginação", onde perdeu-se a proteção das estruturas de mito anteriormente aceitas, e sofremos "o que $o$ psicólogo Jung denomina 'um empobrecimento sem precedentes de símbolos'”, (Hopper, 2001, p.113). O autor cita uma forte afirmação do poeta Archibald MacLeish para quem:

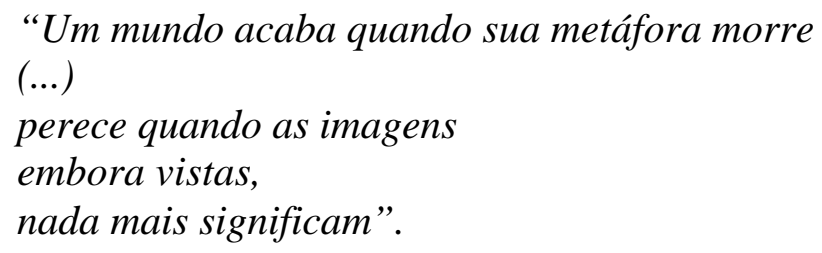

Para este autor, a "consciência do mito é de fato o elo que liga os homens e os conecta ao 'insondável Mistério’ de onde surgiram” (Hopper, 2001, p.115).

Portanto, mais que uma visão filosófica, a perda desta simbologia arbórea representa um sinal, ou talvez uma conseqüência, de uma crise mais profunda e sem precedentes na história da humanidade, e que tem nos levado à situação atualmente vivenciada de desarmonia dos seres humanos entre si e destes com a natureza, acarretando num mundo cada vez mais perturbado e caótico, que nos expõe ao risco da destruição total. Quando não se tem mais a noção do propósito original da vida, anda-se às cegas, vive-se sem sentido, através de falsas e perigosas buscas e aspirações. $\mathrm{O}$ consumismo desenfreado, a competição desumana, os fanatismos políticos e religiosos, os vícios, a busca do lucro à qualquer custo e a exploração irresponsável da natureza são alguns dos sinais desta desconexão do ser humano com sua origem. 


\subsubsection{Crise ambiental e emergência de novos valores}

Assistimos no final de século e milênio, ao agravamento dos problemas ambientais, sociais e econômicos no mundo todo e observamos que diversos setores da sociedade, finalmente, deram-se conta da necessidade urgente de se repensar modelos de desenvolvimento, estilos de vida, formas de pensamento, crenças, valores e comportamentos. Inquietações individuais estão tomando corpo, impondo-se e conquistando espaços coletivos cada vez maiores. Em poucas décadas, um movimento denominado "ambientalista" tomou conta do mundo, mobilizando governos e sociedade.

Segundo Pegoraro (1998, p.13) as atuais tendências do movimento ambientalista, foram precedidas por questões como a proteção da flora e da fauna, algumas formas de poluição e problemas relacionadas à água. Porém, "da inicial preocupação com a conservação da natureza, o ambientalismo adquiriu novas feições, predominando atualmente a busca de caminhos para se chegar a uma sociedade sustentável a partir, entre outros, do questionamento dos valores que norteiam as relações dentro das sociedades humanas e destas com os demais elementos do ambiente" (Pegoraro, 1998, p. 16).

Lago e Pádua (1989, p.36) avaliam que "a atual crise ecológica não se deve a 'defeitos' setoriais e ocasionais no sistema dominante, mas é conseqüência direta de um modelo de civilização insustentável do ponto de vista ecológico".

Para Guimarães (1998)

"Se há uma síntese possível para este final de século, ela pode ser caracterizada pelo esgotamento de um estilo de desenvolvimento que se mostrou ecologicamente predatório (no uso de recursos naturais), socialmente perverso (na geração de pobreza e desigualdade), politicamente injusto (na concentração do poder), culturalmente alienado (em relação à natureza) e eticamente censurável (no respeito aos direitos humanos e aos das demais espécies...) Em poucas palavras, a humanidade encontra-se ante a necessidade de transitar do estilo atual a um estilo de desenvolvimento sustentável que satisfaça as necessidades das gerações atuais sem comprometer a capacidade das gerações futuras de satisfazer suas próprias necessidades" (Guimarães, 1998, p.06). 
Assim, o conceito de sociedade sustentável passa a fazer parte do paradigma ambientalista, norteando planejamentos e ações entre diversos setores da sociedade.

Quando fala sobre a crise ambiental e novas posturas necessárias para reverter o quadro atual Leis (1998) traz algumas reflexões que também dão conta do caráter filosófico e espiritual da crise ambiental:

"A crise ambiental (pensada inclusive sem catastrofismos) não tem alternativas realistas fora de um ambientalismo sustentado em uma ética complexa $e$ multidimensional que recupere o sentido da fraternidade, o sentido espiritual da vida social e natural. A modernidade trocou a visão orgânica e transcendente do mundo clássico e medieval por uma visão dirigida apenas para a autopreservação. (...) A necessidade de desfazer a inversão moderna, representada pela emergência $e$ evolução de um ambientalismo multissetorial global de forte raiz ética e espiritual, deriva do caráter civilizatório da crise ambiental, afetando todas as dimensões da condição humana. A crise ambiental não é apenas um resultado indesejado e conjuntural, é um desencontro dos mortais com suas raízes..." (Leis, 1998, p.120).

Também LaChance (1996, p.31) trata desta crise como uma doença, uma "intoxicação crônica do planeta", falando do estilo de vida consumista e sem sentido que a produz, gerando "doenças secundárias" como a perda do contato funcional e autêntico com as tradições religiosas, o radicalismo, e vários outros distúrbios morais e espirituais. Segundo ele os sintomas dessa doença cultural é a falta de respeito pelos seres vivos e pelo próprio planeta. "Penso que a maioria das culturas perdeu suas ligações espirituais que as teriam guiado em direção a um respeito mais profundo em relação à multiplicidade e autonomia de todas as coisas vivas" (LaChance, 1996, p.24).

Para Gutierrez e Prado (1999, p.30) o paradigma emergente opõe-se à lógica racionalista que nega o sagrado e a subjetividade, que destrói a natureza e a vida em nome do desenvolvimento e do progresso, e esse novo paradigma pode levar o ser humano a redescobrir o "lugar que lhe corresponde dentro do conjunto harmonioso do universo" 


\subsubsection{Razão versus Sensibilidade}

Para Maffesoli (1998, p.189)

"os discursos e as mitologias não são senão maneiras complementares de exprimir uma mesma coisa: o retorno de uma concepção global do homem em seu ambiente natural e social. Assim, ainda que isso possa causar sobressaltos a alguns, convém pôr em ação, de modo paradoxal, uma 'sensibilidade intelectual' que seja capaz de dar conta da encarnação do mito em dado momento. (...) tal sensibilidade é bem mais importante que as querelas escolares acerca de temas abstratos, cuja inanidade se torna cada vez mais visível”

Segundo ele "o sensível" não é mais um fator secundário na construção da realidade social: "É preciso considerá-lo como elemento central no ato de conhecimento"(Maffesoli, 1998, p.189). Fala de uma 'Razão Sensível" que deveria vir em oposição à "Razão racionalizante" que domina nossos meios científicos e intelectuais e da importância de encontrar-se um "equilíbrio entre o intelecto e o afeto".

"Assim fazendo, à imagem do poeta, ele (o intelectual) se torna capaz de evocar aquelas idéias mobilizadoras, aqueles 'mitos encarnados' em ação na estruturação social" (Maffesoli, 1998, p.29).

Simón Rodríguez, citado por Gutierrez e Prado (1999, p.63-64) coloca o seguinte:

"O que não se faz sentir, não se entende, e o que não se entende, não interessa"

e os autores complementam:

"Se quisermos dar sentido ao que fazemos, antes de mais nada, devemos sentir e sentir com nossos sentidos. É evidente, em conseqüência, que o sentimento, a intuição, a emoção, a vivência e a experiência são esse norte que nos guiará com a idéia de construir um futuro a partir da realidade de cada dia" (Gutierrez e Prado, 1999, p.63-64) 
Estes autores afirmam ainda, que o sentimento, a emoção e a intuição são fundamentos da relação entre seres humanos e natureza, que devem, ao contrário do que vem sendo feito até agora, ser alimentados na construção de nossas vidas (Gutierrez e Prado,1999, p.44)

Em outras palavras, a humanidade encontra-se ante a necessidade e o desejo de percorrer o caminho inverso ao que foi percorrido até aqui, e no meio deste caminho reencontrar-se com sensibilidades e valores perdidos ou sufocados pelo cientificismo racional, por preconceitos religiosos, por regimes políticos "castradores" ou por quaisquer outras atividades humanas restritivas que a tenham levado ao estado atual.

Para Viana e Hoeffel (1998, p.68) a preocupação com o meio ambiente, aos poucos, vai passando a fazer parte do pensamento coletivo, porém não necessariamente ocorre com todas as pessoas, todos os grupos sociais, todos os setores econômicos ou em todos os países;

"os velhos modos de pensar e agir ainda são hegemônicos e, portanto, predominam como referência, mas a nova tendência já está consolidada com o novo devir. (...) o novo e o velho vão conviver na realidade social, o velho perdendo terreno $e$ legitimidade, o novo ampliando seu espaço, gerando formas de articulação, constituindo a nova legalidade e, por fim, tornando-se hegemônico na vida social" (Viana e Hoeffel, 1998, p.68).

Os autores citam Adorno (1986), ao refletir que a "incapacidade de amar, tem marcado nossa sociedade nos últimos tempos, culminando na frieza que em tudo penetra - nas relações pessoais e sociais, atingindo a ordem social que produz e reproduz a frieza."(Viana e Hoeffel, 1998, p.74).

E complementam citando Rubem Alves (1991):

"a questão decisiva não é a compreensão intelectual, mas o ato de amor. São atos de amor e paixão que se encontram nos momentos em que se fundam mundos(...) $E$ depois, quando se esvai o ímpeto criador (...) é que se estabelecem a gerência, a administração, a burocracia, a rotina, a racionalização, a racionalidade (..) $E$ a objetividade científica domina o espaço da educação e é assim que aprendemos a assepsia do desejo, a repressão do amor, a vergonha de revelar as paixões e as 
esperanças. Dizer os próprios sonhos? Contar as utopias construídas no silêncio? Quem se atreve?" (Rubem Alves citado por Viana e Hoeffel, 1998, p.74)."

Amar a árvore da rua, amar o rio que atravessa o bairro ou a cidade, amar a paisagem limpa e fresca... quando nós, humanos, reconquistarmos tais sentimentos em relação ao nosso ambiente e tivermos a coragem de expressá-los, muitos de nossos problemas se resolverão automaticamente. Por isso o despertar do "amor" deveria estar por traz, como meta, como ferramenta ou como objetivo de processos educativos realmente transformadores.

\subsubsection{Percepção da natureza na cidade}

As árvores, aparentemente, não representam mais elementos sagrados para os humanos urbanos deste início de século XXI; ao invés disso, trazem inúmeros inconvenientes de caráter prático para o seu cotidiano.

Ferrara (1993, p. 19) diz que "á transformação da cidade é a história do uso urbano como significado da cidade, sua vitalidade nos ensina o que o usuário pensa, deseja, despreza, a relação de suas escolhas, tendências e prazeres. A transformação da cidade é a história do uso urbano escrita pelo usuário, e o significado do espaço é o desenvolvimento daquela percepção"

Atualmente constata-se que existe nas cidades, uma preocupação excessiva em eliminar elementos e fatores que possam representar "sujeira" e trabalhos adicionais àjá tão sobrecarregada jornada diária de atividades da vida moderna. Quintais e passeios públicos cimentados, completamente impermeabilizados são sinais e conseqüências dessa preocupação. As árvores, principais elementos de ligação entre seres humanos e natureza, passam a disputar espaço na paisagem com outros elementos de caráter prático como postes, fiação elétrica e telefônica e calçadas. A natureza passa a ser percebida, quando percebida, como algo distante e separada da vida urbana. 
Pegoraro (1998) reflete que

"num mundo com preocupação crescente nos problemas de deterioração ambiental, sejam eles energéticos, poluição, plantas e animais em extinção, paisagens naturais ou produtivas, há uma grande propensão em passar por cima do meio ambiente onde vive a maioria das pessoas - a própria cidade. Isso faz o senso comum enxergar a cidade moderna como um lugar de energia barata, força econômica, alta tecnologia e uma negação da natureza; em resumo, a degradação ambiental" (Pegoraro, 1998, p.212).

E de acordo com Ferrara (1993, p.125)

"a sociedade de consumo, marcada por certa especialização técnica no campo de trabalho e, sobretudo pelo vintém poupado que permite o acesso, ainda que superficial, ao mundo do valor de posse, privatiza as aspirações coletivas e as centraliza na habitação e na tecnologia dos objetos, que isolam ao mesmo tempo que satisfazem. Desse modo a experiência coletiva, tão importante para as práticas associativas, é exterminada, não apenas nas longas horas destinadas ao trabalho, mas também na rua, nas praças, nos espaços comuns, na vizinhança, que deixaram de ser signos, perderam significados, na medida em que já não agasalham o cotidiano da ação construída coletivamente".

Desta forma, isolados no interior de suas habitações, concentrados na utilização de seus "objetos" e "distantes" da natureza, as pessoas deixam de utilizar-se dos espaços coletivos representados pelas ruas e praças públicas. A presença de árvores nestes locais passa a ser pouco notada e valorizada, a não ser que esta presença se constitua em algum problema. Por outro lado, a ausência da experiência coletiva descrita por Ferrara, leva o cidadão urbano a um individualismo solitário, isolando indivíduos, famílias e grupos. O bem-estar coletivo passa a ser sacrificado em detrimento do bem-estar individual e familiar. As árvores, que trazem transtornos a alguns, são eliminadas de muitos cenários urbanos, deixando de oferecer seus benefícios à toda uma coletividade.

Porém, utilizando-se de outra abordagem, Spirn (1947) vê a cidade como parte da natureza. O ciclo de energia, animais, ar, água, rios subterrâneos, jardins, ervas daninhas, tudo isso é natureza também. "Compreender a cidade como parte da natureza, projetando-a e mantendo-a de acordo com os ciclos e necessidades da natureza", 
segundo ela evitaria uma série de transtornos e calamidades com os quais convive-se atualmente.

Para esta autora

"os recursos oferecidos e as dificuldades impostas pelo sítio natural de cada cidade compreendem uma constante com a qual sucessivas gerações tiveram de tratar sucessivamente, cada uma de acordo com seus próprios valores e tecnologia. Civilizações e governos ascendem e caem; tradições, valores e políticas mudam, mas o ambiente natural de cada cidade permanece uma estrutura duradoura na qual atua a comunidade humana. O ambiente natural de uma cidade e sua forma urbana, tomados em conjunto, compreendem um registro da interação entre os processos naturais e os propósitos humanos através do tempo. Juntos contribuem para a identidade única de cada cidade" Spirn (1947, p.28).

\subsubsection{Participação e cidadania}

O planejamento, construção e gerenciamento dos espaços coletivos naturais ou produzidos artificialmente nas cidades, quase sempre têm sido realizados pelas administrações públicas, representadas por seus técnicos, legisladores e políticos. A população, de certa forma, acabou por acostumar-se ou acomodar-se aos cenários que lhe são apresentados ou impostos em seu ambiente urbano. Esta "perda" de poder efetivo sobre seus espaços, associada aos argumentos expostos no item anterior, acaba por afastá-la dos elementos naturais, tornando-a de alguma maneira, indiferente à eles. $\mathrm{O}$ resultado disso é a degradação ambiental vivenciada na atualidade e uma qualidade de vida cada vez mais desfavorável para os habitantes das cidades.

É claro que grande parte desta degradação não é provocada pelo cidadão comum, mas é patrocinada por empresas e indústrias em suas atividades poluentes e devastadoras, motivadas pelo interesse econômico capitalista. Porém, a postura passiva da população, acostumada a aceitar o que vem das esferas de poder, acaba por contribuir para criar condições favoráveis às atividades degradantes dos ecossistemas. Mas, 
admita-se que a outra parte desta degradação é mesmo realizada pelos próprios cidadãos comuns, de forma inconsciente, inconseqüente e indiferente.

Por outro lado, a atual crise dos recursos hídricos e energéticos, o aumento das carências sociais e dos serviços públicos e o agravamento dos problemas ambientais entre outros, evidenciam o fracasso dos atuais sistemas políticos e administrativos em gerir a sociedade de modo justo e equilibrado.

Na contra-mão desses fenômenos, uma nova corrente de forças vem tomando forma em esfera mundial. Ferreira (1998/1999, p.06) fala do ritmo acelerado das “transformações tecnológicas", de "uma gigantesca renovação científica", citando o "processo de globalização ou internacionalização do espaço mundial" e reflete que uma implicação imediata dessa nova realidade é o fortalecimento do espaço público comunitário, com estruturas de governo menos centralizadoras, como já vem acontecendo em alguns países altamente industrializados. Segundo ele esse fenômeno "reflete a evolução da democracia representativa para sistemas descentralizados e participativos" (Ferreira, 1998/1999, p.6).

Ainda segundo este autor

"os municípios passam a defrontar-se com uma situação grave que exige intervenções ágeis em áreas que extrapolam as tradicionais políticas na área urbana. Trata-se de amplos projetos de infra-estrutura, políticas sociais, programas de emprego e políticas ambientais que envolvam inclusive estratégias locais de dinamização das atividades econômicas. Esse quadro requer, em uma perspectiva de cidades sustentáveis, maior participação dos atores vinculados à problemática ecológica e a capacidade de incidirem sobre a definição de políticas públicas e do acesso direto à gestão do estado" (Ferreira, 1998/1999, p. 6 e 7).

Também Almeida et al. (1993, p.42) nos dizem que a "adoção do modelo de desenvolvimento, que contemple a questão ambiental, passa obrigatoriamente, pela democratização das decisões, de forma a permitir a participação da sociedade, garantindo acesso à discussão dos problemas e direito de vigilância no cumprimento das ações".

Para Bordenave (1985) 
“(...) a participação social e política é a luta das classes populares para que as classes dirigentes cumpram seu dever. (...) A participação não tem, pois, somente uma função instrumental na co-direção do desenvolvimento pelo povo e o governo, mas também exerce uma função educativa da maior importância, que consiste em preparar o povo para assumir o governo como algo próprio de sua soberania, tal como está escrito na Constituição. (...) Através da participação, a população aprende a transformar o Estado, de órgão superposto à sociedade e distante dela, em órgão absolutamente dependente dela e próximo dela" (Bordenave 1985, p.56).

Ainda, segundo Bordenave (1994, p.58) "a participação das pessoas em nível de sua comunidade é a melhor preparação para a sua participação como cidadãos em nível da sociedade global".

Falando sobre cidadania e participação, Barbosa (1995) analisa que a "questão maior, que está imbricada na temática da discussão de ambiente e qualidade de vida, é a questão da cidadania". Para ela "o entendimento do conceito de qualidade de vida, ou da forma como é encarada, deverá constituir-se da visão que o sujeito, enquanto participante de uma sociedade urbano-industrial, tem da sua própria vida, de seu ambiente social e do grupo ao qual pertence." A busca dessa visão segundo ela "se complementa com mapeamentos da realidade local (que será estudada), das formas de política participativa e do gerenciamento dos problemas existentes. Da mesma forma, a busca da cidadania como um processo em construção poderá se dar através da melhoria da qualidade de vida, fator que por si só impulsionará a participação coletiva" (Barbosa 1995, p. 206, 207) .

Franco (1995, p.10) fala de uma "Nova Política da Contemporaneidade", que surge na "ultrapassagem de uma perspectiva individual para a coletiva, quando o exercício da ética exige a prática da política e vice-versa". Para ele a combinação entre o "pessoal com o social, da pessoa com o planeta, da comunidade (local) com a humanidade (global)" é o segredo para a nova relação ético-política que constitui "humanidade". E complementa: 
"Ainda que pareça paradoxal, a volta ao local é um fenômeno acompanhante do processo de globalização atualmente em curso. 'Global' e 'Local' não constituem pólos de uma contradição irreconciliável, mas partes complementares de uma mesma tendência que brota do interior da crise do padrão civilizatório atual, que transcende a crise dos 'sistemas' capitalista e socialista" (Franco, 1995, p.11).

Gutierrez e Prado (1999, p.14) falam de uma "cidadania ambiental" que

"compreende as obrigações éticas que nos vinculam tanto à sociedade como aos recursos naturais do planeta de acordo com nosso papel social e na perspectiva do desenvolvimento sustentável". (...) "Se nós, seres humanos, somos, a partir de nossa cotidianidade, desarmonizadores, deveríamos ser atores da harmonia ambiental através do uso mais humano dos recursos naturais. Embora devamos lutar pelas macrossoluções, as quais correspondem aos governos, às empresas, às grandes entidades sociais, nossa preocupação imediata deve ser levantar as soluções que estão a nosso alcance e que estão fortemente marcadas por ações de sobrevivência e por uma melhor qualidade de vida. Trata-se, em sintese, de saber vincular os problemas ambientais e suas soluções com a vida cotidiana e com a busca daquelas relações harmônicas que nos levem a uma melhoria da qualidade de vida" (Gutierrez e Prado, 1999, p.32).

\subsubsection{A Presença das árvores nas cidades: origem e conceito de arborização urbana}

Mesmo estando presente na história da humanidade desde seus primórdios, a árvore adquiriu importância para os habitantes das cidades, somente no início do século XVIII, na Europa.

Lamentando o desmatamento e o empobrecimento da paisagem, uma parcela da população inglesa da época passa a valorizá-las, estimulando o seu plantio nas cidades. "As árvores, em outras palavras, eram agora cultivadas e queridas por simples amenidades" (Thomas, 1933, p.243).

Porém, para este mesmo autor, seria impossível afirmar quando começou o cultivo de árvores em cidades, pois desde os tempos imemoriais, grupos de árvores foram preservados perto de casas, fornecendo abrigo contra ventos e sombra no verão (Thomas, 1933, p.244). 
Franco(1997) fala da introdução das árvores nas cidades européias, ocorrido no período clássico barroco, como decorrência de uma evolução e requinte no modo de viver urbano daquela época, quando surgiram então, novos tipos espaciais, como o parque, a alameda, o jardim e o passeio arborizado.

A autora cita o trabalho de Olmstead, que inspirou não somente a criação de numerosos parques nacionais, nos Estados Unidos e em todo o mundo, como também seria responsável pela mudança no conceito de qualidade ambiental urbana, com a elaboração de vários parques nas cidades de Nova Yorque, São Francisco, Buffalo, Detroit, Chicago, Montreal e Boston. Segundo ela "o surgimento dos parques urbanos e a aspiração urbana ao verde acabou por inspirar a famosa criação de Ebnezer Howard, 'A Cidade Jardim', e seus conhecidos desdobramentos na história do urbanismo, os quais podem ser considerados como conseqüência do 'Parks Movement' " (Franco, 1997, p.83).

No Brasil, essas influências marcaram algumas reformas urbanas no início do século XX na cidade de São Paulo, com os projetos do Anhangabaú e do Parque Dom Pedro II, e da Barry Parker nos empreendimentos da Companhia City para os bairros jardins, especialmente os do Jardim América e Pacaembú (Franco, 1997, p.86).

Goya (1994, p.136) assinala que já no Brasil colonial de meados do século XVII, no período de ocupação holandesa e sob influência de sua cultura, na cidade de Recife são plantadas "centenas de palmeiras, romãzeiras, laranjeiras, figueiras e limoeiros ao redor dos Palácios de Boa Vista e Friburgo".

De acordo com Lima (1993)

"a prática de plantar árvores ao longo de ruas e praças iniciou-se no século XVII, com Luiz XIV, na França, e, depois estendeu-se por toda a Europa. Já no Brasil, existem dois cenários prováveis para o início da arborização urbana: um, mais antigo, no final do século XVIII, onde o arquiteto naturalista Antônio José Landi teria plantado muitas mangueiras pelas ruas da cidade de Belém/PA, com a finalidade de estudar e promover a adaptação da espécie ao novo ambiente; outro, no Rio de Janeiro, no início do século passado, época em que o plantio de árvores nas cidades, se difundia como nova exigência pelo mundo. Até esse período, além dos jardins comuns, raros e criados apenas nas cidades principais, a imagem urbana desconhecia árvores e canteiros nas vias e nos largos" (Lima 1993, p.5). 
Atualmente, com a consolidação de sua presença nas cidades, a arborização urbana tornou-se objeto de estudos de várias ciências, além de importante componente em planejamentos urbanísticos que levem em conta fatores ecológicos e ambientais.

Vários conceitos são criados a fim de classificar essa arborização e oferecer critérios para o seu planejamento.

Milano (1994, p.207) considera arborização urbana "o conjunto de terras públicas e privadas com vegetação predominante arbórea que uma cidade apresenta".

Lima (1993, p.4) cita Cavalheiro e Caetano (1984) para quem a arborização das vias públicas é composta pelos "espaços verdes integrantes de canteiros centrais ou laterais de vias urbanas, espaços verdes pequenos e isolados; bem como árvores isoladas e agrupadas elou fileiras destas que se encontram ao longo do sistema viário".

Para Sanchotene (1994, p.16) a arborização urbana pode ser composta pelo conjunto de vegetação natural ou cultivado na cidade, estando representada em áreas particulares, parques, praças, vias públicas e em outros verdes complementares.

Lima (1993, p.3) explica que "a arborização viária das cidades é um segmento da denominada 'arborização urbana' ou 'verde urbano' que, embora mais específico, mostra-se extremamente complexo e de muitas implicações nos dias atuais".

Souza (1994) avalia que a arborização de uma cidade pode ser abordada sob os pontos de vista referente a parques e praças e referente a ruas e avenidas. Para este autor, enquanto que em parques e praças há uma liberdade muito maior na utilização de espécies arbóreas que compõem os projetos ou "meras composições vegetais", em ruas e avenidas, o trabalho é mais complexo devido a diversos fatores, entre eles alguns de caráter subjetivo, "como preconceitos ou opiniões populares, a vontade ou critério de administração municipal, o eventual preparo técnico de seus executores, os problemas clássicos e universais da interferência das raízes das árvores com a pavimentação da copa e com a fiação aérea e não raro com a circulação de veículos" (Souza 1994, p. $67)$. 


\subsubsection{A importância das árvores nas cidades}

O conteúdo simbólico e espiritual associado às árvores desde os primórdios da humanidade, seu significado como elo de ligação entre seres humanos e natureza, a beleza e o frescor proporcionados por sua presença, retratam um pouco dessa importância para os habitantes das cidades.

Soares (1998) em seu livro "Verdes Urbanos e Rurais", fala poeticamente da importância da árvore nas cidades:

"Uma arborização correta e harmoniosa, ao mesmo tempo que espelha a cultura e o grau de civilização de uma cidade, constitui-se num dos mais sólidos elementos e sua valorização. Na beleza das frondes, às vezes veneráveis, que revestem ruas e avenidas, nas sombras acolhedoras, no verde das folhagens ou magnificiência das florações que periodicamente realizam as mais surpreendentes e agradáveis rotações cromáticas da paisagem, residem os vínculos afetivos que enlaçam os habitantes, de qualquer condição, com sua cidade familiar" (Soares 1998, p.30).

Não obstante essa visão simbólica e afetiva, a ciência enumera muitos outros benefícios ecológicos e ambientais que as árvores proporcionam às cidades.

Há muito tempo atentas a estes benefícios, cidades situadas em países desenvolvidos como EUA e Canadá, encontram na arborização urbana recursos para melhorar a qualidade de vida de seus habitantes e solucionar problemas ambientais.

Já em 1947, nos Estados Unidos, Spirn, em seu livro "Jardins de Granito" traça estratégias para a melhoria da qualidade do ar, o aumento do conforto e a conservação de energia para o aquecimento e acondicionamento do ar através da cidade. Entre estas estratégias está "explorar o potencial do plantio de árvores em larga escala dentro da cidade para diminuir o efeito de ilha de calor no verão e mitigar os problemas dos ventos" (Spirn, 1947, p.101).

Com o agravamento da crise ambiental, o efeito estufa e o aquecimento do planeta passam a fazer parte das preocupações do cidadão urbano. Assim, as árvores e os elementos naturais revestem-se de importância ecológica e ambiental no ambiente das cidades, tão artificializadas em suas estruturas e sistemas.

Moll (1991) nos fala dos impactos negativos que a engenharia urbana impõem sobre o meio físico, como a remoção da estrutura e da elasticidade biológica, retirando 
ar do solo, drenando a água das chuvas e substituindo áreas verdes por concreto. Segundo ele, as árvores fornecem "serviços" amortizadores do clima nas cidades, pois a remoção da cobertura arbórea "expõe os ciclos naturais ao 'curto-circuito' e a energia contida nesses ciclos é liberada, afetando negativamente o meio ambiente. Sem as árvores, as cidades tornam-se mais quentes e secas, a poluição agrava-se, os ventos tornam-se mais fortes, os problemas relativos à poeira agravam-se, o consumo de energia eleva-se e o ambiente urbano, como conseqüência, torna-se menos saudável e confortável à população" (Moll, 1991, p.335).

De acordo com Milano (1994) citando vários autores, alguns dos principais benefícios proporcionados pela arborização urbana são:

- "melhoria e estabilidade microclimática pela redução das amplitudes térmicas, redução da insolação direta, ampliação das taxas de evapotranspiração e redução da velocidade dos ventos;

- redução da poluição atmosférica pela biofiltração de gases poluentes e como anteparo de deposição de material particulado;

- redução da poluição visual e melhoria da paisagem tanto pela ação de anteparo visual como por constituir elemento especial de referência e estruturação do espaço urbano;

- redução da poluição sonora quer pelo seu efeito físico de anteparo à propagação do som como pelo seu efeito psicológico de proteção;

- oferta e valorização de espaços de convívio social, pela disponibilidade de praças, parques e jardins de uso público;

- valorização econômica das propriedades, pela agregação de valores indiretos de qualidade ambiental e paisagística aos imóveis;

- melhoria das condições de saúde física e mental da população, como conseqüência dos demais aspectos considerados" (Milano, 1994, p.209-210).

Sanchotene (1994, p.16) considera ainda, que a arborização urbana é importante também por "melhorar as condições do solo urbano, melhorar o ciclo hidrológico, reduzir as despesas com condicionamento térmico nos ambientes construídos, aumentar a diversidade e quantidade da fauna nas cidades, e por representar valores culturais da memória histórica das cidades".

Detzel (1994, p.50), acrescenta que as árvores e áreas verdes proporcionam estímulos à sensibilidade humana e que, "quando estabelecidas de forma adequada, 
geram empregos diretos e indiretos e propiciam a geração de divisas pelo considerável aumento de bens e serviços".

Para Cavalheiro (1994) os benefícios proporcionados pela arborização urbana podem ser classificados em estéticos e ecológicos, e assim os descreve:

Benefícios estéticos:

- "As árvores transmitem, através de seu 'habitus' noção de referência escalar para dimensões e espaços;

- elas caracterizam ruas, logradouros e por isso dão noção referencial para toda a cidade;

- alamedas, fileiras de árvore e árvores isoladas contribuem para delimitar espaços e representam de 'per si' vivência espacial;

- representam meio de orientação na cidade e nas ruas;

- marcam com sua copa, a terceira dimensão de espaços livres;

- pode-se, não só guiar oticamente as ruas e estradas com árvores, como também ressaltar cruzamentos e curvas;

- ruas marcadas oticamente com árvores possibilitam o cálculo de distância e pontos de perigo, e por isso contribuem com a segurança no trânsito.

Benefícios ecológicos:

- as árvores possibilitam rebaixamento de temperatura, através da fotossíntese, setorialmente de até 6 a $8^{\circ} \mathrm{C}$;

- rebaixamento da temperatura através da sombra;

- estabelecimento de circulação de ar, devido à diferença de temperatura;

- enriquecimento da umidade do ar, através da transpiração da fitomassa (300-400 ml/água/metro quadrado de área);

- embora somente pequena parte da pluviosidade precipitada possa ser interceptada e retida pela vegetação em ambientes urbanos, diminuem o escoamento superficial de áreas impermeabilizadas;

- diminuem a reflexão de luz solar;

- através da fotossíntese, consumo de gás carbônico, liberação de O2.

- Devido à fotossíntese e respiração filtra o ar retendo particulado sólido nas folhas;

- Diminuem a velocidade do vento em corredores formados pelas construções;

- Diminuem os ruídos urbanos;

- Ruas arborizadas transmitem sensação de bem-estar aos motoristas;

- Transmitem bem-estar psicológico em calçadas e passeios;

- Em locais de tráfego lento e em estacionamentos proporcionam sombra e sensação de relação espacial;

- Em dias quentes e abafados suas benesses são melhor percebidas e louvadas". (Cavalheiro, 1994, p.230) 
Lima (1993) cita Heisler (1974) e Lombardo (1985), segundo os quais já se detectou diferenças de 4,5 a 9,5 $5^{\circ} \mathrm{C}$ entre as áreas construídas e vegetadas do Parque Golden Gate, na cidade de São Francisco (EUA); e em São Paulo/SP, entre o centro e a área periférica, houve diferenças de temperatura superiores a $10^{\circ} \mathrm{C}$.

Em relação à qualidade do ar, Sattler (1992, p.24) cita Bernatzky, que mostra em seu trabalho que ruas bem arborizadas retêm até $70 \%$ da poeira em suspensão e que, mesmo na forma desfolhada das espécies decíduas, a eficiência ainda é de $60 \%$.

Sattler (1992, p.22) salienta que as árvores funcionam como bombas hidráulicas, absorvendo a umidade do solo e liberando-a na atmosfera. Recomenda que, para manter um adequado balanço térmico em áreas urbanas, seja mantido um índice de $30 \%$ de cobertura vegetal. Para este autor, índices abaixo de 5\% de cobertura vegetal, confeririam às cidades características semelhantes às do deserto.

\subsection{9 Árvores, ambiente urbano e pessoas: uma convivência delicada}

Se os moradores das cidades do século XVIII passam a valorizar as árvores no cenário urbano, a revolução industrial ocorrida logo após, vem perturbar essa relação. Para Mohr (1985, p.31), a maior parte das cidades encontra-se atualmente, imersa em grandes desequilíbrios ecológicos, climáticos e sociais e ausência de espaços naturais. Soma-se aos impactos da revolução industrial, a crescente expansão da população urbana, quase sempre ocorrida de forma desordenada e carente de planejamento.

Para Bueno ${ }^{2}(2000)$, todos os benefícios proporcionados pela arborização urbana têm um custo, pois o porte das árvores é que determinará a área de sombra, e o "atrativo

${ }^{2}$ Bueno, O.C. "Arborização e conflitos". In: I Seminário sobre Arborização Urbana: das NecessidadesTécnicas à Educação Ambiental. 27-28/09/2000. ESALQ/USP - Piracicaba/SP - Resumo não publicado. 
das flores está relacionado, num momento posterior, à queda das mesmas, cumprindo o ciclo natural da vida em que tais seres, a exemplo dos humanos, estão inseridos".

Malinsky (1985, p.37) lembra que atualmente, o espaço urbano é disputado por diversos sistemas como: habitação, produção, serviços, circulação, infra-estrutura, etc., e a "desarticulação dos diversos setores administrativos municipais responsáveis pela implementação de uma 'política' para as áreas verdes - planejamento, projetos, produção, obras, manutenção e ação comunitária - agravam a desvantagem junto aos outros sistemas já mencionados".

Por isso, Hoene (1944) citado por Lima (1993, p.18) já lamentava:

“... se levantam ramos, são perseguidas pelos que zelam pelos fios telefônicos e de energia elétrica, se abrem seus ramos e tocam as paredes ou cobrem demais as ruas, são atacadas pelos proprietários e condutores de veículos; se não adquirem um porte que corresponda às expectativas, são censuradas pelos transeuntes $e$ jardineiros da prefeitura; se lutam contra os obstáculos e procuram sustento e arrimo, demonstrando isto com as raízes pelo movimento que aduzem às calçadas, arrebentando o cimentado ou os ladrilhos, são agredidas pelos pedreiros que, para arrumarem o piso, cortam suas raízes, deixando-as sem segurança contra os vendavais e sem condição para viverem..."

Se há cinquenta anos atrás este tipo de relato já dava conta da penosa condição da árvore frente à agressividade do meio urbano, é fácil imaginar as proporções do problema em nossa época.

Para Lima (1993)

"o afluxo populacional, acentuado, generalizado e desorganizado, às cidades, impondo necessidades quanto às novas áreas urbanizadas ou, também, na multiplicação da capacidade daquelas já existentes, entre outras implicações econômicas e sociais, tem comprometido, quase sempre de maneira irracional, a parte mais vulnerável do contexto vegetal urbano: sua arborização viária. Na duplicação ou abertura de novas avenidas e ruas, na convivência forçada e, quase nunca, salutar com solos mais compactados e impermeabilizados, número crescente de veículos, fiação aérea e, algumas vezes, até com cidadãos menos esclarecidos, as árvores do verde viário acabam por encontrar algumas de suas mais graves limitações" (Lima, 1993, p.01). 
Segundo a autora, o ambiente urbano prejudica o desenvolvimento das plantas através de poluição urbana, estresses climáticos, problemas nutricionais, pragas e doenças, compactação do solo, danos físicos e podas.

Soares (1998, p.19) reafirma todos estes pontos, mas é otimista ao dizer que "tudo se compatibiliza, em face dos recursos modernos da ciência e da arte e à imensa riqueza de tipos e formas vegetais que a flora de qualquer região nos oferece”.

Porém, a arborização viária também causa transtornos aos moradores das cidades. Embora na maioria dos casos esses problemas sejam resultantes de erros e falhas no planejamento e implantação dessa arborização.

Lima (1993)enumera alguns desses principais problemas:

- "Escurecimento diurno e noturno de ruas, jardins e fachadas das casas;

- entupimento de calhas e quebra de telhas;

- ruas, calçadas e propriedades com o piso destruído;

- canalizações deslocadas, obstruídas ou quebradas;

- avarias e quedas de fios da rede elétrica e de telefonia;

- emboloramento e danos nas fachadas das edificações;

- prejuízo à posteação, placas de sinalização, semáforos, trânsito de veículos e pedestres;

- encobrimento de letreiros ou propagandas comerciais" (Lima, 1993, p.33).

Além desses problemas, a consulta à moradores de Piracicaba, exposta num capítulo seguinte desta dissertação, mostra que eles se queixam também da sujeira provocada pela queda de folhas e flores, da aglomeração de pessoas e carros sob as sombras das árvores (incômoda para o morador do imóvel cuja árvore encontra-se em frente à sua casa), de acidentes e estragos provocados por queda de árvores, e alguns outros inconvenientes.

Diante desses inúmeros transtornos e problemas, grande parte dos moradores das cidades passam a enxergar a árvore como um objeto incômodo e descartável, esquecendo-se dos muitos benefícios que ela lhes proporciona. O resultado desse antagonismo se traduz em depredações, maus tratos, podas mutiladoras, anelamentos criminosos, aplicação de substâncias tóxicas e supressão das árvores viárias. 
Lima (1993) cita Biondi (1985) que verificou em Recife, que mais de $1 / 3$ das árvores plantadas ao longo de ruas e avenidas apresentavam danos físicos causados pela população e que, além disso, um grande número de solicitações à Prefeitura Municipal, para remoção dessas árvores, ocorrera durante a fase de coleta dos dados.

Um estudo realizado por Bueno et al. (1994, p.579), na cidade de Botucatu/SP, mostra que de 1987 a 1993, ou seja num espaço de apenas 6 anos, a população eliminou 30,7\% das árvores das vias públicas da região central daquela cidade.

Em seu trabalho entitulado "Áreas Verdes nas Grandes Cidades" Geiser et al. (1975, p.01) conclui que

"a situação do 'verde' nas cidades é agravada pela necessidade de preparar a população para recebê-lo. Assim, a vegetação é constantemente depredada, enquanto que solicitações para 'derrubar a árvore que está sujando a calçada da rua', por incrivel que pareça são comuns. - O povo ainda não está acostumado a conviver com o 'verde', ainda não conhece os benefícios que proporciona'.

Detzel (1994, p.60) realizou uma avaliação monetária das árvores na cidade de Maringá/Pr, concluindo que árvores de 01 ano de idade representam um custo para a prefeitura de US\$ 59,40; árvores com 10 anos, US\$305; com 25 anos, US\$1.260 e com 50 anos de idade, US\$ 6.851. Estes valores expressam o custo médio de implantação e manutenção de cada árvore de rua.

Milano (1996) reafirma este ponto salientando que, ao recolher impostos e taxas, a população urbana está pagando pelos custos de planejamento, implantação, manejo e administração da arborização, sejam estes diretos, indiretos ou decorrentes, como por exemplo, o custo de varrição de ruas devido à folhas e flores caídas e desta forma deve exigir uma arborização de qualidade. 


\subsubsection{A predominância de espécies exóticas na arborização urbana}

Segundo Pegoraro (1998, p.11) "a fixação dos colonizadores e imigrantes europeus trouxe também a introdução de espécies exóticas de animais e plantas ornamentais, sem interesse agrícola ou econômico, talvez porque estabelecessem algum resquício de ligação entre os estrangeiros que aqui se radicaram e seus locais de origem, ou talvez por algum outro fator simbólico."

Transformado em hábito, o costume de plantar espécies exóticas em detrimento das espécies nativas, propagou-se rapidamente, tornando-se comum em grande parte das cidades brasileiras.

Burle-Marx (1979) citado por Pegoraro(1998, p.11), condenou o artificialismo paisagístico dos jardins urbanos: "a vegetação existente é encarada como mato e substituída por um exército de postes e bancos. A nova vegetação, quase sempre importada, é escolhida sem qualquer critério, fato que desvirtua a paisagem urbana".

Também Lorenzi (1992, p.X) afirma: “A maioria das plantas arbóreas cultivadas em ruas, avenidas, praças e jardins de nossas cidades são de espécies trazidas de outros países (espécies exóticas). Apesar de nossa flora contar com centenas de espécies de grande beleza e qualidade paisagísticas, ainda não foram descobertas por nossos jardineiros e paisagistas”. O processo de homogeneização da arborização urbana, com número limitado de espécies e abundância de exóticas, segundo Souza $\left(1979^{\mathrm{a}}, \mathrm{p} .12\right)$, acaba realimentado quando o produtor comercial de mudas cultiva as mais procuradas, consagradas pelo uso, que geralmente são as mesmas vistas nas ruas, praças e jardins, diminuindo as oportunidades de diversificação e utilização das nativas".

Souza (1982), traça um histórico da arborização urbana tomando como base a cidade de Campinas/SP, e acaba por demonstrar um pouco da história da arborização urbana em outras cidades do interior de São Paulo, onde sempre se configurou uma espécie de modismo, motivo que levou à muitas semelhanças na utilização de espécies entre uma cidade e outra. $\mathrm{O}$ autor fala de uma fase que chegaria até os anos 30 , onde 
somente algumas cidades grandes davam "um pouco de atenção para a arborização ainda insipiente, inexistente nas cidades pequenas".

Nesta fase predominavam nas ruas espécies como o Alecrim, o Alfeneiro do Japão, as Astrapéias ${ }^{3}$.

Numa segunda fase, que vai dos anos 30 até a década de 60, Souza fala da introdução intensiva de "Bauínias, Cássias, Chapéu-de-Sol, Espatódea, Flamboyant, Guarantã, Ipês, Jacarandá Mimoso, Pau-ferro, Pau-marfim, Sibipiruna, Resedá e Tipuana". Na terceira fase que chega até os dias atuais, segundo o autor, houve a introdução de outras espécies, "muitas delas ainda timidamente, enquanto outras se estão transformando em verdadeiras invasoras, tal a predominância", entre as quais cita: "Albizzia falcata (acácia falcata), Bauhinia triandra, Bombax malabaricum (paineira vermelha da India), Brachychiton populneum, cassia carnaval, Hibiscus

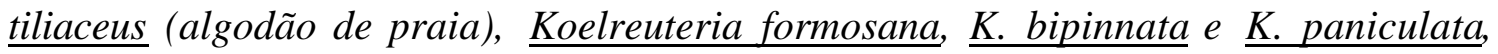
Largestroemia speciosa (resedá gigante), Schinus terebinthifolius (aroeira pimenteira)e Triplaris brasiliensis".

Visitas a viveiros municipais e passeios pela cidade de Piracicaba, permitem a constatação desta predominância, que se configura como um outro modismo, desta vez fomentado pelos técnicos e engenheiros de prefeituras, responsáveis pelo planejamento da arborização das cidades. Como ficará demonstrado no capítulo seguinte, em Piracicaba predominou durante muitos anos o plantio da Sibipiruna (Caesalpinia peltophoroides Benth.), árvore de imensa beleza e atrativos, mas que por uma série de motivos como a derrubada de suas minúsculas folhas e flores em determinadas estações do ano, acarretando alguns danos como o entupimento de calhas e "sujeira" nas calçadas, acabou por suscitar uma certa antipatia pelas árvores entre muitos moradores.

\footnotetext{
${ }^{3}$ Nesta dissertação utilizaremos sempre os nomes das espécies arbóreas conforme constam nos documentos e/ou bibliografias originais consultados, sem a preocupação com a identificação dos respectivos nomes científicos e/ou populares.
} 


\title{
2.2 O papel da Educação Ambiental
}

\author{
A Conferência de Tbilisi orienta que
}

\begin{abstract}
"Tanto nas áreas urbanas quanto nas rurais, a educação ambiental deve contribuir para a formação de cidadãos capazes de julgar a qualidade dos serviços públicos (saneamento, segurança, habitação, educação, locais de recreação, etc.). Em resumo, trata-se de dotar os cidadãos de espírito crítico e, ao mesmo tempo, fazê-los apoiar as medidas ambientais que realmente atendam às suas necessidades e ao desejo de melhorar a qualidade do meio ambiente e da sua própria existência" (UNESCO, 1997, p.69).
\end{abstract}

Medina (1997), lembra que:

“(...) no Brasil, a Política Nacional do Meio ambiente, definida por meio da Lei no. 6.983/81, situa a Educação Ambiental como um dos princípios que garantem 'a preservação, melhoria e recuperação da qualidade ambiental propícia à vida, visando assegurar no país condições ao desenvolvimento socioeconômico, aos interesses da segurança nacional e à proteção da dignidade da vida humana', e que deve ser oferecida em todos os níveis de ensino e em programas específicos direcionados para a comunidade, visando assim à preparação de todo cidadão para uma participação na defesa do meio ambiente" Medina (1997, p.260).

E de acordo com Guevara (1998):

"Estamos no meio de transições aceleradas: da era da informação para a do conhecimento e finalmente para a da consciência. Para facilitar elou amenizar esse processo de parto para o Homo universalis, certas medidas podem ser tomadas na área educacional de forma a criar a sinergia necessária para detonar processos de transformação coletiva de consciência. Elas estão diretamente relacionadas com a recuperação de valores éticos, estéticos e espirituais na sociedade como um todo e com a reaproximação com a Mãe Natureza, da qual sempre fomos parte e com quem sempre podemos aprender princípios dármicos básicos de convivência harmônica" (Guevara,1998, p.63).

Segundo ele precisamos atuar na sociedade visando recuperar "nossa sensibilidade natural para o bem, o belo e o verdadeiro” (Guevara,1998, p.63). 
Partindo-se destas leituras, pode-se assumir que o campo da educação ambiental é uma das "portas de entrada" para uma transformação coletiva. Outras "portas" como as religiões e a filosofia, por exemplo, certamente são ou serão utilizadas.

A partir da avaliação dos processos de amadurecimento de diversos projetos de educação ambiental, Sorrentino (2000) sugere que eles tendem a:

- instigar o indivíduo a analisar e participar na resolução dos problemas ambientais da coletividade;

- estimular uma visão global (abrangente/holística) e crítica das questões ambientais;

. promover um enfoque interdisciplinar que resgate e construa saberes;

- possibilitar um conhecimento interativo através do intercâmbio/debate de pontos de vista;

- propiciar um auto-conhecimento que contribua para o desenvolvimento de valores (espirituais e materiais), atitudes, comportamentos e habilidades. (Sorrentino, 2000a, p.111)

Em outro artigo publicado posteriormente, Sorrentino $\left(2000^{\mathrm{b}}\right.$, p.95-104) avalia que a crise ambiental suscita o debate de três temas centrais dentro do chamado ambientalismo: "sobrevivência", "participação" e "emancipação" ou "autonomia". Segundo ele, pode-se derivar daí, sugestões de métodos, objetivos e atividades educacionais que contribuam para a construção de sociedades sustentáveis. E o grande desafio que o autor coloca é a incorporação desses três princípios às temáticas trabalhadas, "independentemente da porta de entrada que nos aproxima da educação ambiental" (Sorrentino, 2000 , p.103).

Portanto, trabalhar qualquer tema através da educação ambiental, seja ele a questão das árvores ou do lixo, da saúde ou da educação no trânsito, da extinção de espécies à emissão de gases poluentes, entre uma infinidade de outros temas, implica em, não somente provocar mudanças de atitudes e comportamentos relacionados a cada questão especificamente, mas sim aproveitá-los como oportunidades potenciais para uma transformação mais profunda, que possa resultar em mudanças de valores e aquisição de uma nova ética individual e coletiva, o que deverá provocar uma nova postura entre os seres humanos perante a vida. 
Carvalho(1992, p.1084) nos diz ‘...) educar para a cidadania é construir a possibilidade da ação política, no sentido de contribuir para formar uma coletividade que é responsável pelo mundo que habita", e isso vem de encontro aos propósitos da educação ambiental.

Tassara et al. (2001, p.31) falam de uma concepção de educação ambiental para sociedades sustentáveis voltada para uma possibilidade única de reconstruir nossa história, nossa relação com uma natureza cada vez mais modificada por nós mesmos, para o desejo de uma globalização verdadeira, solidária e capaz de gerar valores que ofereçam novos sentidos à existência humana no planeta.

Mas como alcançar tais objetivos através da educação ambiental? Será que suas ferramentas e metodologias são suficientes para tanto?

Viana e Hoeffel (1998, p.67) apresentam uma reflexão em torno do problema ambiental, propondo dois eixos básicos, que segundo eles estão menos presentes na literatura de apoio ao tema educação ambiental: "um diz respeito ao caráter formativo da educação ambiental, que deve promover no ser humano uma postura interna de reverência pela vida; o outro é o debate em torno dos modelos de desenvolvimento econômico que estão no centro do questionamento da relação homem-natureza".

Ao primeiro eixo chamam "ecologia do amor" "por considerar que o propósito básico da educação ambiental é formar pessoas amorosas, integradas ao sistema planetário e responsáveis pela vida na terra". Segundo essa reflexão, ao atingir este propósito, "a mudança interna se traduzirá em transformações de hábitos e comportamentos que, sem dúvida, se refletirão na adoção de modelos econômicos e societários mais justos e harmoniosos" (Viana e Hoeffel, 1998, p.67).

Através de uma reflexão baseada em princípios espiritualistas orientais, Viana e Hoeffel (1998, p.73-74) propõem uma nova forma de abordagem entre os "valores humanos e educação ambiental". Essa nova forma está baseada no "amor como base estrutural das relações". Observando que "toda ênfase da educação têm sido dada à apreensão de conhecimentos e ao domínio de técnicas, dentro do quadro referencial do paradigma científico predominante nas sociedades ocidentais de caráter urbanoindustrial", eles reconhecem a dificuldade da aceitação dessa "perspectiva analítica que 
define o amor como meta a ser atingida no processo educativo" por parte de muitos educadores. Mas alertam: "todo o conhecimento adquirido sobre as leis do universo, tanto no macrocosmo como no microcosmo, produziu um nível de degradação e impacto ambiental que pode comprometer a vida no planeta" (Viana e Hoeffel, 1998, p.73-74).

E finalizam "Portanto, praticar uma educação que busque tornar o amor a estrutura do agir humano é, antes de mais nada, desenvolver em nós mesmos a capacidade de amar. É estabelecer com a vida uma relação de alegria e gratidão, exercitando a amorosidade a cada instante, a capacidade de vivenciar experiências humanas e a afabilidade com todos os seres" (Viana e Hoeffel, 1998, p.75).

Para Gutierrez e Prado (1999, p.42) "o desenvolvimento de relações significativas tem a ver com a capacidade de todo ser humano de mobilizar sua sensibilidade, imaginação criadora, sua intuição, suas energias afetivas, seu amor...".

Assim, a Educação Ambiental, ao buscar em seus propósitos "de fundo" uma transformação real em termos de "despertar de consciências", deve buscar conteúdos e metodologias que a auxiliem nessa busca.

Os processos participativos empregados pela Educação Ambiental têm se demonstrado um campo fértil para a emergência de metodologias originais, inovadoras e capazes de trabalhar com o conteúdo subjetivo e complexo das questões trabalhadas. 


\title{
3 METODOLOGIA
}

\begin{abstract}
"Os sonhos individuais e coletivos são feitos de alegrias e dores. Esses sonhos transbordam cada vez mais da vida privada e ocupam, em massa, a praça pública. Um pensamento que sabe acompanharlhes os meandros é, certamente, o mais capacitado a deixar entrever a emoção, o sofrimento, o cômico, que é o próprio de uma vida que não se reconhece no esquema, preestabelecido, de um racionalismo de encomenda. É na dor e no sangue que se nasce para a existência. Mas é no maravilhar-se que é possível, bem ou mal, ir vivendo. É integrando tudo isso que se saberá ser o menos infiel possível à efervescência existencial característica da socialidade contemporânea. Nietzsche aconselhava a 'fazer do conhecimento a mais potente das paixões'. Para além das querelas de sábios, mas mantendo uma exigência intelectual, justamente a da 'gaia ciência', talvez seja possível que uma tal paixão culmine com um pensamento que se tenha reconciliado com a vida"

Elogio da Razão Sensível - Michael Maffesoli
\end{abstract}

Tendo em vista as particularidades de objetivos e métodos utilizados neste trabalho, classifico os trabalhos realizados em campo como fases 1 e 2 e as descrevo como:

Fase 1: diagnóstico sobre a situação da arborização viária em Piracicaba, sistema de gerenciamento e administração, fatores envolvidos na qualidade desta arborização e entrevistas com engenheiros e técnicos do setor. Foi realizada entre os meses de janeiro de 1999 a junho de 2000, com algumas complementações de dados feitas posteriormente, apontando a situação vivenciada naquele período.

Fase 2: pesquisa participante realizada com 2 grupos de moradores de Piracicaba. Realizada de julho a novembro de 1999. 
Os referenciais metodológicos e os métodos utilizados nas duas fases são explicados a seguir.

\subsection{Refere nciais metodológicos}

\subsubsection{Pesquisa qualitativa}

Tendo em vista que meus objetivos nesta pesquisa vão além do diagnóstico puro e simples da arborização viária em Piracicaba, buscando também a compreensão das diferentes maneiras de pensar dos agentes envolvidos em seu processo, encontrei em Mynaio (1996, p.21-22) argumentos importantes a subsidiar a escolha da pesquisa

qualitativa como referencial metodológico, pois segundo esta autora, ela tem a capacidade de trazer à tona "(...) o universo de significados, motivos, aspiração, crenças, valores e atitudes" envolvidos em determinada realidade.

De acordo com Van Maanen (1983) citado por Hoppen et. al. (1996) "as metodologias qualitativas são constituídas por um conjunto de técnicas interpretativas que têm por meta retraçar, decodificar ou traduzir fenômenos sociais naturais, com vistas à obtenção de elementos relevantes para descrever ou explicar estes fenômenos". Segundo Hoppen et. al. (1996), a tarefa do pesquisador, é obter, a partir de todos os dados colhidos, um conjunto de informações que permita dar um sentido àquilo que está sendo estudado, convencendo o leitor da pertinência e da veracidade de sua análise.

$\mathrm{Na}$ pesquisa qualitativa, o pesquisador tem um papel fundamental na interpretação da realidade estudada, passando a ser parte integrante dela, na medida em que o significado que lhe for atribuído depende também, além de suas evidências, da abordagem que o pesquisador irá lhe conferir.

Para Chizzotti (1991, p.79)

"O conhecimento não se reduz a um rol de dados isolados, conectados por uma teoria explicativa; o sujeito-observador é parte integrante do processo de 
conhecimento e interpreta os fenômenos, atribuindo-lhes um significado. $O$ objeto não é um dado inerte e neutro; está possuído de significados e relações que sujeitos concretos criam em suas ações" (Chizzotti,1991, p.79)

A pesquisa qualitativa auxilia as comunidades a entenderem sua realidade, propicia o afloramento de conflitos e ajuda na busca de soluções para seus problemas (Patton, 1980, p.11).

Além disso é uma metodologia de caráter interdisciplinar, buscando em várias áreas do conhecimento alcançar o entendimento da realidade abordando-a em sua complexidade (Denzin, 1970).

Para Stake (1983) todos os pesquisadores quantitativos utilizam abordagens qualitativas em suas pesquisas, e todos os pesquisadores qualitativos utilizam-se de quantidades em seus relatos. Este autor diferencia uma pesquisa da outra afirmando que a pesquisa quantitativa extrai dados de um grande número de casos sobre um pequeno número de variáveis enquanto a pesquisa qualitativa obtém dados de um pequeno número de casos sobre um grande número de variáveis. Para ele, o produto gerado na pesquisa quantitativa leva a explicações, enfatizando propriedades, populações, enquanto o produto que a pesquisa qualitativa deve gerar leva à compreensão com ênfase em generalizações.

Este tipo de pesquisa é utilizado principalmente no campo das ciências humanas e sociais. A subjetividade e a complexidade inerente a estes campos do conhecimento exigem análises que vão além do estudo fracionado ou isolado de determinados fenômenos sem a compreensão do todo.

Silva (1996) enumera os seguintes passos a serem seguidos pelo pesquisador qualitativo para que os leitores elaborem suas generalizações:

a) apresentar relatos ou descrições suficientes dos fenômenos estudados, discursos e entrevistas realizadas;

b) apresentar interpretações próprias e de outros pesquisadores sobre o assunto;

c) apresentar os processos pelos quais os dados foram coletados, analisados, sintetizados e interpretados, bem como os procedimentos de validação empregados. 
A pesquisa qualitativa usa preponderantemente dados extraídos do discurso linguagem - ou da observação direta do comportamento dos sujeitos envolvidos na questão e da realidade estudada, fazendo pouco uso de procedimentos estatísticos.

As técnicas e instrumentos de pesquisa devem ser adequadas aos objetivos e ao contexto da realidade estudada, exigindo do pesquisador grande senso crítico, criatividade e dinamismo para combiná-las e aplicá-las de acordo com as necessidades. Várias técnicas são descritas na literatura da área como possíveis de serem utilizadas em pesquisa qualitativa: observação participante, histórias de vida, depoimentos pessoais, entrevistas não-estruturadas, semi-estruturadas ou abertas(individuais ou coletivas), análises de discursos, análises documentais, isolados ou nas mais diversas combinações (Silva, 1996). Silva cita Alves (1991, p.60): "(...) o que não quer dizer que outros métodos, inclusive quantitativos, não possam ser usados".

\subsubsection{Estudo de caso}

O Estudo de Caso é uma das metodologias empregadas em pesquisas qualitativas.

De acordo com Becker (1993, p.13) o que torna determinado ambiente e determinado problema o que são de modo único, são justamente as suas variações locais e peculiaridades, que devem ser levados em conta pelas ciências sociais em suas investigações.

Partindo deste princípio tomei como referencial metodológico o Estudo de Caso em minha investigação sobre a situação da arborização viária em Piracicaba, pois ele permite alcançar uma compreensão da realidade local levando em consideração fatores de diversas naturezas, que fatalmente existem, inter-relacionam-se e definem o quadro atual desta arborização. 
De acordo com Yin (2001), "a necessidade de se utilizar a estratégia de 'Estudo de Caso' deve nascer do desejo de entender um fenômeno social complexo”, sendo esta metodologia preferida quando o "tipo de pesquisa é da forma 'como' $e$ 'por que?'; quando o controle que o investigador tem sobre os eventos é muito reduzido ou quando o foco temporal está em fenômenos contemporâneos dentro do contexto da vida real". Sua tendência central está geralmente focada na tentativa de esclarecer "uma decisão au um conjunto de decisões: porque elas foram tomadas? Como elas foram implementadas? Quais os resultados alcançados?".

Ainda segundo este autor, o Estudo de Caso é uma pesquisa empírica que:

“. investiga um fenômeno contemporâneo dentro do seu contexto real, . as fronteiras entre o fenômeno e o contexto não são claramente evidentes, . múltiplas fontes de evidência são utilizadas” (Yin, 2000) .

Hoppen et al. (1996) complementam todos estes pontos dizendo que este método de estudo permite examinar um dado fenômeno em seu meio natural, utilizando-se múltiplas fontes de evidência (indivíduos, grupos, organizações), e pelo emprego de métodos ou técnicas diversificadas de coleta de dados. Não há manipulação ou controle dos sujeitos pelo pesquisador e, além disso, é um método que permite estudar fenômenos que estão em curso e também os que já aconteceram.

\subsubsection{Pesquisa participante}

Utilizou-se pesquisa participante para conhecer a opinião de alguns moradores sobre arborização urbana, compreender a sua percepção sobre as árvores, investigar quais incômodos as árvore viárias lhes proporcionam e por outro lado quais os vínculos existentes nesta relação entre seres humanos urbanos e suas árvores de rua. 
Essa escolha baseourse na constatação de que, para buscar respostas aos questionamentos apontados anteriormente, seria necessária a apreensão de conteúdos um pouco ou bastante subjetivos, os quais não seriam possíveis de alcançar com a utilização apenas de técnicas mais tradicionais de pesquisa.

Encontrei no conceito de Pesquisa Participante um recurso que não só poderia oferecer-me ferramentas para a investigação proposta, como também transformaria esta pesquisa em um momento de reflexão e envolvimento com o tema para os moradores que tomariam parte dela.

De acordo com Haguette (1992, p.109) alguns pontos característicos desta proposta são:

"(...) a crítica à metodologia da pesquisa tradicional das ciências sociais, especialmente no que se refere à sua falta de neutralidade e objetividade; a recusa de aceitação do postulado de distanciamento entre sujeito e objeto de pesquisa, o que remete à necessidade não só da inserção do pesquisador no meio, como de uma participação efetiva da população pesquisada no processo de geração de conhecimento, concebido fundamentalmente como um processo de educação coletiva; finalmente, o princípio ético de que a ciência não pode ser apropriada por grupos dominantes conforme tem ocorrido historicamente, mas deve ser socializada, não só em termos do seu próprio processo de produção como de seus usos (...)" (Haguette, 1992, p.109).

Todos estes pontos reforçam minha escolha acerca da metodologia utilizada.

$\mathrm{Na}$ pesquisa participante o pesquisador e o sujeito da pesquisa trabalham juntos na busca de explicações para os problemas e fenômenos estudados e ela por si mesma já é um processo educativo, que permite que as pessoas envolvidas no problema conheçam sua realidade e busquem caminhos para transformá-la.

Thiollent (1985) confirma esta idéia ao afirmar que pesquisa participante é uma proposta metodológica que "consiste em dar aos pesquisadores e grupos de participantes os meios de se tornarem capazes de responder com maior eficiência aos problemas da situação em que vivem, em particular sob a forma de diretrizes de ação transformadora"(Thiollent, 1985, p.108)

A Pesquisa Participante é um recurso metodológico já bastante pesquisado e utilizado pela Educação Ambiental, conforme nos relata Viezzer e Ovalles (1994, p.52- 
53), no Manual Latino-Americano de Educação Ambiental. Segundo os autores, recurso consiste em

"gerar na comunidade afetada um processo de autodiagnóstico ou autoconhecimento, a fim de que os seus membros não só fiquem conscientes do problema, mas que conheçam as causas responsáveis e procurem soluções (...).

(...) Baseia-se no fato de saber-se que em relação a cada caso concreto de deterioração ambiental, criam-se versões que mascaram as causas, as soluções e, logicamente, os responsáveis. Estas versões proporcionam explicações e aparentes soluções que acabam sempre perpetuando o problema. Mas o problema ainda é maior: as estruturas ideológicas vão criando um tipo especial de inconsciência que faz aceitar passivamente as situações criadas" (Viezzer e Ovalles, 1994, p.52-53).

Assim, para Viezzer e Ovalles (1994)

"o método de autodiagnóstico gestado no interior de uma comunidade, além de ter como objetivo incrementar o conhecimento das características, causas e atores sociais envolvidos no seu problema ambiental, deve estimular uma prática geradora de mudança na percepção e na atitude das pessoas perante o seu problema. Pretende-se que a comunidade se aproprie realmente da situação e possa gerar meios para começar a transformá-la. E que nesta busca de mudanças para uma melhor qualidade de vida consiga fazer as necessárias conexões das questões locais com a situação global planetária" (Viezzer e Ovalles, 1994, p.53).

Mais adiante estes autores sintetizam os procedimentos para a realização de uma pesquisa participante:

". Determinar que partes da pesquisa devem necessariamente ser realizadas por profissionais pesquisadores e pelos educadores e educadoras populares. Elaborar a forma de captar e transmitir este conhecimento.

- Determinar que parte da pesquisa é de responsabilidade direta da comunidade. Elaborar o procedimento pelo qual serão proporcionadas técnicas e métodos previamente escolhidos a fim de conhecer, sistematizar e ampliar as suas experiências.

- Buscar formas de motivar o processo de autopesquisa e conduzir, sem induzir, as atividades.

- Fazer a síntese das conclusões conjuntamente com a comunidade.

- Preparar uma versão em linguagem técnica para a instituição onde trabalham pesquisadores ou educadores. Da mesma maneira, preparar uma versão de divulgação para o uso prático das comunidades." (Viezzer e Ovalles, 1994, p.59). 
Oliveira e Oliveira (1982, p.19) reforça esta escolha metodológica ao afirmar que " a finalidade de qualquer ação educativa deva ser a produção de novos conhecimentos que aumentem a consciência e a capacidade de iniciativa transformadora dos grupos com quem trabalhamos. Por isso mesmo, o estudo da realidade vivida pelo grupo e de sua percepção desta mesma realidade constituem o ponto de partida e a matéria-prima do processo educativo"

\subsubsection{Percepção ambiental}

Yi-FuTuan (1974, p.01) fala que a abordagem de temas como "percepção"

"preparam-nos, primeiramente, a compreender a nós mesmos. Sem a autocompreensão não podemos esperar por soluções duradouras para os problemas ambientais que, fundamentalmente, são problemas humanos. E os problemas humanos, quer sejam econômicos, políticos ou sociais, dependem do centro psicológico da motivação, dos valores e atitudes que dirigem as energias para os objetivos" (YiFu Tuan, 1974, p.01).

e define: percepção é tanto a resposta dos sentidos aos estímulos externos, como a atividade proposital, na qual certos fenômenos são claramente registrados, enquanto outros retrocedem para a sombra ou são bloqueados" (Yi-Fu Tuan, 1974 p.04).

Ferrara (1993) afirma que os usos e hábitos constituem a manifestação concreta do lugar urbano, construindo sua imagem. Porém esta imagem torna-se opaca devido à rotina cotidiana, o que impede sua percepção. O lugar torna-se, então, homogêneo, ilegível, sem codificação. Neste sentido a percepção ambiental surge então, como um mecanismo que permite superar essa opacidade, gerando conhecimento a partir da informação retida, codificada naqueles usos e hábitos.

De acordo com esta autora

"a percepção como controle da experiência urbana surge como aquela dimensão da linguagem responsável pelo desenvolvimento da capacidade de apreender o cotidiano da cidade e extrair, daí, os elementos capazes de estimular a 
ação, o comportamento e a intervenção sobre ela. Aprendizado e mudança de comportamento são os fatores que caracterizam apreensão e produção de informação, percepção enfim" (Ferrara, 1993, p.107)

Baseando-me nas colocações desses autores, tento trazer à tona "traços" desta percepção que permeia a relação entre esses moradores e as árvores viárias. Como eles percebem e avaliam a arborização de seu bairro? Obter informações que levem à conclusões sobre esta "relação" e ainda, estimular um "olhar mais atento" sobre sua realidade, aguçar os sentidos, e provocar reflexões, são os objetivos a alcançar através deste exercício.

\subsection{Técnicas utilizadas na Fase 1:}

\section{- Entrevistas}

Utilizei a técnica de entrevistas semi-estruturadas, que segundo Lüdke e André (1986, p.34) se desenrolam "a partir de um esquema básico, porém não aplicado rigidamente, permitindo que o entrevistador faça as necessárias adaptações". Os roteiros para as entrevistas encontram-se no anexo apêndice 03. Além desta técnica de entrevista, em alguns casos utilizei entrevistas abertas, que não seguem nenhum roteiro básico, com a finalidade de extrair opiniões, fatos ou "insights" que pudessem emergir durante as conversas. Algumas vezes utilizei ambas as técnicas durante uma mesma entrevista.

Assim, procurei captar através dessas entrevistas, além das informações qualitativas e quantitativas que ajudariam a compor o quadro da arborização viária na cidade, as experiências e opiniões pessoais dos profissionais responsáveis pela arborização urbana em Piracicaba, deixando-os durante a entrevista, falar livremente sobre determinados temas previamente estabelecidos. Muitas vezes durante estas conversas surgiam outros temas ligados ao assunto, até então desconhecidos ou 
ignorados por mim, e procurei explorá-los convenientemente deixando o entrevistado discorrer à vontade sobre esses temas.

Estas entrevistas foram em sua maior parte registradas através de anotações durante a sua realização. Algumas delas puderam ser gravadas e posteriormente transcritas para análise.

Foram entrevistados cinco engenheiros agrônomos, um engenheiro florestal e dois técnicos que trabalham para a SEDEMA (Secretaria de Defesa do Meio Ambiente do Município de Piracicaba), um funcionário da guarda civil (Pelotão Ambiental), dois políticos ligados à militância ambientalista na cidade, um especialista em arborização urbana que foi consultor da Prefeitura Municipal de Piracicaba em anos anteriores e um professor da ESALQ.

\section{- Pesquisa documental}

Procurei através de fontes escritas complementar e entender as informações coletadas nas entrevistas e formar um quadro geral e explicativo da situação da arborização viária na cidade de Piracicaba..

De acordo com Diniz (1999, p.64) "a análise documental permite desenvolver novos aspectos de um tema ou problema e complementar informações obtidas por outras técnicas"

Deste modo procedi à análise de documentos como relatórios técnicos, listagens, artigos científicos, teses, guias de arborização, artigos de jornais, mapa da cidade, legislação municipal e fotografias, que auxiliaram a fundamentar a pesquisa.

\section{- Observação direta}

Quivy e Campenhoudt (1988) nos dizem que a "observação engloba o conjunto das operações através das quais o modelo de análise (constituído por hipóteses e por 
conceitos) é submetido ao teste dos factos e confrontando com dados observáveis". Os autores apresentam a técnica da observação direta como sendo baseada na observação visual em seu sentido restrito, sendo capaz de captar comportamentos sem a medição de um documento ou de um testemunho.

De acordo com Coelho (2000) esta técnica é um recurso amplamente utilizado nas pesquisas do tipo qualitativo para identificação do contexto e dos processos que envolvem o estudo em questão. $\mathrm{O}$ pesquisador a utiliza individualmente, sem o envolvimento dos sujeitos pesquisados, observando diretamente a situação e o cenário que envolve o estudo, visando contextualizar, mapear e relacionar os aspectos envolvidos no processo. Aqui o pesquisador é observador, registrando o que está investigando.

Desta forma, utilizei a observação direta para verificar o cenário e os aspectos da arborização viária na cidade, relacionando-as às informações obtidas através das entrevistas e da análise documental, e também para guiar-me na busca de respostas à questões que surgiam como consequiência desta observação.

No decorrer da pesquisa estas observações foram sendo anotadas em um caderno de campo, sendo utilizadas em diversos momentos para subsidiar reflexões, conclusões e identificação de caminhos exploratórios para o estudo.

\subsection{Técnicas utilizadas na Fase 2:}

\section{- Oficina de Futuro}

As reuniões com os grupos pesquisados foram realizadas adaptando-se as dinâmicas de "Oficina de futuro". Através dessa proposta, os integrantes do grupo apontam problemas e questões dentro de um tema, idealizando a situação desejada. Posteriormente, o grupo trabalha/discute soluções para os problemas apontados. (Instituto Ecoar para a Cidadania, 1997, p.5). 
"Oficinas de futuro" foram desenvolvidas pelo Programa Educ-Ação Ambiental que se realizou nas zonas norte e leste da cidade de São Paulo, junto às comunidades que vivem nas sub-bacias hidrográficas cujos principais córregos estão sendo afetados pelas obras do PROCAV II - Programa de Canalização de Córregos, Implantação de Vias e Recuperação Ambiental e Social de fundos de Vale. O relato dessas “oficinas", conforme transcrito no apêndice 02 , orientou a realização dos trabalhos de campo junto aos grupos.

\section{- "História do pedaço"}

Com a finalidade de investigar e compreender particularidades do histórico da arborização viária dos bairros nos quais os participantes dos grupos residiam, foi proposta a investigação da história da arborização do bairro, técnica também extraída do Programa Educ-Ação Ambiental citado acima, sob o nome de "história do pedaço",.

No grupo de jovens esta história foi construída a partir de entrevistas realizadas por integrantes dos grupos que voluntariamente se dispuseram a realizá-las. Um gravador com fitas K-7 era-lhes fornecido com a instrução de que entrevistassem pessoas mais idosas, ou que residissem a mais tempo no bairro, procurando investigar como era bairro antigamente, se existiam mais árvores ou não, se houve mudanças na paisagem e como estas pessoas percebiam isso.

Após a coleta destas entrevistas a pesquisadora as transcrevia e, numa reunião posterior e juntamente com o grupo, analisava os relatos, agrupando-os em ordem cronológica e de temas. Num flip-chart a história era "contada" a partir destas informações. A partir daí refletia-se e debatia-se sobre ela.

Já no grupo de terceira idade, não houve voluntários para a realização das entrevistas gravadas, e como seus integrantes já residiam em seus bairros há bastante tempo, guardando na memória os principais fatos e mudanças em sua paisagem, construiu-se a "história do pedaço" a partir de suas próprias lembranças, que foram emergindo durante uma das reuniões realizadas com este grupo. Esta história não foi 
escrita num flip-chart, mas as reflexões que surgiram no grupo foram gravadas e transcritas pela pesquisadora.

Através desta técnica foi possível observar que a percepção em relação ao seu meio ambiente ficou bastante aguçada nos dois grupos pesquisados. Inúmeras reflexões foram produzidas, e o reconhecimento do "como" e "porque" de sua paisagem ser do modo como é hoje levoutos a uma compreensão mais profunda sobre a inter-relação "ser humano-meio ambiente".

\section{- Fotografias e expressão artística}

Como recursos técnicos para a captação da percepção ambiental utilizoutse a fotografia e a expressão artística.

Adams (1936, p.132) incentiva a utilização da arte nos trabalhos ligados à área ambiental afirmando que "a arte aqui é importante ao desenvolvimento do sentido de posse e identidade em relação ao meio ambiente. Ela é usada como um meio de intensificar experiências, influenciar a percepção, permitindo aos estudantes que reflitam sobre a experiência adquirida e possam reprocessá-la para que faça sentido". De acordo com esta autora, a arte encoraja ainda, uma abordagem que enfatiza a crítica, ajudando a formar julgamentos de avaliação sobre qualidade.

Segundo Ferrara (1993, p.115-116) a fotografia permite flagrar índices de percepção ambiental, sendo bastante útil para complementação das diversas linguagens utilizadas na pesquisa. "permite atingir uma dimensão cultural impossível de ser conquistada com recursos mais lógicos, como questionários ou entrevistas, exclusivamente" (Ferrara, 1993, p.116).

Assim, com a recomendação de que retratassem a relação entre seres humanos e as árvores (positivas e/ou negativas), distribuí entre os participantes interessados em participar desta atividade, uma máquina fotográfica com filme, para ser revezada entre eles, instruindo-os a fotografarem cenários que retratassem a relação entre os seres humanos e as árvores. 
Posteriormente, sessões de exibição dessas fotos foram montadas, e para análise desta percepção foram levados em conta não só os registros contidos nas fotos, mas também as reações e as falas das pessoas que assistiam a essas exibições, pois estas modalidades de informação complementam-se entre si.

Através da expressão artística foi possível trazer subsídios complementares ao recurso da fotografia. Para este exercício, deixei-os livres para manifestarem seu sentimento sobre a relação entre seres humanos e árvores da maneira como desejassem. Para subsidiar esta escolha conversávamos um pouco sobre as várias opções de linguagem existentes: música, desenho, pintura, escultura, literatura, poesia, etc.

No grupo de jovens alguns integrantes optaram durante a reunião, por algumas dessas linguagens, comprometendo-se a trazer na próxima reunião o resultado de sua produção, que consistiu em uma canção (letra e melodia apresentada pela banda da qual estes integrantes faziam parte), e de um desenho de quadrinhos. Já no grupo de terceira idade nenhum integrante do grupo assumiu esta tarefa, sendo que mesmo assim, na reunião seguinte, uma pessoa trouxe uma poesia de sua autoria, apresentando-a ao grupo.

\section{- Questionários}

Desenvolvi um questionário (Apêndice 04) contendo algumas perguntas objetivas visando obter informações sobre a opinião dos moradores a respeito das árvores viárias, além de outras de caráter mais subjetivo, que visavam captar alguns sentimentos vivenciados através do contato das pessoas com as árvores.

Este questionário foi aplicado aos grupos, durante as reuniões, e foi utilizado por seus membros em entrevistas com moradores de seu bairro. Para isso, várias cópias do questionário foram distribuídas entre os participantes que desejassem colaborar com esta atividade, com a instrução para que entrevistassem vizinhos, parentes e/ou amigos durante a semana, retornando os questionários preenchidos na reunião seguinte. 


\section{- Palestra com apresentação de material ilustrativo/slides}

Para este recurso foi realizada uma pequena palestra, com repasse de informações e apresentação de slides com fotos sobre situações reais encontradas no próprio bairro e na cidade e exemplos de cenários com presença abundante de árvores.

Marques (1986, p.9) nos estimula a utilizar esta técnica lembrando que "de qualquer projeto de transformação social não pode estar ausente a visão da sociedade que se tem e da que se quer".

Este tipo de atividade destaca-se por possibilitar melhor entrosamento entre o pesquisador e o público pesquisado, e além disso é o momento em que o pesquisador passa a ter uma participação mais ativa e menos diretiva, na medida em que ele pode agora contribuir com a sua experiência sobre o tema, apresentando as informações que reuniu e compartilhando-as com o grupo. Verifica-se que uma vez estimulados pelas informações que lhe são transmitidas, os membros do grupo passam a desejar expressar suas críticas, sugestões e comentários sobre o tema.

\subsubsection{A escolha dos grupos pesquisados/aproximação/número de reuniões realizadas:}

Inicialmente, foram escolhidos três grupos para a realização da pesquisa. O desejo inicial era de trabalhar com faixas etárias distintas, compreendendo jovens, adultos e pessoas de terceira idade, a fim de captar diferentes percepções sobre o tema, resultantes da diferença de geração.

Assim, escolheurse um grupo de jovens, organizados na Igreja São Judas, situada entre o Bairro São Dimas e o Bairro Vila Independência, um grupo de terceira idade que 
faz parte do Programa Universidade Aberta à Terceira Idade da ESALQ/USP, e um Centro Comunitário situado no Jardim Brasília.

- Grupo de Jovens da Igreja São Judas: A escolha do grupo de jovens da Igreja São Judas foi motivada pelo fato de serem seus integrantes, moradores de bairros adjacentes à Igreja São Judas. Por serem bairros antigos, localizados em regiões intermediárias entre o centro e a periferia da cidade e apresentarem uma arborização viária que vai se empobrecendo aos poucos, com a predominância de exemplares de Sibipiruna, a escolha deste grupo poderia trazer muitos subsídios para a pesquisa.

Deste grupo fazem parte cerca de 20 a 30 jovens, com idades entre 13 e 27 anos, que se reúnem aos domingos pela manhã na sede da Igreja São Judas. Numa primeira aproximação, contatei o coordenador do grupo que se mostrou prontamente disposto a colaborar e assim, marcamos a primeira reunião. Realizamos quatro reuniões, com média de participação entre 20 e 30 pessoas.

- Grupo da "Universidade Aberta à Terceira Idade": O grupo de terceira idade da ESALQ foi escolhido pela facilidade de acesso a seus organizadores e integrantes, já que a sua coordenação é centrada dentro da própria ESALQ.

Este grupo reúne cerca de 350 pessoas, que não têm uma ocasião comum de encontro, dividindo-se em atividades inúmeras que vão de ginástica a viagens turísticas. Assim, tive que agendar uma reunião prévia sobre o assunto "meio ambiente", deixando em sua sede cerca de 300 convites (Apêndice 05). Conforme pude perceber mais tarde, eles ocupam-se com uma série de atividades, acostumados com agendas cheias e muitos focos de interesses. Talvez essa possa ser apontada como uma das razões para o baixo número de pessoas que compareceram às duas reuniões realizadas: apenas sete pessoas.

- Centro Comunitário do Jardim Brasília - Diversas fontes apontaram- me este Centro Comunitário como um grupo organizado e forte, motivo que levou-me a escolhê-lo para minhas pesquisas. Tentei diversas abordagens através de sua diretoria, porém infelizmente viviam um momento de desarticulação e desinteresse dos moradores em 
participar das reuniões. A pesquisa não foi realizada com este grupo devido à impossibilidade de reuni-lo. Como o tempo para a realização da pesquisa já estava bastante comprometido, não foi possível buscar outro grupo.

\subsubsection{Roteiro das reuniões}

Para a primeira reunião com cada grupo foi aplicado o seguinte roteiro:

Dinâmica 1: "Árvore da Esperança" - montou-se uma grande árvore, desenhada e recortada em cartolina colorida, afixada em um painel com alfinetes. No meio dela foram afixadas algumas perguntas, que os participantes dos grupos respondiam em fichas na forma de folhas, que lhes eram distribuídos para que escrevessem, desenhassem ou pintassem o que pensavam a respeito do tema proposto. Ao final de um período de tempo, todos penduravam suas "folhas" com as respostas na "árvore da esperança", que ficava exposta durante alguns minutos para observação conjunta do grupo. A cada rodada sentávamos e discutíamos sobre as respostas.

Pergunta 1: “Como você gostaria que fosse a rua/bairro em que mora?”

Pergunta 2: "Como você gostaria que fosse a arborização de sua rua/bairro?”

Dinâmica 2: “Muro das Lamentações" - como na dinâmica anterior, montoutse um grande muro, desenhado e recortado em cartolina e afixado em painel, seguindo o mesmo processo anterior. 


\section{Pergunta 3: Quais são os problemas que as árvores trazem aos moradores em sua rua?}

Dinâmica 3: “distribuição de tarefas” - após as conversas, eu pedia a colaboração espontânea de alguns membros do grupo na realização de tarefas que nos permitiram resgatar um pouco da história da arborização de seu bairro ou cidade e montarmos algumas atividades que os fariam refletir sobre a árvore em seu cotidiano. Dava-lhes as seguintes opções:

.Fotografia: A orientação era dada para que procurassem retratar a relação entre os seres humanos e as árvores, percebidas em seu cotidiano. Para essa tarefa eles recebiam uma máquina fotográfica com filmes, que era revezada entre os voluntários à tarefa.

.Entrevistas com gravador: para os que se ofereciam a essa tarefa, eu entregava um gravador e uma fita k-7, com a orientação para que gravassem depoimentos de pessoas mais velhas ou que residissem em sua rua ou bairro há bastante tempo, sobre como era a arborização do bairro antigamente.

Aplicação de questionários: $\mathrm{O}$ questionário mostrado no apêndice 03 foi distribuído a todos os membros do grupo para que o respondessem e levassem cópias, em quantidades variáveis de acordo com a disposição de cada um em aplicá-lo entre seus vizinhos e colegas, e ajudou a compor um quadro sobre suas opiniões e nível de informação sobre o tema.

.Expressão artística: aqui era-lhes sugerido que procurassem expressar através de desenhos, poesias, músicas, etc, o seu sentimento sobre a relação entre os seres humanos e as árvores, aquilo que era percebido em seu cotidiano. 
Já a segunda reunião era conduzida da seguinte forma:

Primeira Parte: Apresentação do material resultante da "expressão artística" . Após isso, o material fotográfico era exposto num mural e discutido e dele pode-se discorrer sobre a percepção ambiental que norteava essa relação com a natureza.

Depois falávamos sobre o material obtido com as entrevistas gravadas e resgatávamos um pouco da história da arborização em seu bairro e cidade. Montamos então um resumo dessa história (a história do pedaço) em um flip chart e refletíamos sobre "como era antes".

Segunda Parte: Apresentação de slides: após a apresentação dos trabalhos realizados por eles, seguia-se uma apresentação de slides tirados por mim, retratando cenários e situações existentes em seu próprio bairro, em outras regiões da cidade e também trazidas de cidades vizinhas. Nesse material procurei coletar imagens negativas e positivas. Discutíamos e avaliávamos os cenários.

\subsection{Análise dos resultados}

Baseando-me nas explicações de Lüdke e André (1986) lancei mão da avaliação qualitativa em minha pesquisa, levando em conta a necessidade de explorar informações de naturezas diversas e muitas vezes subjetivas, que exigem "que o pesquisador vá além, ultrapasse a mera descrição, buscando realmente acrescentar algo à discussão já existente sobre o assunto focalizado." (Lüdke e André, 1986 p.49).

Para esses autores, diferentemente dos estudos tradicionais, as avaliações qualitativas permitem chegar à representação da realidade de uma forma aceitável para 
outros observadores, concordando que possam existir outras representações e interpretações igualmente aceitáveis (Lüdke e André, 1986, p.52).

Segundo Silverman (1995) citado por Hoppen et al. (1996) a análise de dados em pesquisa qualitativa normalmente compreende 3 etapas: a codificação dos dados, a sua apresentação de forma mais estruturada e a análise propriamente dita.

Deste modo os dados coletados através das diferentes técnicas foram classificados e analisados com vistas à obtenção de um julgamento qualitativo sobre a realidade pesquisada.

Procedi à análise dos materiais obtidos a partir das técnicas empregadas nas diferentes fases do estudo utilizando a técnica de análise de conteúdo, seguindo as seguintes etapas descritas por Coelho (2000):

- pré-análise - leitura flutuante e organização do material;

- descrição analítica - desenvolvimento do sistema de codificação, codificação, classificação, categorização e elaboração do quadro de referência;

- interpretação referencial estabelecimento de relações.

$\mathrm{Na}$ fase 1 os dados documentais, os dados observacionais e as respostas às entrevistas foram organizados e trabalhados obedecendo às etapas descritas acima. Da mesma forma, organizei e dei tratamento aos dados obtidos através das diferentes técnicas utilizadas na fase 2, seguindo o mesmo procedimento.

Para auxiliar esta análise e o estabelecimento de relações entre as informações, utilizei também a triangulação de técnicas e de dados para analisar as informações coletadas, seguindo conceito e descrição propostos por Denzin (1970) e Patton (1990). Assim, os dados e as técnicas utilizadas foram analisados e comparados, agrupando-se os temas e assuntos inter-relacionados, buscando-se estabelecer a lógica por trás das informações acessadas.

A partir dessas etapas elaborou-se uma síntese ou uma conclusão para cada uma das fases do estudo, e a partir delas produziu-se uma conclusão geral, baseando-se também nos referenciais teóricos abordados nesta dissertação. 


\title{
4 RESULTADOS E DISCUSSÃO
}

\begin{abstract}
"Conservar, reconstruir, viver com a natureza são desafios à nossa inteligência e sensibilidade. Ainda que as árvores não tivessem a enorme utilidade e a decisiva importância que têm, por sua beleza e, sobretudo, por compartilharem conosco do maravilhoso mistério da vida, deveríamos, seres racionais e capazes de emoção que julgamos ser, admirá-las, respeitá-las e amá-las. (...) Continuo olhando minha canafístula. Penso na sua idade, na rigidez de seu tronco, na sombra, nas brincadeiras das crianças em torno do seu tronco. Ela e eu estamos entrelaçados, neste universo misterioso e pleno de vida"
\end{abstract}

A Magia das Árvores - Luis Rios de Moura Baptista

\subsection{Resultados e discussão da Fase 1:}

\subsubsection{Arborização urbana em Piracicaba: literatura científica e participação da universidade}

A consulta à literatura, mostra que poucos trabalhos científicos têm sido realizados com relação à arborização urbana em Piracicaba, sendo que nenhum deles envolvendo educação ambiental, embora todos destaquem a necessidade de se trabalhar neste sentido.

Em 1969, a Prefeitura do Município de Piracicaba solicitou ao CALQ (Centro Acadêmico Luiz de Queiróz) um estudo visando dar ao município subsídios para um planejamento técnico quanto ao sistema de arborização a ser adotado. Neste trabalho, os estudantes já apontavam a existência de uma arborização pobre, quase inexistente, com árvores plantadas sem obedecer a um espaçamento adequado e em locais normalmente impróprios para a espécie (Prefeitura Municipal de Piracicaba, 1969/1970).

Em 1976, Troppmair (p.69), realizando um estudo para verificar o índice de área verde na zona urbana de Piracicaba, chegou ao valor de $0,1 \mathrm{~m} / \mathrm{h} / \mathrm{bitante}$. Verificou 
ainda que, das 581 ruas analisadas na pesquisa, somente 32 eram arborizadas. Recomendou que no espaço já edificado, onde é difícil e extremamente dispendioso a criação de áreas verdes, deve-se proceder à arborização das ruas com espécies adequadas.

Posteriormente, Campos $^{4}$ (1988), chegou ao índice de 1,6 m2/hab. Para este cálculo o autor considerou os espaços livres de uso público de Piracicaba, concluindo que a cidade é extremamente carente de espaços livres.

Um pouco mais otimista, Lima et al. (1990, p.184) em seu estudo sobre o índice de áreas verdes na cidade abrangendo também os 8 distritos que compõem o município, chegou ao índice de $2,2 \mathrm{~m}^{2} /$ habitante, valor um pouco maior que o anterior, porém ainda baixo. A autora afirma que uma das diretrizes a serem tomadas para a melhoria deste quadro, passa por um planejamento que leve em conta a análise do meio ambiente e as aspirações da população.

Lima (1993, p.8), cita Carvalho (1982), cuja pesquisa com arborização urbana em Piracicaba, mostrou que em ruas arborizadas, o interior das residências tende a mostrar uma menor temperatura, tanto no período da manhã, como à tarde. Já em ruas desprovidas de arborização, além da temperatura mais elevada, externamente, no período da manhã, à tarde a mesma torna-se mais alta no interior das residências, chegando a uma amplitude térmica de mais de $3^{0} \mathrm{C}$.

Lima et al. (1993, p.555) fizeram uma análise das espécies mais freqüentes da arborização viária, na zona central de Piracicaba e constataram que existe uma predominância muito grande de uma única espécie, a Caesalpinia peltophoroides Benth., conhecida como Sibipiruna.

Uma tese de doutorado enfocando o assunto foi desenvolvida por Lima (1993) que, ao analisar a situação da arborização viária na região central de Piracicaba, percorreu 105,7 km de calçadas laterais e 6, $8 \mathrm{~km}$ de canteiros centrais. Encontrou 117 espécies num total de 4.904 árvores, e destas apenas 35 espécies perfaziam 95,6\% da

4 CAMPOS, S. A., Áreas verdes de Piracicaba. Trabalho de formatura, Instituto de Biociências/UNESP/Rio Claro, 1988, 37 p. 
população. Do total, 330 exemplares estavam mortos e a Sibipiruna - Caesalpinia peltophoroides Benth. - predominou em toda a área, representando 56,1\% do total.

Segundo a autora, os maiores problemas encontrados na arborização viária da cidade relacionaram-se ao grande número de indivíduos apresentando raízes que danificavam o calçamento (62,3\%), com área livre de solo, na região do colo da planta, insuficiente a seu desenvolvimento $(89,3 \%)$ e, indivíduos podados $(69,9 \%)$ ou presença de fiação aérea $(55,9 \%)$, podem ter resultado numa escolha pouco adequada das espécies quanto ao local de plantio, já que o indicador dessa condição apresentou, apenas, 27,5\% de indivíduos sob condições favoráveis. Também condições fitossanitárias mostraram-se preocupantes, totalizando $10,5 \%$ de plantas doentes e $17,4 \%$ de praguejadas (Lima, 1993, p. xvi- xviii).

Neste trabalho constatourse que as 35 espécies, encontradas nos canteiros centrais, totalizaram 447 plantas vivas e contribuíram com 7,7\% na diversidade das 117 espécies analisadas. Sob condição geral, bem melhor que a evidenciada para o calçamento viário, a arborização dos canteiros centrais apresentou como único agravante o uso excessivo da espécie - Syagrus romanzoffiana (Cham.) Glassman , popularmente denominada Jerivá (58,1\% do total de indivíduos).

Segundo a autora, os plantios recentes efetuados na área, pareceram repetir os mesmos erros de planejamento.

A autora recomenda que, "além de pesquisas à introdução de um maior número de espécies adaptáveis, torna-se imprescindivel o desenvolvimento de técnicas de manutenção mais adequadas com as árvores já existentes, sendo necessária, também, a participação direta e efetivo do Órgão Municipal, responsável pelo setor" (Lima et al 1993, p.xvi - xviii).

No ano de 2000 o grupo PET-Ecologia da ESALQ/USP em parceria com a Prefeitura Municipal de Piracicaba, realizou um "projeto de cunho social visando a educação ambiental no bairro Jardim Oriente, onde buscou-se a participação da comunidade local de modo a tornar os moradores confiantes na possibilidade de 
desenvolver o quadro ambiental do bairro, começando pela questão da arborização urbana" $^{\prime \prime}$.

Piracicaba abriga um campus de uma das maiores universidades do país, oferecendo dentre outros, os cursos de Engenharia Agronômica e Engenharia Florestal, porém a ESALQ tem tido pouca participação no planejamento da arborização da cidade, não se sabe se por falta de espaço e oportunidade ou por falta de interesse dos pesquisadores.

Não existe ainda nos dois cursos citados uma disciplina de graduação sobre silvicultura ou arborização urbana, e talvez a sua criação já aprovada pelo Conselho do Departamento de Ciências Florestais venha a trazer maiores contribuições para a cidade.

Esta ausência é criticada pelos técnicos entrevistados, alguns deles reclamando da postura crítica de alguns profissionais ligados à universidade sem as devidas contribuições que poderiam ajudá-los a corrigir deficiências.

A coordenadora do Viveiro Municipal reclama da falta de pesquisa com experimentação de espécies que poderia ser realizada pela universidade com a finalidade de subsidiar os projetos arborização. Em virtude da falta de experimentações ela afirma que algumas espécies têm sido recomendadas e distribuídas pelo viveiro de forma empírica.

Falando sobre a participação da universidade nas questões ambientais que envolvem as comunidades, Sorrentino (1997) reflete que

"no terceiro grau de ensino, torna-se cada vez mais marcante a necessidade de se formarem profissionais e cidadãos que atuem dentro de uma proposta de melhoria da qualidade de vida da população e de proteção, recuperação e melhoria das condições ambientais, sendo capazes de animar processos educacionais voltados à questão em outros graus do ensino e em outras instâncias de aprendizagem" (Sorrentino (1997, p.43).

\footnotetext{
${ }^{5}$ Informação obtida através do site http://www.pclq.usp.br/assessoria/grupos/pet.htm acessado em $07 / 11 / 2001$.
} 


\subsubsection{Gerenciamento da arborização viária em Piracicaba}

Num rápido passeio por alguns bairros de Piracicaba pode-se verificar que existe uma certa constância na presença de tocos de árvores cortadas ou uma saliência vazia na calçada onde antes havia uma árvore, ou mesmo marcas de cimentação nova eliminando qualquer esperança sobre intenção de replantio por parte dos moradores.

Alguns bairros como o Nova Piracicaba e o Jardim Europa diferenciam-se do cenário geral por apresentarem uma arborização mais rica e abundante, com espécies de grande porte em pleno desenvolvimento, porém estes bairros são exceção à regra. Alguns analistas acreditam que por serem considerados bairros de classe média alta, com o acesso facilitado à informações que possibilitem um nível de conscientização mais elevado, essa relação com as árvores seja mais positiva. Com relação à este fenômeno, pode-se buscar outras interpretações que possam explicá-lo, como por exemplo, o fato de que uma das vantagens da arborização urbana é a valorização econômica e paisagística que confere às residências, conforme relatado em capítulo anterior desta dissertação. Portanto, talvez mais do que uma consciência ecológica à respeito das árvores, é possível que este benefício seja percebido pela população residente nos bairros de classe média-alta, que freqüentemente utiliza os recursos de ajardinamento e paisagismo em suas residências. Um outro fato que pode estar relacionado a este fenômeno diz respeito aos espaços melhor dimensionados entre os imóveis e a calçada, preservando um espaço mais privilegiado para as árvores do que os espaços encontrados em bairros onde predominam casas sem recuo frontal. 


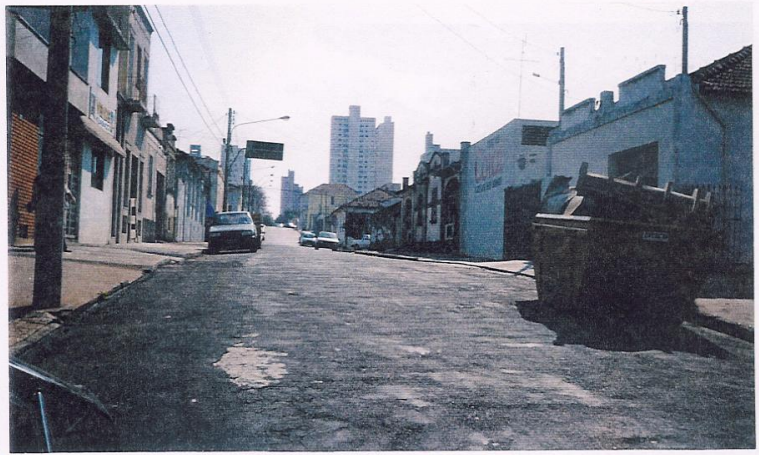

Figura 2 - Rua de Piracicaba praticamente desprovida de arborização.

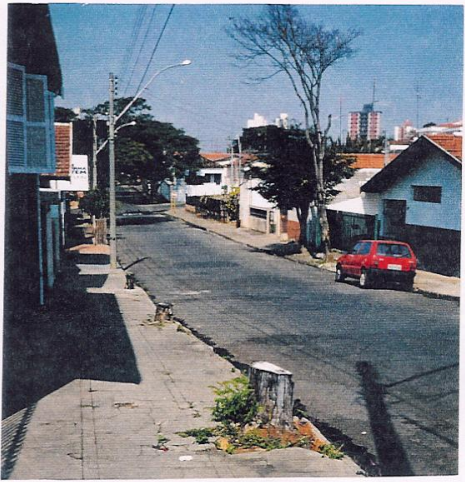

Figura 3 - Paisagem inóspita, tocos na calçada. 


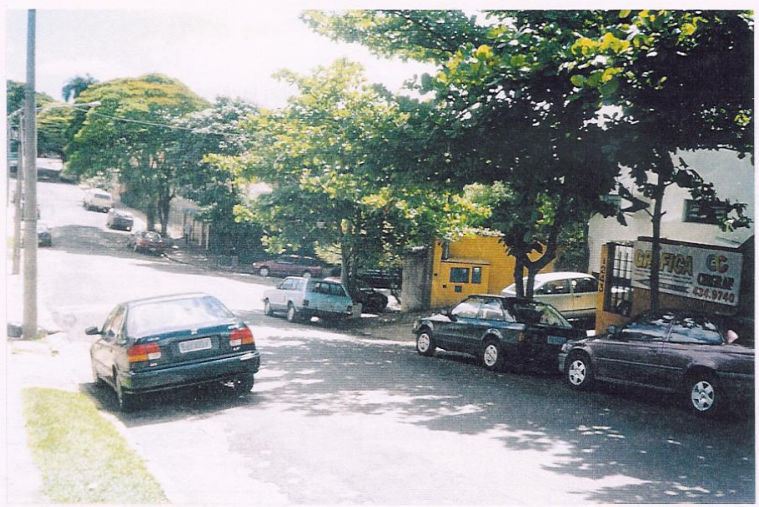

Figura 4 - Rua do Jardim Europa: árvores frondosas.

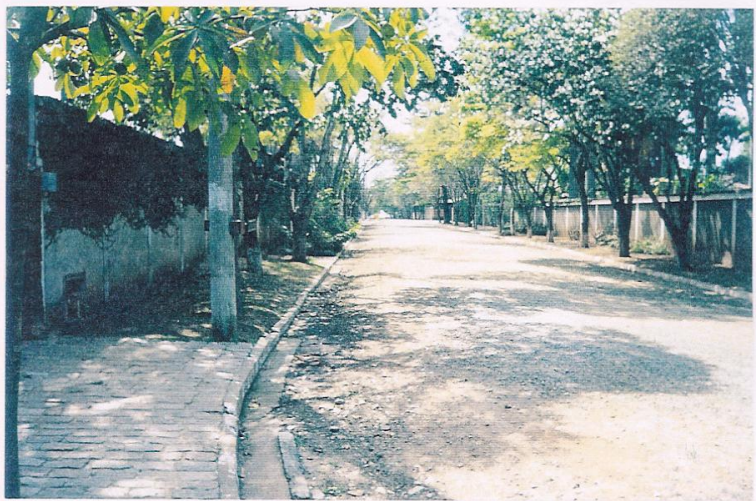

Figura 5 - Rua do bairro Nova Piracicaba: arborização abundante. 
O órgão responsável pelo gerenciamento e administração da arborização urbana em Piracicaba é a SEDEMA - Secretaria Municipal de Defesa do Meio Ambiente. Este órgão se subdividia até o meio do ano de 2000, época em que foi realizada a pesquisa de campo, em dois departamentos: um responsável pela limpeza pública, chamado Controle Ambiental, e outro denominado Ecossistemas, responsável por serviços públicos:

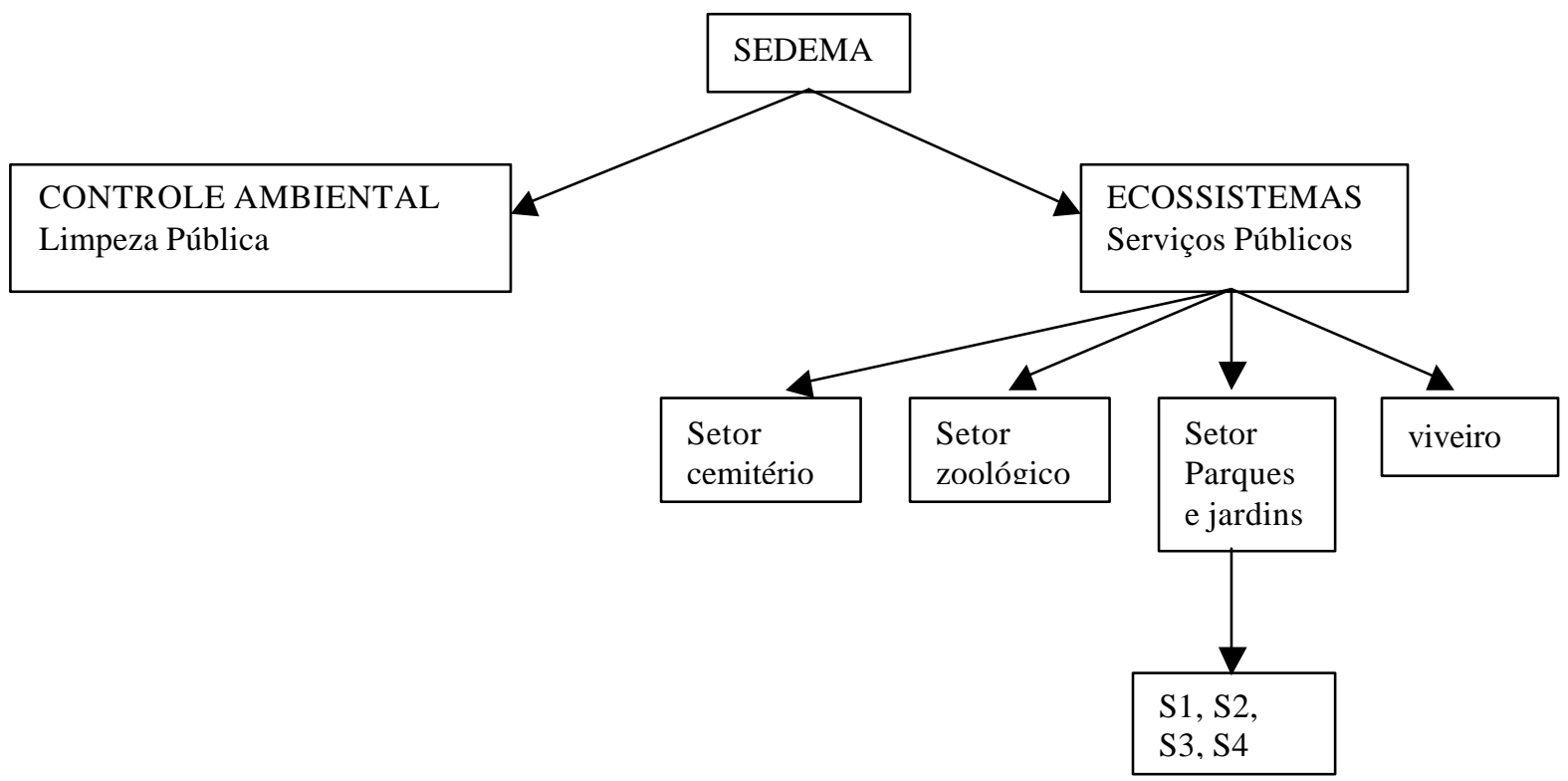

Figura 6 - Fluxograma da SEDEMA - Secretaria Municipal de Defesa do Meio Ambiente-Organograma de funcionamento - Ano 1999

As áreas verdes e a arborização na cidade eram gerenciadas pelo Setor Parques e Jardins, que se subdividia em quatro setores (figura 07):

Setor 1 - abrange a área central, caracterizando-se pela alta densidade populacional, 
presença forte de área comercial, casas sem recuo, ausência de terrenos baldios e solo raso.

Setor 2 - abrange a margem direita do rio Piracicaba (Bairro Santa Terezinha e outros).

Caracteriza-se pela diversidade de condições é considerada uma mini-cidade por sua complexidade.

Setor 3 - abrange os conjuntos habitacionais, regiões novas da cidade.

Setor 4 - abrange a periferia e os ribeirões. 


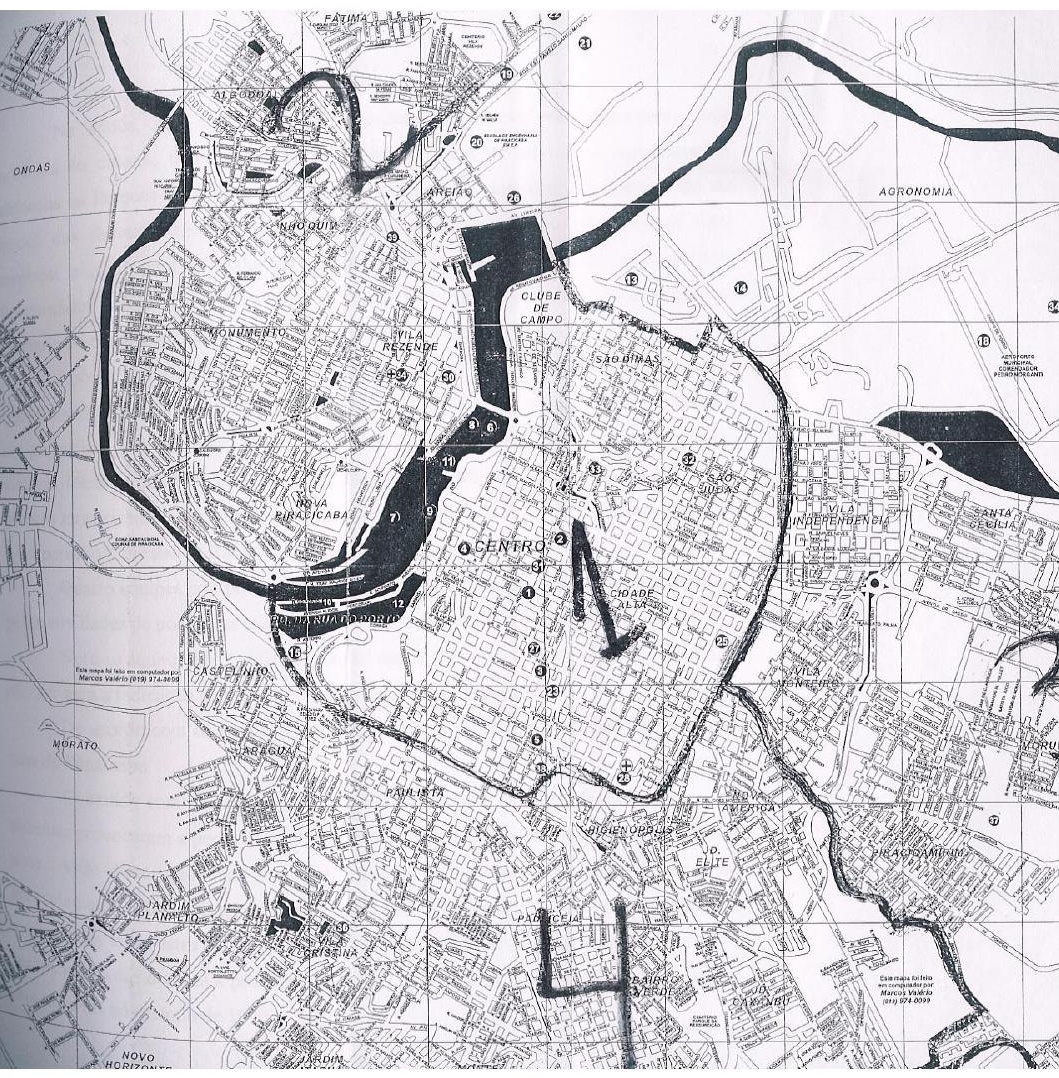

Figura 7-Mapa de Piracicaba, mostrando as divisões administrativas em setores 
Na época, não existia um departamento responsável especificamente pela arborização urbana, ficando os setores sobrecarregados de atividades, concentrando esforços na limpeza de praças, áreas verdes, margens de rios, etc, que por ocasião da época das chuvas exigem grandes esforços no controle do mato. Essa época seria também a ideal para as ações de plantio, porém com os técnicos e os demais funcionários dos setores concentrados na limpeza do mato, pouca atenção era dada ao incremento e melhoria da qualidade da arborização da cidade.

Após o período de pesquisa de campo, esta estrutura foi modificada, e o novo coordenador nos informou que, a partir de Junho de 2000, a arborização urbana passou a ser gerenciada por um único departamento, que agora concentra todas as atividades de vistoria técnica, podas e supressão, em toda a área urbana, ficando as atividades de plantio terceirizadas, sob responsabilidade de uma ONG, a FLORESPI (Associação de Recuperação Florestal da Bacia do Piracicaba e região).

Quatro equipes compõem agora o departamento, sendo duas delas responsáveis pelas atividades de poda, e as outras duas responsáveis pelos cortes de árvore.

Note-se aqui que os técnicos do setor não se envolvem na atividade de plantio, a não ser para a indicação de espécies, ficando esta a cargo de terceiros.

De acordo com os técnicos não existe uma estatística da população arbórea das ruas de Piracicaba.

Contando com um sistema de informática bastante precário, falhas e panes nos sistemas provocaram a perda de muitos dados sobre a arborização da cidade nos últimos anos. Além disso, cada um dos quatro setores antes existentes, adotou formas de gerenciamento autônomas, não havendo uma sistematização e convergência de informações entre estes setores. Alguns dados puderam ser coletados nas entrevistas e visitas realizadas durante a pesquisa. $\mathrm{O}$ quadro 01 mostra o número de árvores cortadas das calçadas no período de 1990 a 1999. 


\begin{tabular}{|l|r|}
\hline ANO & $\begin{array}{l}\text { No. Árvores } \\
\text { Suprimidas }\end{array}$ \\
\hline 1990 & 335 \\
\hline 1991 & 356 \\
\hline 1992 & 350 \\
\hline 1993 & 1.758 \\
\hline 1994 & 1.820 \\
\hline 1995 & 2.272 \\
\hline 1996 & 1.880 \\
\hline 1997 & 1.333 \\
\hline 1998 & 906 \\
\hline 1999 & 1.096 \\
\hline Total & 12.106 \\
\hline
\end{tabular}

Fonte: SEDEMA - Secretaria Municipal de Defesa do Meio Ambiente - 2000

Quadro 1 - Número de árvores cortadas, de 1990 a 1999.

A inexistência de um inventário da população arbórea da cidade dificulta os trabalhos de manutenção e planejamento da arborização urbana da cidade. Takahashi (1994, p. 193-198) assim descreve os objetivos gerais de um inventário do patrimônio arbóreo de uma cidade:

". conhecer o patrimônio arbóreo;

. definir uma política de administração a longo prazo;

. estabelecer previsões orçamentárias para o futuro;

. preparar um programa de gerenciamento das árvores;

. identificar necessidades de manejo;

. definir prioridades nas intervenções;

. localizar áreas para plantio;

. localizar árvores com necessidade de tratamento ou remoção;

- utilizar a árvore como um vetor de comunicação" (Takahashi, 1994, p.193198). 
Além da inexistência do inventário da população arbórea da cidade, outro fator a dificultar o planejamento e a gestão da arborização é a desarticulação entre este setor e os diversos outros encarregados do planejamento urbano, conforme relatado pelos técnicos.

\subsubsection{Pressões políticas: cortes de árvores $=$ "Indústria de votos"}

Observados do ponto de vista das gestões políticas, podemos identificar uma tendência mais preservacionista durante os três primeiros anos apontados no quadro anterior, sendo que a partir daquele ano o número de árvores suprimidas nas ruas da cidade aumentou expressivamente. Reunidos, os números mostram o seguinte quadro:

\begin{tabular}{|l|r|r|}
\hline Período & $\begin{array}{l}\text { No. de árvores } \\
\text { Suprimidas }\end{array}$ & Gestão política \\
\hline $1990-1992$ & 1.041 & PT \\
\hline $1993-1996$ & 7.730 & PSDB \\
\hline $1997-1999$ & 3.335 & PSDB \\
\hline TOTAL & $\mathbf{1 2 . 1 0 6}$ & \\
\hline
\end{tabular}

Fonte: SEDEMA - Secretaria Municipal de Defesa do Meio Ambiente - 2000

Quadro 2 - Número de árvores suprimidas de acordo com as gestões políticas

Os depoimentos coletados entre engenheiros e profissionais que acompanharam as políticas para o setor durante o período abordado, confirmam a tendência apontada.

"(...) Por volta do ano de 1989 havia uma política 'preservacionista' por parte da prefeitura, no intuito de desestimular a população a cortar as árvores, sendo que a alegação era realmente verdadeira: falta de estrutura e acúmulo de 
pedidos. O processo era muito vagaroso, demorava cerca de dois anos, e isso acabava barrando a onda de desmatamento que veio assolar a cidade posteriormente" - relato de um engenheiro.

Segundo este profissional, em 1993 mais dois impedimentos vieram somar-se àqueles:

"um artifício burocrático: Toda solicitação de corte que fosse em locais de obras, teria que passar por um órgão municipal que administrava obras em imóveis, e como havia um grande número de obras clandestinas (irregulares), o morador optava por não suprimir a árvore, a fim de evitar a visita de fiscais. $O$ outro artifício empregado foi a cobrança para retirada da árvore. Deste modo, represou-se um pouco os pedidos de corte.

"Já em 94-95, o prefeito manda equipar o setor e abaixa o preço para a retirada de árvores, facilitando todo o processo".

"Em 96, os cortes aumentaram absurdamente. O atendimento aos inúmeros pedidos de supressão de árvores transforma-se numa verdadeira 'indústria de votos'", na fala do engenheiro.

Os engenheiros responsáveis pelos setores passam a sofrer fortes pressões para acelerar processos de supressão. Pressionados, de um lado por políticos, que vêem no atendimento dos pedidos de corte uma "indústria de votos" e por uma parcela da população que solicita o corte de árvores, e do outro por ambientalistas e moradores que se posicionam contra os cortes de árvores viárias, os técnicos reclamam.

"Sofremos pressões até dentro de nossas casas, nos horários de descanso! Outro dia um vereador ligou às 22:00 pra minha casa, pedindo para aprovar e acelerar um processo de supressão, e o pior é que ele era do PV (Partido Verde)!', desabafa uma engenheira agrônoma.

Ao visitarmos o novo departamento responsável pela arborização urbana, notamos que o telefone não parava de tocar, quase sempre algum morador solicitando mais um corte de árvore. Agora concentradas num só setor, as informações passam a ser sistematizadas, e desta forma tivemos acesso ao número de pedidos de corte que chegaram ao SEDEMA durante os meses de Agosto a parte de Outubro de 2000: 


\begin{tabular}{|l|c|}
\hline MÊS (2000) & $\begin{array}{c}\text { No. de pedidos } \\
\text { de corte }\end{array}$ \\
\hline Agosto & 233 \\
\hline Setembro & 438 \\
\hline Outubro (até dia 10) & 82 \\
\hline Total & $\mathbf{7 5 3}$ \\
\hline
\end{tabular}

Fonte: SEDEMA - Secretaria Municipal de Defesa do Meio Ambiente - 2000

Quadro 3 - Solicitações de corte de árvores na cidade durante os meses de Agosto a Outubro (parcial) de 2000:

De acordo com o coordenador do setor, cerca de 1 a $2 \%$ destes pedidos são indeferidos, sendo o restante atendidos após vistoria técnica.

Pode-se notar que os pedidos de corte, que serão praticamente todos atendidos, durante estes três meses, correspondem aos cortes realizados em três anos de mandato político da primeira gestão analisada no quadro 02 .

Verifica-se também que estes meses antecedem as eleições para prefeito e vereadores de 15 de Novembro de 2001, quando normalmente este tipo de favorecimento é bastante comum na disputa por votos.

Houve até um caso digno de ser comentado, em que um sobrado de esquina teve várias sibipirunas cortadas, fato que originou uma matéria-denúncia de primeira página num jornal da cidade. Cerca de um mês após, uma enorme placa foi "plantada" em seu quintal, agora livre do impedimento visual provocado pelas copas das árvores, oferecendo às vistas dos passantes a imagem de um candidato à vereador.

\subsubsection{Critérios técnicos para corte de árvores viárias}

Ao receber a solicitação de corte, a SEDEMA envia um técnico ao local para realizar uma vistoria a fim de comprovar a necessidade de supressão, onde alguns 
critérios são avaliados. Estes critérios são pré-estabelecidos, e o técnico vai assinalando aqueles que correspondem à situação observada. A seguir é emitido um Laudo de Deferimento ou Indeferimento, dependendo da avaliação do técnico.

Analisou-se 170 Laudos de Deferimento (autorização) à solicitações de corte e verificou-se que os casos para corte distribuíam-se entre os seguintes critérios:

- Afetando a calçada:170 casos - 100\%

- Afetando a rede elétrica: 90 casos - 52,9\%

- Causando entupimento de calhas : 75 casos - 44,1\%

- Afetando a estrutura do imóvel: 65 casos - 38,2\%

- Apresentando estado fitossanitário comprometedor: 35 casos - 20,5\%

- Impedindo entrada de veículos : 21 casos - 12,35\%

- Plantada junto ao poste: 13 casos - 7,64\%

Constata-se aqui que alguns critérios muito questionáveis são considerados na maioria dos casos de deferimento para corte, como o fato de afetar a calçada e causar entupimento de calhas. Considero-os muito questionáveis devido ao fato de se configurarem a meu ver, como questões intrinsicamente culturais, e que tecnicamente poderiam ser solucionados sem o sacrifício da árvore.

No caso da quebra de calçadas, o que se constata na prática é que a área deixada ao redor do colo da planta, é na maioria das vezes insuficiente, ou em muitos casos inexistente, com a cimentação a envolver completamente o caule da árvore. Seria óbvio prever que as raízes da árvore, durante o seu desenvolvimento, normalmente deverão provocar rachaduras na calçada; entretanto moradores e técnicos que fazem as recomendações de plantio parecem não perceber tal obviedade.

A seguir, reproduzo um trecho da entrevista realizada com um engenheiro especialista em arborização urbana, onde falamos sobre o tema:

Engenheiro: Você sabe o que precisa fazer? Precisa trabalhar como uma cultura... tratar a arborização como uma cultura. Então quando você vê o pessoal plantando muda de... qualquer planta aí, em calçada especialmente, faz-se o que? Faz-se uma 
cova de 30 x 30, e enfia-se a muda lá no lugar. A planta ela precisa de um espaço de solo pra ela poder desenvolver o sistema radicular. $O$ solo urbano já é um solo completamente diferenciado dum solo agrícola. Ele não tem um perfil... ele tem restos de entulho, restos de construção, é todo alterado. Então a questão de as raízes das árvores estourarem calçada é uma resposta à condição indevida do solo. Então eu te pergunto, já que você tá pesquisando, cê viu alguém plantar muda em cova de padrão? Até agora? Daí cê fala, o que que é cova de padrão? Cova de padrão é a maior possível... e o que que é maior possível... no mínimo $60 \times 60 \times 100$. Onde que a gente vê isso?

Pesquisadora: eu fotografei aquela Sibipiruna enorme em frente do Centro Espírita União, que já deve ter décadas de idade, e a calçada em volta dela está intacta. Então pra mim isso é uma prova de que existe maneiras corretas de se plantar...

Engenheiro: Isso mesmo, agora, a primeira reação que as pessoas têm também à quebra da calçada é cortar raiz. Cortar raiz superficial... Daí cê vai ver aonde tá ocorrendo a quebra, é onde você tem um canteiro pequeno. Normalmente o canteiro é pequeno, aí cê fala pra pessoa "a solução aqui não é você cortar a raiz, a solução aqui é você ampliar o canteiro...

Pesquisadora: claro... inclusive pra não impermeabilizar toda a cidade como tá acontecendo né?

Engenheiro: claro... então, você vê a própria Av. Independência ela foi... antes ela era assim, ida e vinda... não tinha esses bolsões de estacionamento. Daí a prefeitura...foi feita essa ampliação, foi instalado esses bolsões, né? esses boxes de estacionamento e muitas árvores foram retiradas. Tudo bem, a arborização era velha, diga tudo isso daí. Mas teve um monte de árvore... a esse título teve tanta árvore que foi pro embrulho também que você tem que ver... e outra... se você passar em qualquer trecho da avenida aí... é bom observar, onde não tem a calçada, tem asfalto, tem a árvore no asfalto, o asfalto chega até o colo dela... Poxa, existe uma relação de solo/sistema radicular e ar, e água, que tá deixando de existir!... Essas plantas tão recebendo água somente pela copa quando chove... cê já imaginou isso? E elas tão vivas ainda, elas tão sobrevivendo. Porque? Porque elas foram ... elas atingiram alguma camada de lençol que tem água. Mesmo essas menores... então, o sistema radicular, ele se adapta, ele vai buscar água onde a planta precisa. Árvore é assim. Agora a primeira medida que a pessoa, que o cidadão adota é cortar o sistema radicular e depois cobrir ali pra não ficar... ah, que é isso!... Quais são as funções da raiz? A primeira função da raiz é estabilizar... a Segunda é função nutricional. Então, ser o alicerce, quer dizer a função estabilizadora, ela deixa de existir. Daí começa a falar "pô, mas porque que tá caindo tanta árvore?” Tá caindo porque a raiz foi cortada. Existe uma relação de proporcionalidade, de equilíbrio mínimo entre a parte aérea e o sistema radicular. E porque que a planta faz isso? Porque a cova não foi preparada devidamente quando foi plantada a muda. 
Além destes fatos, destaca-se também a importância demasiada que a população dá ao calçamento em detrimento da arborização. Do ponto de vista cultural e ambiental isto poderia ser considerado como uma grande inversão de valores. $\mathrm{O}$ calçamento excessivo de uma cidade acaba por torná-la completamente impermeável às águas pluviais, que em época de chuvas abundantes, acabam por não infiltrar-se no solo, escorrendo para as partes mais baixas da cidade, acarretando em inundações e tragédias das mais variadas proporções.

Uma outra entrevista realizada com um político militante do Partido Verde na cidade, que posteriormente tornou-se secretário do municipal do meio ambiente, revelou que a legislação municipal além de não incentivar, acaba por impedir a adoção das chamadas "calçadas verdes" (figura 08), recurso muito utilizado em países como Canadá e algumas cidades dos Estados Unidos e Europa. Segundo ele, o "habite-se", documento que regulariza o imóvel, pela legislação do município, só é expedido após a cimentação completa da via pública em frente à propriedade. "Existe até um bairro novo aqui na cidade em que os moradores optaram por ter "calçadas verdes" e para burlar a lei, utilizam uma camada bem fina de cimentação da calçada, facilmente removível para, após conseguirem o "habite-se", procederem à sua quebra e substituição pelo elemento verde.", exemplifica o político.

Quanto ao problema do entupimento de calhas, de acordo com informações de especialistas na área, em outras cidades do estado de São Paulo, tem sido contornado através da colocação de uma tela protetora sobre a calha. Além desta solução, muitos moradores resolvem o problema facilmente através de uma limpeza semestral da calha.

Ao escolher privilegiar o calçamento viário ou a limpeza da calha ao invés da árvore, a população abre mão de todo o benefício ambiental proporcionado pela arborização urbana, conforme já descrito no capítulo anterior. Esta inversão se configura como uma questão intrinsicamente cultural, que poderia ser tratada com maior seriedade pelos planejadores urbanos, no que diz respeito ao aspectos técnico, educativo e de legislação.

Além das críticas que fazemos aos critérios acima destacados, questionamos também o critério "afetando a rede elétrica", segundo lugar na lista de argumentos 
utilizados para suprimir-se árvores viárias em Piracicaba. Mais adiante, mostraremos soluções encontradas por outros centros urbanos, demonstrando que mesmo aqui existem soluções técnicas viáveis, mas que dependem de um posicionamento mais firme e menos submisso por parte dos responsáveis pelo planejamento e administração da arborização viária da cidade, frente aos argumentos utilizados pela CPFL.

\subsubsection{Espécies mais afetadas de acordo com os laudos examinados:}

Muitas vezes, um único pedido de corte diz respeito a mais de um indivíduo arbóreo e assim verificamos que as espécies sacrificadas nestes 170 casos foram as seguintes:

\begin{tabular}{|l|c|}
\hline Nome Vulgar & No. de indivíduos \\
\hline Sibipiruna & 175 \\
\hline Ipê & 25 \\
\hline Chapéu-de-Sol & 23 \\
\hline Tipuana & 14 \\
\hline Fícus & 08 \\
\hline Flamboyant & 01 \\
\hline Espatodia & 07 \\
\hline Outros & 08 \\
\hline TOTAL & $\mathbf{2 6 1}$ \\
\hline
\end{tabular}

Fonte: SEDEMA - Secretaria Municipal de Defesa do Meio Ambiente - 2000

Quadro 4 - Espécies Sacrificadas em 170 Laudos de Deferimento examinados 
Observa-se através do quadro 04, que a grande vítima dos cortes é a Sibipiruna, seguida pelos Ipês e pelos Chapéus-de-sol, todas árvores de grande porte e caducifólias (trocam sua folhagem em determinadas épocas do ano).

A seguir reproduzo um "desabafo" emitido por um especialista:

Engenheiro: "O que eu acho interessante é o seguinte, todo mundo quer, enquanto não tem problema. Agora vem problema, sabe, divorcia, 'não quero mais saber de você'. E a hora que faz falta todo mundo quer de volta, assim, chega no inverno, né? vou citar o caso da sibipiruna de novo, chega no período de inverno aí, ou quando cai a temperatura, né? no período aí de repouso vegetativo da planta, ela derruba as folhas...e tá renovando, né? A implicância que as pessoas têm com a tal da folhinha da sibipiruna... é impressionante. Ninguém se habilita a colocar na parte superior... na parte de cima das calhas, uma tela, ou alguma coisa pra proteger do entupimento de calha, ou da calçada, da sujeira, tudo isso daí. Mas quando chega no período de verão intenso, quando o sol é muito forte e o calor... todo mundo se lamenta porque não tem sombra, então uma árvore dessa ela tá se prestando pra essa finalidade num determinado período, né?

\subsubsection{Falhas de manejo comprometem saúde de Sibipirunas e demais espécies de grande porte}

As grandes vítimas dos cortes na cidade como demonstrou-se anteriormente, são as Sibipirunas e outras espécies de grande porte. Muitas vezes os técnicos alegam a necessidade do corte pelo comprometimento do estado fitossanitário da árvore.

De acordo com a tese de doutorado sobre a arborização viária da cidade (Lima, 1993), citada no início deste capítulo, os maiores problemas encontrados na arborização viária da cidade relacionaram-se ao grande número de indivíduos apresentando raízes que danificavam o calçamento $(62,3 \%)$, com área livre de solo, na região do colo da planta, insuficiente a seu desenvolvimento $(89,3 \%)$ e, indivíduos podados $(69,9 \%)$ ou presença de fiação aérea $(55,9 \%)$. Todas estes problemas evidenciam falhas o erros de planejamento e manutenção desta arborização.

O relato de um engenheiro levanta a hipótese de que a saúde das Sibipirunas da cidade foi comprometida por podas mal feitas: 
Engenheiro: (...) a qualidade (dos serviços de poda) não é boa... sabe? Embora tenha algumas pessoas daquela época que ainda trabalham... esses trabalham certinho... Mas assim, a qualidade não é boa, tendo em vista que as árvores da cidade de um modo geral, elas tão num estágio assim... árvores que vinham sendo trabalhadas, elas estão num estágio de desenvolvimento, num estágio da vida delas, que é muito avançado em relação àquela situação em que se pudesse recuperá-la... então, o manejo foi tão errado no passado que tem uma população dessas árvores que estão na cidade hoje que não dá pra você recuperar mais... Porque? Por causa do manejo errado antigo. Agora, eu asseguro uma coisa a você, na época em que nós estávamos aí nós éramos bem pela preservação. E eu vou fazer uma crítica: hoje, é muito mais fácil retirar uma árvore na cidade do que podar.

E eu acho assim, também, uma boa parte dos problemas em relação à árvores podadas é porque elas são podadas inoportunamente".

Pesquisadora: O que você chama de inoportuno?

Engenheiro: Eu chamo quatro coisas: primeiro, é você respeitar a espécie, segundo, você respeitar a idade da árvore, terceiro, você respeitar o ciclo reprodutivo da planta e quarto você respeitar o quanto, a quantidade e intensidade da poda. Se as pessoas, pelo menos os podadores, né? ou o poder público respeitasse essas quatro coisas em termos de poda, as árvores, elas não sofreriam tanta alteração no ciclo reprodutivo como elas têm hoje. Numa mesma época, num mesmo dia você vê, pega a mesma sibipiruna, se você sair hoje pra cidade você vê sibipiruna florida, você vai ver sibipiruna renovando folha, você vai ver sibipiruna completamente sem folha nenhuma, então, você vai ver... o que que é isso daí? Isso daí é desordem, pô, é desordem ambiental. Porque? Porque o manejo é errado. Qualquer espécie aí que você pega, vai ver numa mesma espécie a fase fenológica do desenvolvimento da planta, numa mesma data, ela é diferenciada... né? Porque? Porque o manejo é errado.

E outra, os conceitos de poda estão completamente errados, o pessoal puxa pra... passa pra árvore de cidade, conceito de poda de árvore frutífera. Não tem nada a ver. Completamente diferente. E tem os que são radicalmente contra a poda. Mas, assim, então dê outra solução... Falam assim, "ah, poda é um negócio que não devia existir" Por que existe? Existe porque a árvore foi escolhida errada. Porque a árvore foi mal colocada. Agora, se podar não é correto, eliminar é mais incorreto ainda. Então, Piracicaba tá assim, eliminar... sob um ponto de vista é um baita dum erro, né? Quer dizer, o problema se elimina com a retirada? De jeito nenhum. É preferível conviver com o problema e gozar dos benefícios. Eu acho assim".

E mais adiante critica:

Engenheiro: (...) o pessoal acaba generalizando. Poda não é generalização. Poda, você tem que respeitar a planta como indivíduo, não é pegar uma mesma rua, todas 
elas do mesmo... mesmo que seja da mesma espécie. Se você pegar a avenida Independência, tá cheio de Sibipiruna, será que todas elas... pra efeito assim de condução elas devam passar pelo mesmo processo? Não, porque a árvore tem que ser analisada individualmente, e a pressa não deixa ser individual, o tratamento. A pressa porque? Porque existe um fator importante em jogo que é o interesse financeiro. Por que alguém que tá fazendo poda, tá vendendo esse trabalho. Hoje, tendo em vista a terceirização dele, tá? Então, quem tá executando acaba executando errado por causa do interesse financeiro. Então tem que dar produção, e a produção, determina erro. Não dá padrão."

Além das podas, o tamanho das covas e a falta de espaço deixado pelo calçamento para o desenvolvimento das árvores, conforme já discutido anteriormente comprometeram seriamente a saúde das plantas, que atualmente precisam ser sacrificadas para evitar o risco de quedas.

A observação em campo mostra que nos novos plantios, quando estes ocorrem, existe a tendência a se repetir os mesmos erros.

\subsubsection{Novos plantios e espécies utilizadas: submissão às regras da CPFL e do mercado}

De acordo com um relatório da SEDEMA, o número de árvores plantadas em calçadas entre os anos 1997 e 2000 foi o seguinte:

\begin{tabular}{|l|c|}
\hline $\begin{array}{c}\text { Setor } \\
\text { administrativo }\end{array}$ & $\begin{array}{c}\text { No. de árvores plantadas em } \\
\text { calçadas }\end{array}$ \\
\hline Setor 1 & 525 \\
\hline Setor 2 & Não há dados. \\
\hline Setor 3 & 598 \\
\hline Setor 4 & 2.323 \\
\hline Total & $\mathbf{3 . 4 4 6}$ \\
\hline
\end{tabular}

Fonte: SEDEMA - Secretaria Municipal de Defesa do Meio Ambiente - 2000

Quadro 5 - No. de árvores plantadas em calçadas no período de 1997 a 2000. 
Se observarmos no quadro 01, o número de árvores cortadas em calçadas da cidade nos anos de 1997 a 1999, excluindo-se o ano 2000, chegou a 3.335. Ao adicionar-se os números do ano de 2000 (não disponíveis no relatório fornecido pela SEDEMA), provavelmente este número excederá o de árvores plantadas (quadro 05 ). Este fato é agravado por estar-se retirando na maioria das vezes, árvores de grande porte, substituindo-as principalmente por espécies de pequeno e médio porte.

Foram solicitadas ao Departamento de Ecossistemas informações mais detalhadas, como relatório de plantio por espécies e plantios efetuados nos anos anteriores, porém estes dados não estavam disponíveis.

É possível ter idéia do que vem se plantando nas calçadas da cidade através de uma lista de produção de espécies pelo Viveiro Municipal, que fornece as mudas utilizadas nos plantios (Apêndice 06). Constam desta relação as seguintes espécies:

“Canelinha, Cassia cinza, Chapéu-de-Napoleão, Espirradeira branca, Espirradeira rosa, Espirradeira vermelha, Esquinus molle, Flamboyanzinho, Hibisco amarelo, Ipê amarelo (T. crysotricha), Magnólia amarela, Manacá da serra, Monguba, Murta, Oiti, Pitanga, Pitanga Preta, Quaresmeira rosa, Quaresmeira roxa, Resedá branco, Resedá rosa e Resedá lilás".

De acordo com o "Guia de Arborização" editado pela Cesp, largamente utilizado pelas prefeituras municipais no estado de São Paulo, desta relação, a Magnólia amarela , o Ipê amarelo, a Monguba e o Oiti são consideradas espécies grandes, com mais de 6 metros de altura. Já a Quaresmeira, o Resedá e a Espirradeira são consideradas espécies ornamentais médias, com 4 a 6 metros, enquanto que o Flamboyanzinho, o Manacá, o Hibisco, a Cassia e a Murta (figura 09) são espécies ornamentais de porte pequeno, com menos de 4 metros.

O Schinus molle (Aroeira-salsa) pode atingir de 4 a 8 metros e a Canelinha (Nectandra megapotamica), de 15 a 25 metros de altura (Lorenzi, 1992).

Nota-se que somente uma espécie frutífera é oferecida pelo viveiro, a Pitangueira, enquanto que a Espirradeira, em suas várias colorações e o 
Flamboyanzinho, que possuem elementos altamente tóxicos aos seres humanos, são largamente utilizados nos plantios recentes.

Neste ponto reside um dos meus grandes questionamentos, pois é incompreensível e incoerente constatar que na literatura e nos simpósios e congressos da área, existe um grande número de pesquisadores e profissionais que condenam a utilização de plantas frutíferas na arborização urbana, sob a alegação de que estas são susceptíveis à depredação, provocam aglomeração de pessoas (principalmente do público infantil, suponho), podem ser hospedeiras de doenças e pragas que podem afetar pomares comerciais, ou que a queda de seus frutos podem danificar veículos ou ferir os transeuntes. Alguns destes mesmos pesquisadores e profissionais, conforme pude constatar num seminário ocorrido na ESALQ e também através das entrevistas e conversas, não hesitam em indicar espécies tóxicas para a arborização urbana.

"Árvore não é salada!" argumenta uma engenheira agrônoma, e uma reflexão fica pairando: quantas crianças são conscientes disso? Não seria muito mais razoável, coerente e até "humano" evitar expor a população ao risco de uma intoxicação grave como a que pode ser provocada pelo leite venenoso da Espirradeira, e ao invés disso propiciar às crianças, hoje tão carentes de quintais e árvores em suas vidas, a possibilidade de deliciar-se com algumas frutas "colhidas no pé", o que por si mesmo já seria um elemento altamente educativo?

Um outro ponto que se observa nesta análise do que vem sendo plantado nas ruas da cidade é uma tendência à submissão às regras ditadas pela CPFL, onde a arborização urbana é que deve ajustar-se ao equipamento elétrico, e desta maneira a utilização de arbustos e árvores de pequeno porte sob fiação.

Atualmente, verifica-se nas ruas da cidade que uma população grande de Sibipirunas vem sendo sacrificada, e em seu lugar, quando existe o replantio, tem-se plantado espécies de pequeno porte, de pouco efeito ambiental, na maioria das vezes, como as murtas, as espirradeiras e os hibiscos, por exemplo. Essa tendência, que não pode ser comprovada numericamente por falta de sistematização de dados pelo órgão responsável pelo setor, é confirmada pelos depoimentos dos engenheiros responsáveis pelo planejamento da arborização da cidade. 
Um dos engenheiros relata que considera a

"arborização urbana em Piracicaba inadequada, muitos problemas ocorreram, e existem as mudanças acontecendo. Hoje pergunta-se 'quem foi que encheu a cidade de sibipiruna?, daqui há 30 anos pode-se perguntar 'quem foi que encheu a cidade de arbustos?"

Chegam a admitir erro na utilização de árvores de pequeno porte e arbustos predominantemente nos plantios recentes, como vem ocorrendo. "Poderia haver mais utilização de espécies maiores mesmo sob fiação, desde que passíveis de poda", avalia uma engenheira. Outra engenheira considera que "lugar de árvore de grande porte é em áreas verdes, e não no calçamento viário". Porém a cidade possui poucas áreas verdes.

A seguir reproduzo trecho da conversa com um engenheiro que foi assessor do órgão responsável em anos anteriores:

Pesquisadora: Voltando àquela época que você tava assessorando a prefeitura, né? como consultor, na verdade, né? Vocês fizeram um programa de seleção de novas espécies também? E que espécies que vocês definiram no programa?...

Engenheiro: (...) Nós eliminamos todas as árvores de porte grande e introduzimos árvores de porte pequeno, de porte baixo.

Pesquisadora: De porte baixo, só. Mas você acha que isso resolve o problema da arborização?

Engenheiro: Não de arborização não resolve, mas sob fiação resolve. Pesquisadora: Mas aí não tá virando uma panacéia?... todo mundo tá plantando árvore de baixo porte, inclusive onde não há fiação... a gente vê hibisco, vê uma série de arbustos, falsa murta... espalhados pela cidade toda... Engenheiro: certo... certo... a idéia é utilizar essas espécies só sob fiação. E no lado oposto à fiação, utilizar árvore de porte maior.

A maioria dos profissionais entrevistados confirmam a existência de modismos seguidos pelas prefeituras e moradores nas cidades, ao que chamam de "febre de Sibipirunas", " febre de Bauínias", " febre de Aroeira Salsa", "febre de Ficus" e assim por diante. Desta forma, pode-se perceber que os próprios técnicos responsáveis pelo planejamento da arborização viária da cidade, questionam-se sobre a escolha de espécies utilizadas nos plantios recentes, e que não existe um consenso 
sobre o assunto entre eles, que acabam cedendo à pressões da CPFL e à tendências ditadas pelos viveiristas e o mercado de mudas. 


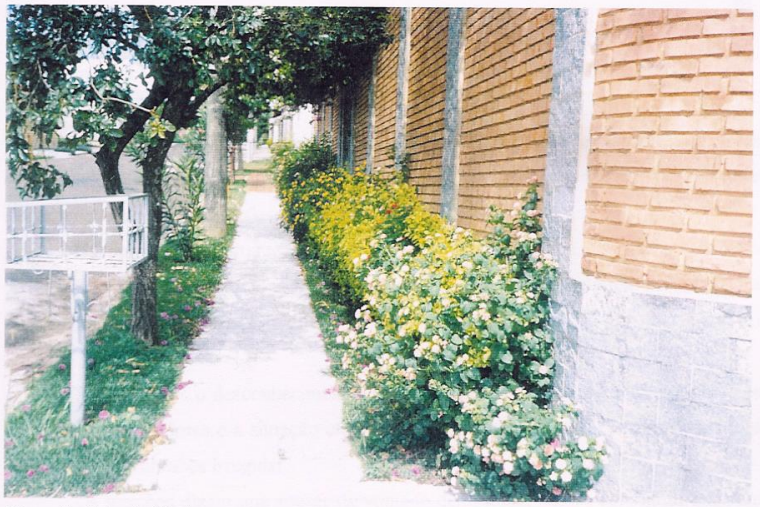

Figura 8 - Calçada Verde.

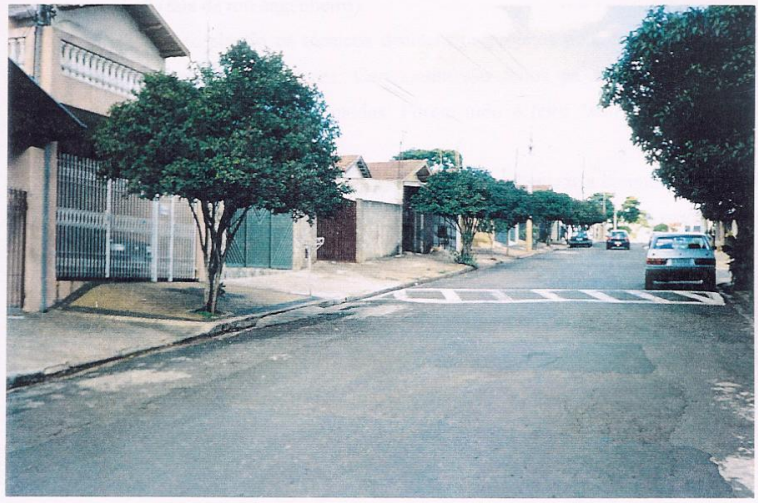

Figura 9 - Rua arborizada com Falsa Murta. 


\subsubsection{Projetos e campanhas educativas}

Segundo os depoimentos recolhidos entre os técnicos, os problemas ou as dificuldades fundamentais em arborização urbana envolvem "educação da população e manutenção da arborização".

Na opinião de militantes do Partido Verde em Piracicaba, a ausência de uma arborização mais abundante na cidade se deve à tradição cultural de não se enxergar a árvore como ser vivo, à falta de orientação ( qual árvore é boa, como trabalhar a árvore) etc.

Segundo eles o desconhecimento das leis também é um fator que pesa sobre as atitudes dos moradores e a situação atual da arborização na cidade, e em sua opinião a prefeitura faz cobrança irregular.

Os técnicos dizem que apesar da vontade deles ainda não se conseguiu criar um Plano Diretor para a arborização da cidade. "Hoje as ações são desordenadas para um objetivo maior" (fala de um engenheiro).

Nas ações de plantio os técnicos decidem os projetos pela carência de alguns bairros e a procura dos moradores. Geralmente são feitos na época das chuvas e dependendo da disponibilidade de mudas. Porém tudo é feito "sem convergência de ações" (relato de técnico).

Alguns técnicos defendem a necessidade de conscientizar a comunidade através de iniciativas de educação, e acham que essas iniciativas deveriam ser agressivas, "fazer auê", “como usar cinto de segurança, quem não tiver árvore em frente de casa deve se sentir constrangido" avalia um deles.

De acordo com um Relatório de Atividades do Departamento de Ecossistemas para os anos de 1997 a 2000, foi desenvolvido apenas um programa com caráter educativo para o setor, o projeto "Caminhando pela Sombra". O Viveiro Municipal realiza um outro programa educativo voltado à recepção de estudantes em suas instalações. 


\section{- Projeto "Caminhando pela Sombra"}

Entre os anos de 1998 e 1999, a SEDEMA realizou o programa "Caminhando pela Sombra" que tinha como objetivo o plantio de quase 10.000 árvores. Neste programa cada um dos quatro setores levantou um quadrilátero, identificando as espécies e os problemas existentes, quais indivíduos arbóreos poderiam ser retirados e os locais potenciais para plantios de novas árvores. Houve trabalho de educação ambiental nesta etapa, porém na opinião dos técnicos "não foi um trabalho muito agressivo, pois por volta de $50 \%$ dos moradores recusaram o plantio" avalia um deles.

Neste trabalho de convencimento de "porta em porta", uma engenheira agrônoma da prefeitura conversava com o morador, mostrando fotografias de algumas espécies oferecidas e falando sobre os benefícios da arborização . Segundo os técnicos, observout se que na área central, onde houve o plantio concentrado de Sibipirunas, existiu maior resistência dos moradores. Muitos não se deixaram convencer pelos argumentos apresentados devido a "grandes traumas" anteriores. Os motivos mais alegados pelos moradores foram o problema da sujeira e o entupimento de calhas provocados pela queda de folhas. A maioria dos que aceitaram o plantio, escolheram espécies de pequeno porte.

Segundo uma engenheira agrônoma que participou do programa, outros problemas apontados pelos moradores, "dizem respeito à segurança, pois os galhos das árvores podem facilitar a entrada de ladrões através dos muros, e um outro problema associa-se com portões eletrônicos, que são prejudicados com o levantamento de calçadas e muros por raízes".

Foram solicitados ao Departamento de Ecossistemas maiores detalhes sobre este projeto, como número de árvores plantadas e localização, porém estes dados foram perdidos por falhas no sistema. 


\section{- Projeto de substituição de árvores dos Bairros Santa Rosa-Ipês e Balbo:}

Em 1998 foi realizado um programa para retirada e substituição das árvores em calçadas sob fiação nos bairros Santa Rosa-Ipês e Balbo. Somente no Bairro Santa RosaIpês foram sacrificadas em torno de 250 árvores, consideradas impróprias para calçadas sob fiação elétrica, sendo 229 Ipês e o restante divididos entre outras espécies como, Palmeiras, Chapéu-de-sol, Quaresmeiras, Santa-bárbaras, Eucaliptos, Spatódea, Flamboyants, Oitis e até Murtas, Espirradeiras, Resedás, Hibiscos e outras, consideradas apropriadas para plantio debaixo de fiação. Em substituição às árvores retiradas, foram plantadas as seguintes espécies: 46 Quaresmeiras, 45 Resedás, 46 Espirradeiras, 46 Murtas, 43 Flamboyanzinhos e 21 Melolencas (Fonte: SEDEMA).

Este projeto foi bastante criticado por ambientalistas e partidos de esquerda na cidade, provocando reclamações de moradores inconformados com os cortes, conforme pode ser constatado através do artigos publicados na Gazeta Regional (25/11/98) no Apêndice 07 e no Jornal de Piracicaba (25/11/98)- Apêndice 08.

Segundo a CPFL ainda existem cerca de 3.000 a 4.000 árvores sob fiação primária na cidade, e a intenção é substituí-las por espécies de pequeno porte.

\subsubsection{Legislação:}

Em 1990 foi decretada a Lei 3131 (Apêndice 09) disciplinando que a responsabilidade sobre o manejo da arborização urbana é da prefeitura. Em 1996 foi substituída pela Lei 4214/96 (Apêndice 10). Extensa e complexa, impõe dificuldades à interpretação de alguns artigos, dando brechas à diversas interpretações.

"A legislação é falha, não estipula multa/penalidade e não há como obrigar o morador a replantar", analisa um técnico. 
Atualmente, o morador que deseja retirar a árvore de sua calçada, solicita à prefeitura, através de um pedido protocolado; o processo é encaminhado ao setor responsável, que realiza uma vistoria, aprovando ou não a retir ada. O morador assina um termo de responsabilidade, indicando que vai replantar outra árvore no lugar. E aqui reside uma grande polêmica: Embora este documento obrigue o morador a replantar, a lei não estipula penalidade no caso de não haver replantio. Segundo alguns técnicos "criou-se aqui uma brecha que permite o descumprimento da lei, e muitos, talvez a maioria, dos moradores não efetuam o replantio" (fala de um engenheiro).

Porém, esta responsabilidade pelo replantio também é questionada. No Apêndice 11 encontra-se um artigo escrito por um vereador do Partido Verde na cidade, que ao analisar esta lei municipal, afirma que a responsabilidade pelo replantio seria também da prefeitura e não do munícipe.

“A legislação foi como um 'tiro que saiu pela culatra'. Antes, quando não havia legislação, o próprio munícipe cortava sua árvore, praticava podas, etc, mas isso acontecia com uma freqüência muito baixa, pouca gente o fazia. Com a normatização abriu-se um canal para o corte, a prefeitura passou a ter obrigação de cortar. E a decisão de corte pesa sempre sobre os engenheiros. Então o intuito de proteger acabou criando um canal para o corte. Antigamente poucas pessoas praticavam as podas e supressões, agora $100 \%$ da população pode recorrer à prefeitura" (fala de um técnico).

A legislação prevê a cobrança pela remoção de árvores viárias, de acordo com a tabela abaixo:

Árvores até $4 \mathrm{~m}-25 \mathrm{UFIR}^{6}(\mathrm{R} \$ 26,60)$

Árvores de 4 a 6 m - 38 UFIR (R\$ 40,43)

Árvores com mais de $6 \mathrm{~m}-64$ UFIR $(\mathrm{R} \$ 68,10)$

Em casos em que a árvore ofereça risco ao patrimônio público ou particular, ou à segurança da população, a própria prefeitura é responsável pelos custos da supressão.

Questionamos os técnicos se esta cobrança surte efeito no sentido de restringir, de inibir o morador à solicitar o corte, e ouvimos diferentes opiniões, sendo que alguns

\footnotetext{
${ }^{6}$ UFIR (Unidade Fiscal de Referência): Valor no ano de 2000: R\$ 1,0641
} 
acham que a cobrança acaba por barrar um pouco a onda de pedidos de corte. Outros acham que não, pois "quem não gosta da árvore acaba por pagar qualquer valor para livrar-se do problema".

Outro ponto polêmico na legislação municipal paira sobre o conceito de supressão da árvore, realizada por lei somente pela prefeitura.

Por supressão subtende-se a retirada de toda a árvore, inclusive raízes. Porém na prática o que ocorre não é isso. Deixa-se um pedaço do tronco com as raízes ainda sob o solo, ficando ao encargo do morador a retirada desta parte da árvore.

Após muita polêmica criou-se um artigo de lei que obriga a prefeitura a proceder a destoca, ou seja a retirada do toco e das raízes também, e não somente da parte aérea como vem sendo feito.

Porém, na análise de alguns técnicos existem muitos problemas envolvidos:

"quem reforma a calçada, que são confeccionadas dos mais diversos materiais e acabamentos? Quem assume esta responsabilidade? Enquanto esta lei não for normatizada não há como efetuar a destoca".

Enquanto isso a prefeitura protela o cumprimento da lei alegando que o único equipamento que existe para esta função está quebrado. De qualquer maneira, descobrimos que esta máquina apenas corta o tronco rente à calçada, o suficiente para cimentar novamente, deixando ainda as raízes sob o solo, ou seja, favorece a cimentação porém não o replantio.

Por outro lado, a legislação municipal que disciplina as construções prevê o fornecimento do "Habite-se", documento que regulariza as construções na zona urbana, e para conseguí-lo, teoricamente o proprietário do imóvel deveria ter uma árvore plantada no calçamento viário. Porém "interesses econômicos, políticos (proprietários de imobiliárias) mexem com artigos, manipulam, burlando a lei", relata um técnico.

Enquanto isso, algumas cidades como Curitiba/Pr utilizam incentivos fiscais, como a redução no valor do IPTU para moradores que possuam árvores nas calçadas e áreas particulares, porém em Piracicaba este mecanismo tem sido utilizado de maneira contrária, pois a lei estabelece valores maiores de IPTU para quem possui árvore 
plantada em frente ao imóvel, sob a alegação de que os custos de manutenção de ruas e calçadas aumentam (com varrições, podas, etc).

\subsubsection{Viveiro Municipal}

"Até o ano de 1995, o viveiro que fornecia mudas para Piracicaba localizavase em Saltinho, que até então era um distrito do município, mas com a sua emancipação, tomou posse do viveiro. Havia muita dificuldade com a distância e com a qualidade do solo, e Piracicaba acabou ficando 6 anos sem viveiro. Em gestões anteriores a prefeitura priorizou, sob forte pressão política, ao invés do viveiro, a construção do Observatório Astronômico. Após anos de pressão por parte de técnicos do setor, em 1996 a prefeitura finalmente concordou com a construção do viveiro municipal, no bairro de Santa Rita com área de 60.000 metros2."

Relata a engenheira agrônoma que coordena o viveiro municipal.

Hoje, após sua implantação, o viveiro dá suporte aos plantios fornecendo mudas, tutor, borrachinha e a terra preparada para plantio.

$\mathrm{O}$ viveiro trabalha fornecendo mudas também para empresas à base de troca. Segundo a coordenadora, a terra utilizada para a produção de mudas vem da prefeitura e a matéria orgânica é à base de torta de filtro, que também é obtida através de troca com a Usina Costa Pinto.

"No Viveiro realiza-se um trabalho de educação ambiental para trabalhar a conscientização ambiental de crianças" relata uma profissional do viveiro. Todos os dias recebem 2 classes (uma de manhã, outra à tarde) de crianças da rede estadual de ensino. Fornecem cartilha, realizam uma palestra e monitoram a visita das crianças às instalações do viveiro, onde lhes é mostrado todo o processo de produção de mudas. Em 1999 receberam 11.000 crianças. Este trabalho iniciou-se em 96 junto com a Secretaria da Educação do município e a Delegacia de Ensino. 


\section{Produção do Viveiro:}

Fornecem mudas para as seguintes finalidades:

.Arborização Urbana:

- arborização de calçadas

- arborização de praças e jardins

- arborização de áreas verdes

.Arborização de mata ciliar - espécies próprias para margem de rio

Estas mudas são distribuídas à SEDEMA e à população que vai até o viveiro, pois munícipes e empresas procuram o viveiro em busca de mudas de árvores para plantio em calçadas, praças, quintais, chácaras e áreas verdes, e as doações de mudas são feitas com a indicação de espécies para calçadas sob fiação e calçadas sem fiação.

A produção é contabilizada através dos registros de saída de mudas do Viveiro. O quadro 06 mostra qual foi a sua produção e a destinação de mudas do ano desde a sua implantação, no ano de 1996, até o mês de Abril de 2000.

\begin{tabular}{|l|r|r|}
\hline ANO & Arborização Urbana & Mata Ciliar \\
\hline 1996 & 435 & 10.565 \\
\hline 1997 & 1.809 & 2.646 \\
\hline 1998 & 7.248 & 317.554 \\
\hline 1999 & $(*) 22.906$ & 94.896 \\
\hline $2000^{*}$ & 3.827 & 50.835 \\
\hline Total & $\mathbf{3 6 . 2 2 5}$ & $\mathbf{4 7 6 . 4 9 6}$ \\
\hline
\end{tabular}

Fonte: Viveiro Municipal de Piracicaba - Junho/2000 (*) Até Abril.

(*) Não foi possível identificar a destinação destas mudas. Possivelmente alguma parte deste número tenha sido destinada ao projeto "Caminhando pela Sombra"

Quadro 6 - No. de mudas distribuídas pelo Viveiro Municipal de Piracicaba de 1996 até Abril/2000.

No Anexo 04 está uma relação das espécies produzidas no viveiro e colocadas à disposição para a SEDEMA. 


\subsubsection{A atuação do Pelotão Ambiental}

O Pelotão Ambiental, faz parte do quadro da Guarda Civil, funcionando como um "braço" da SEDEMA. Atuam no controle ambiental, fiscalizando poluição sonora e visual, lixo, animais soltos, depredações ao patrimônio público etc. Sua função quanto à arborização urbana é a de coibir ou evitar poda, supressão, poda drástica, anelamento e outras formas de agressão às árvores viárias. O instrumento utilizado para isso é a multa.

Valor monetário das multas:

Poda - 49 UFIR $^{7}$ (R\$ 52,14)

Supressão - 98 UFIR (R\$ 104,28)

Danificação/Anelamento - 250 UFIR (R\$ 266,02)

Após o recebimento da notificação o morador tem 30 dias para entrar com recurso.

Quando fazem a vistoria para notificação, quase sempre recebem a desculpa do morador sobre desconhecimento da lei.

Segundo o funcionário do PA entrevistado, a maioria das alegações apresentadas pelos moradores fala da aglomeração de pessoas e carros à sombra das árvores, da quebra de calçadas e do entupimento de calhas.

No caso das denúncias sobre danos, encontram dificuldades relacionadas à falta de provas que apontem o morador como responsável pelo dano. Geralmente algum vizinho faz a denúncia sobre anelamentos, podas drásticas, supressões, etc., mas não há ninguém para testemunhar. Existe, também o caso de árvores mortas por envenenamento onde o P.A. não tem como detectar que tipo de substância foi administrada à árvore, pois não têm como realizar análises.

As denúncias de supressão e anelamento em sua maior parte, geralmente são feitas por vizinhos. O técnico responsável pelo setor fiscaliza e solicita o replantio. O Pelotão Ambiental faz a notificação. Se o morador repuser não é multado.

\footnotetext{
${ }^{7}$ UFIR (Unidade Fiscal de Referência): Valor no ano de 2000: R\$ 1,0641
} 
Segundo funcionários do Pelotão, normalmente ocorrem poucas notificações. A multa acaba acontecendo somente em casos de poda, supressão e danificação. A lei não prevê penalidade no caso de o morador não replantar.

“O morador assina um documento se responsabilizando pelo replantio, mas não há como obriga-lo a replantar, pois a lei não é muito precisa, dá brechas na interpretação", relata o funcionário do PA.

Fazem a recomendação de replantio ou a notificação, mas não possuem nenhum treinamento para esta orientação em termos técnicos, encontrando dificuldades para a recomendação de espécies.

O trabalho do Pelotão Ambiental pareceu bastante isolado, sem articulação com os demais setores que administram a arborização da cidade.

\subsubsection{Questão cultural}

Reproduzo, a seguir, um trecho de uma entrevista realizada com o engenheiro especialista em arborização urbana, e que pela natureza de sua atividade atual, conhece grande números de municípios do estado de São Paulo e sua arborização.

Engenheiro: (...) Porque é assim, se perguntar... no estado todo...em qualquer cidade, pra qualquer pessoa, se ela gosta de árvore, ela gosta de árvore enquanto ela tá tendo benefício... na hora que vem os inconvenientes, ela não quer saber de árvore, ela quer tirar... né? Então, é uma situação generalizada. Agora em Piracicaba, é muito forte isso. Muito forte porque a cidade, tem uma árvore assim predominante... não sei se ainda predomina, mas predominou, Sibipiruna, que é uma árvore espetacular, sabe? Que virou bode expiatório nessa cidade aqui. Então porque que ela virou? Porque ela foi mal escolhida pros locais onde ela foi plantada, introduzida. Então, a árvore ideal não existe, todo mundo sabe disso, a gente sabe, né? todo mundo quer a árvore ideal, mas a árvore ideal não existe. Não tem, então você vai escolher, a partir de determinados parâmetros que você deseja que sejam atendidos. Mas assim, árvore nota 10 não existe. Existe árvore nota 7... dez não existe.

Pesquisadora: Agora essa questão do cimento, da calçada, do asfalto chegar até o colo da árvore... é uma coisa assim... eu sou do Paraná e eu nunca vi isso. Fui ver isso aqui em Piracicaba, e morei em Botucatu também, nunca tinha visto isso lá. E é 
uma coisa cultural isso, o piracicabano que não gosta de terra, que tem horror à terra, não pode ver um centímetro de terra? Você vê isso em outras cidades?

Engenheiro: Não. É aqui que a gente vê com maior intensidade. Tem cidade do estado de São Paulo, Ilza, que se você for mexer com uma árvore o cidadão briga com você... a região de Ribeirão Preto aí... como é que chama aí, perto de Jardinópolis... nós fomos dar um curso de poda lá, o pessoal não deixava mexer nas árvores não... São Joaquim da Barra chama...

A relação do homem é muito forte. Existe uma relação de amizade... é muito grande... todo mundo tem uma árvore na sua vida. Pode ver... você pode até achar estranho eu estar falando isso, mas todo mundo tem uma árvore na sua vida .... ou é uma lembrança boa ou é uma lembrança ruim. Normalmente é uma lembrança boa. Mesmo que seja uma frutífera ou coisa assim... desde criança. Todo mundo tem uma árvore na lembrança. Ou a árvore que admira...

Este relato nos mostra que existem diferentes percepções sobre as árvores entre as pessoas, e isto pode variar de região para região, de cidade para cidade, e mesmo dentro de uma mesma cidade, dependendo do contexto sócio-cultural dos moradores de determinado bairro. Estas percepções podem variar também de acordo com as experiências com árvores vividas desde a infância

No caso de Piracicaba parece evidente que uma parcela da população possui hábitos e comportamentos bastante arraigados, no sentido de buscar eliminar o que consideram "sujeira" provocada pelo acúmulo de folhas e flores de árvores além de restringir os espaços de terra ou cobertura verde em suas áreas particulares ou calçamentos frontais.

Estes hábitos e comportamentos são culturais, e poderão modificar-se com o tempo, de acordo com os valores adquiridos pelas novas gerações de indivíduos que ocuparão este espaço urbano. Preencher estas gerações - e mesmo substituir os antigos , entre as gerações que agora o ocupam - com e por valores mais solidários, tolerantes e afetivos para com as árvores, por valores menos individualistas e mais cooperativos, onde o esforço e o sacrifício individuais resultam na satisfação do interesse coletivo, é uma das "chaves" a serem utilizadas em projetos e campanhas educativas. 


\subsubsection{Repercussão nos jornais e pressão popular}

Na mídia, freqüentemente o assunto ganha destaque em primeira página, com inúmeras denúncias realizadas pelos próprios moradores da cidade e por ambientalistas. Aos jornais os técnicos alegam quase sempre, a necessidade do corte devido a problemas fitossanitários, porém as solicitações dos moradores que desejam o corte, baseiam-se muitas vezes em problemas como entupimento de calhas ou na "sujeira" provocada pelas folhas que caem em determinada época do ano.

Segundo os técnicos a pressão dos ambientalistas concentra-se sobre acontecimentos isolados, como corte de alguma árvore mais antiga ou conjunto de poucas árvores isoladas numa praça por exe mplo.

"as sibipirunas da cidade estão sendo devastadas, mas isso eles parecem não enxergar, preferem brigar por causas isoladas e já perdidas. A maioria dos casos de corte de árvores antigas, dessas que chamam a atenção da imprensa e dos ambientalistas, já passaram por vistoria e comprovação técnica da necessidade de corte" (fala de uma engenheira).

Denúncias sobre anelamentos criminosos (JP-28/01/2000, apêndice 12), cortes clandestinos tratados como crimes ambientais (JP-02/04/2000, apêndice 13), reclamações de moradores que condenam a retirada de árvores por conceitos estéticos alegados pela prefeitura (Tribuna- 19/07/97, apêndice 14), protestos contra corte de árvore antiga (JP-22/07/98, apêndice 15), irritação de moradores com corte maciço de árvores (JP, apêndice 16) e a avaliação do político militante do Partido Verde na cidade: "Falta verde na vida dos piracicabanos" (JP - 01/08/97, apêndice 17) são constantes e corriqueiras nos jornais.

Eu mesma, como agrônoma e moradora da cidade me senti na obrigação de manifestar-me chegando a utilizar o Jornal de Piracicaba (edição de 19/10/2000) e a TV local na mesma data para expressar minha opinião a respeito de um corte "em massa" praticado pela prefeitura nas calçadas frontal e lateral do Lar Betel, que abriga idosos. Alguns meses depois foi efetuado o replantio com as espécies Canelinha e Ipê. 
Estes são apenas alguns exemplos da insatisfação de uma parcela da população, que encontra nos meios de comunicação um canal para expressar sua indignação perante os cortes sucessivos que ocorrem na cidade.

No artigo entitulado "A resposta da natureza" (JP - 07/09/98 - Apêndice 18), encontramos o desabafo de um leitor, aparentemente morador antigo da cidade, que de maneira poética e afetiva retrata o sofrimento de um ipê, condenado à uma morte lenta devido a um artifício que procura burlar a lei que impede a derrubada de árvores naquele local. Um desfecho surpreendente e comovente finaliza o artigo, com a resposta da natureza expressando-se num belo florescer do ipê amarelo, "que cumpre seu destino de florescer na primavera".

\subsubsection{Exemplos externos}

No ano de 2000 a ESALQ realizou um seminário sobre arborização urbana ${ }^{8}$. Relataremos aqui algumas experiências transmitidas através de palestras proferidas por profissionais vindos de outras cidades e regiões do país. Pelos relatos feitos, são exemplos de políticas comprometidas com o verde urbano, amparadas em posturas responsáveis, arrojadas e corajosas por parte das equipes técnicas encarregadas de implantá-las. Tampouco se estabeleceram de uma hora para outra, mas foram construídas ao longo de muitos anos, enfrentando dificuldades das mais diversas naturezas.

De acordo com uma profissional da Prefeitura Municipal de Maringá/Pr, a cidade apresenta uma população de 300.000 pessoas, possuindo $28 \mathrm{~m} 2 / \mathrm{hab}$ de área verde. Existem 80.000 árvores em suas vias públicas, numa relação de 1 árvore para cada 4 habitantes. Lá também predominam as Sibipirunas, seguidas pelas Tipuanas, pelos Jacarandás e pelos Ipês. "A qualidade da arborização urbana está muito mais

\footnotetext{
${ }^{8}$ Seminário sobre Arborização Urbana: das Necessidades Técnicas à Educação Ambiental, data: 27-28/09/2000 - ESALQ/USP-Piracicaba/SP.
} 
dependente da decisão política e de planejamento e apoio da sociedade do que de aspectos técnicos" foi uma de suas considerações iniciais. Maringá possui uma legislação que define critérios básicos para a arborização, e segundo com esta profissional, é rigorosamente cumprida pelos munícipes e pelas autoridades.

Falando sobre a convivência de uma arborização de grande porte com a fiação elétrica, ela contou que muitas experiências foram feitas. "A chamada poda em ' $V$ ' é uma solução apenas parcial, pois desequilibra a árvore e o resultado pode ser muito mais danoso", e assim outras soluções foram buscadas.

O que ainda é uma experiência para muitas cidades, Piracicaba entre estas, em Maringá já é uma solução consumada. A implantação da "rede compacta protegida" foi realizada no decorrer de 6 anos, e hoje toda a cidade conta com este recurso para proteger a fiação elétrica dos danos causados pelos galhos de árvores que a alcançam. Já não existe problemas com desligamento de energia na cidade. Dentro deste sistema, os cabos elétricos são recapeados com um material que os protege dos atritos e separados por um condutor de fios colocado espaçadamente. Isto permite a convivência entre árvores de grande porte e a fiação elétrica.

Este projeto foi implantado com recursos da prefeitura municipal e da Copel (Companhia de Eletrecidade do Paraná), na proporção de 50/50, sendo compensado pela considerável redução no número de podas realizadas e pela diminuição da manutenção de cabos elétricos.

Outro recurso utilizado de maneira exemplar é o rebaixamento da iluminação pública, que consiste na colocação de globos de iluminação abaixo das copas das árvores. Esta solução foi sugerida pela própria comunidade, a partir de uma associação de bairro, onde os moradores reclamavam da escuridão provocada pelas árvores à noite. Esta solução demonstrou-se totalmente viável e satisfatória e está sendo estendida os outros bairros da cidade.

A cidade de Porto Alegre/RS se destaca por possuir uma equipe técnica muito preparada e unida, capaz de fazer frente à pressões de políticos e à mudanças de gestões. Isto é possível graças ao apoio da população, que defende sua arborização, e que chegou neste nível de conscientização devido ao esforço daquela equipe em administrar esta 
arborização corretamente e utilizando-se de programas educativos eficientes. De acordo com sua representante, a Secretaria Municipal do Meio Ambiente de Porto Alegre instituiu um grupo interdisciplinar para elaborar e orientar a implantação da arborização urbana.

Segundo ela, existe o acompanhamento técnico para o lançamento de postes em ruas arborizadas, impondo limites mínimos de distribuição do poste à árvore, dependendo de seu porte.

A intenção em relatar estas experiências é a de mostrar que é possível superar obstáculos considerados por muitos técnicos como insuperáveis, é possível arrojar, ser original, deixar velhas idéias e maneiras de fazer para trás, abrindo espaço para o novo, pois durante a pesquisa ficou muito claro para mim que o preconceito popular contra as árvores é uma questão cultural que pode ser modificada com o tempo, mas que sobretudo a atitude dos técnicos responsáveis pelo seu planejamento e execução é que define o futuro e a qualidade da arborização de uma cidade.

É claro que muitas questões devem ser consideradas aqui, como diferenças regionais de clima, solos, cultura, técnicas e políticas, etc, que podem ou não favorecer a implantação de políticas mais comprometidas com o verde urbano, porém esta não deve se constituir em uma eterna desculpa, como muitas vezes ouvi durante esta pesquisa, para não se fazer diferente do que vem sendo feito.

Copiar pura e simplesmente não é recomendável, nem realizável muitas vezes, mas orientar-se pelo exemplo externo pode se constituir em fonte de ricas e inovadoras idéias.

"Hoje o verde não deve ser mais obediente ao traçado da cidade, mas estruturador do desenho da cidade, pois é ele que vai criar uma novo micro-clima no ambiente urbano".

Esta foi a fala de uma especialista em planejamento urbanístico, apontando para um futuro onde idéias inovadoras e ousadas substituirão na prática atuais conceitos limitados e limitantes que ainda prevalecem nas nossas cidades. 


\subsubsection{Conclusões da Fase 1}

Partindo dos objetivos iniciais de compreender a situação atual da arborização viária de Piracicaba, identificando alguns fatores condicionantes, opiniões e maneiras de pensar dos profissionais envolvidos em seu planejamento e administração, podemos tecer algumas conclusões baseados nos resultados da pesquisa:

- A inexistência de um inventário ou de informações sistematizadas ao longo do tempo dificulta o levantamento de seu histórico e diagnóstico mais detalhado;

- O índice oficial de área verde de apenas 3,6 m2/hab é indicativo de uma arborização pobre em termos comparativos;

- A arborização da cidade não foi implementada de maneira planejada;

- O estudo identificou apenas dois projetos de plantio - "Caminhando na Sombra" e "Substituição de árvores sob fiação nos bairros Balbo e Santa Rosa-Ipês", ocorridos nos últimos anos;

- Árvores de grande porte estão sendo suprimidas sistematicamente das ruas, sendo substituídas em sua maioria por espécies de pequeno e médio portes;

- Uma tese de doutorado e outras fontes de evidência sinalizam que o estado fitossanitário de uma grande parte das árvores existentes está comprometido por falhas de implantação e manejo anteriores e que estes erros parecem se repetir (podas, covas de plantio com dimensões insuficientes, espaço insuficie nte para a planta no calçamento viário, etc);

- Os critérios técnicos adotados pela SEDEMA para autorizar os cortes são questionáveis e necessitam ser reavaliados e modificados;

- Existem indícios de que políticos da cidade utilizam-se da conquista de autorizações para corte de árvores como meio para captação de votos;

- Os setores encarregados de seu planejamento e administração parecem funcionar de forma desarticulada (entre si e entre os demais setores responsáveis pelo 
planejamento urbanístico da cidade), não havendo consenso entre os técnicos sobre questões fundamentais;

- Com exceção do programa de educação ambiental voltado para crianças realizado pelo Viveiro Municipal, não foram identificados projetos de educação ambiental que visem a conscientização da população sobre a importância das árvores;

- A legislação do município não é clara em alguns pontos fundamentais, dando margem a diferentes interpretações, e isso tem possibilitado que a população elimine árvores viárias sem o devido replantio;

- Os técnicos que trabalham no setor não dispõem de uma formação filosófica a respeito do tema, o que os ajudaria a enxergar a questão e atuar sobre ela de forma não apenas técnica, porém mais afetiva e comprometida com a "árvore";

- Existem poucos trabalhos científicos realizados por pesquisadores das universidades presentes na cidade. A participação destas universidades nos assuntos relativos à arborização urbana na cidade poderia ser mais ativa se houvesse maior articulação entre a Prefeitura Municipal de Pracicaba e estas universidades;

- A inexistência de uma política pública definida e clara, demonstra que ainda falta planejamento para o setor, que é negligenciado pela esfera política, caminhando ao sabor das mudanças de gestão e das pressões impostas pela CPFL;

Milano (1994) traça alguns requisitos básicos para a existência de uma adequada arborização nas cidades, são eles:

A) reconhecimento institucional da importância da arborização através de ações e políticas claramente definidas;

B) criatividade técnica e política das soluções propostas no planejamento através de abrangente e claro diagnóstico das características urbanas;

C) decisão política da administração pública e conseqüente capacidade técnica na implantação das mesmas; 
D) apoio da sociedade urbana, que pode depender de programas específicos de conscientização;

E) monitoramento do conjunto de procedimentos e ações efetuadas, bem como dos resultados alcançados, para as correções que se fizerem necessárias, considerando o caráter dinâmico do planejamento. (Milano, 1994)

As conclusões apresentadas acima e a forte impressão de que estes pré-requisitos traçados por Milano (1994) não estão sendo atendidos em Piracicaba, nos levam a projetar um quadro pessimista para o futuro. No último capítulo desta dissertação pretendo apresentar algumas sugestões com a finalidade de contribuir para a melhoria deste quadro.

Após o período de pesquisa, que abrangeu os anos de 1999 e 2000, com a mudança de gestão política (o PT assumiu a prefeitura em Janeiro de 2001), algumas modificações aconteceram. Em fevereiro de 2001 o CONDEMA (Conselho de Defesa do Meio Ambiente) determinou a paralisação dos cortes de árvores, que foram retomados vinte dias após, com um limite fixado em 40 pedidos de corte por mês a serem atendidos, ou seja 2 pedidos de corte/dia. Segundo a SEDEMA a média para cada pedido é de 1,2 árvores, então temos aproximadamente 48 árvores cortadas a cada mês, resultando em 576 árvores em 1 ano, o que ainda é um número considerável de árvores eliminadas das ruas. Porém se houver o replantio com espécies adequadas e de porte significativo, estes cortes poderão ser compensados.

Para que se conseguisse essa redução, os critérios utilizados nos laudos técnicos foram reavaliados, permanecendo somente os critérios "comprometimento do estado fitossanitário da árvore" e "abalos na estrutura do imóvel provocados pelas raízes da árvore".

Nossa opinião é de que este tipo de decisão, embora bem intencionado, tem caráter frágil e precário, pois se não for provisória revelar-se-á inócua. Ou seja, o que realmente precisa ser feito, em curto período de tempo, é gestar-se uma verdadeira política pública de arborização urbana para o município. 


\subsection{Resultados e discussão da Fase 2}

\subsection{1 "Oficina de futuro"}

Os grupos pesquisados demonstraram grande receptividade a este tipo de dinâmica, pois pelo que pude perceber, difere um pouco da estrutura de reunião a que estão acostumados. Possibilitou-lhes uma presença mais ativa nas reuniões, principalmente para o grupo de jovens.

Todas as respostas e resultados estão relacionados integralmente no apêndice 19.

Grupo de jovens - 24 participantes - idades: entre 13 e 27 anos.

Grupo de terceira idade: (07 participantes - idades: entre 40 de 72 anos)

- “Árvore da Esperança”

\section{Pergunta 1: “Como você gostaria que fosse a rua/bairro em que mora?"}

\section{Respostas do grupo de jovens:}

- A preocupação com as árvores está presente em 11 de 24 respostas, com $48 \%$ de frequiência. As respostas apontam o desejo de que haja "mais árvores" no bairro ou rua e de serem "mais bem cuidadas".

\section{Respostas do grupo $3^{\mathrm{a}}$ idade:}

- A preocupação com as árvores está presente em 3 de 07 respostas, com 42,8\% de frequiência. Apontam também o desejo de que haja "mais árvores" no bairro ou rua e de serem melhor cuidadas ou manejadas. Neste grupo houve muitas respostas do tipo subjetivas como o desejo de "União", "Participação", "Conscientização", etc. 
Juntando os resultados nos dois grupos temos os seguintes itens citados com maior freqüência (número de respostas num total de 31):

\section{"Como você gostaria que fosse a rua/bairro em que mora?"}

- Com menos Lixo: 16.

- Com mais e/ou melhor Arborização: 14

- Com mais Segurança: 12

- Com maior Conservação de ruas/calçadas: 11

- Com menos Poluição (ar, água, sonora, visual): 11

- Com mais Lazer/recreação: 06.

As respostas nos dois grupos pesquisados demonstram um grau elevado de preocupação com a arborização da rua ou bairro. Este resultado leva a concluir que apesar do "suposto" preconceito contra árvores, esta amostra de moradores preocupa-se ou sente falta de uma arborização mais abundante e de qualidade.

É conveniente comentar aqui que o tema da reunião (arborização), não era revelado até a próxima pergunta, pois poderia-se influenciar/induzir respostas entre os integrantes dos grupos.

Pergunta 2: Como você gostaria que fosse a arborização de sua rua/bairro? (desenhe ou descreva)

\section{Respostas grupo de jovens:}

- Com exceção de duas pessoas que não responderam, todas as demais respostas apontam o desejo "mais árvores", "muitas árvores", "repleta de árvores", "muito arborizada", "quase uma floresta","1 casa 1 árvore", "arborização densa",etc

- 06 respostas apontam para o desejo de haver árvores frutíferas

- 06 respostas apontam para o desejo de haver árvores com flores.

“a gente taba comentando.... falta praças com árvores.... no nosso bairro não tem nada!..." (fala de uma jovem do grupo). 


\section{Respostas do grupo $3^{\mathrm{a}}$ idade:}

- 02 pessoas manifestam estar contentes com a arborização de sua rua, 05 manifestam o desejo de haver mais árvores

- 03 pessoas desejariam que houvesse árvores frutíferas

- 03 pessoas desejariam que houvesse mais árvores com flores.

Portanto, através das respostas às duas perguntas formuladas na "Árvore da Esperança" seria possível concluir que na "rua ou bairro dos sonhos" dessas pessoas existem mais, muitas árvores; algumas "sonham" com árvores frutíferas, outras com árvores que floresçam.

\section{- "Muro das Lamentações"}

Pergunta 3: Quais são os problemas que as árvores trazem aos moradores em sua rua?

\begin{tabular}{|l|c|c|c|}
\hline Problemas & Grupo jovens & Grupo 3 idade & total \\
\hline Danos à calçada & 18 & 03 & 21 \\
\hline Sujeira & 16 & 02 & 18 \\
\hline Danos à rede elétrica & 14 & - & 14 \\
\hline Entupimento de calhas & 11 & 02 & 13 \\
\hline Provoca brigas de vizinhos & 04 & - & 04 \\
\hline Abala estruturas de casas & 02 & 01 & 03 \\
\hline Atrai pássaro/morcego/In & 03 & 01 & 04 \\
\hline Queda sobre carros/casas & - & 01 & 01 \\
\hline Entupimento de bueiro & 02 & - & 01 \\
\hline
\end{tabular}

Quadro 7 - Problemas que as árvores trazem aos moradores das cidades - "Muro das Lamentações"

Este quadro demonstra ou confirma que os problemas mais representativos para esses moradores são: danos à calçadas, sujeira, danos à rede elétrica e entupimento de calhas, apontados com maior freqüência neste "muro de lamentações" sobre as árvores. 
Nota-se que problemas mais graves ou tecnicamente mais comprometedores, como "quedas sobre carros e casas" ou "abalo de estruturas das casas" são citados em número bem menor de respostas, sendo portanto, menos percebidos ou importantes na opinião desses moradores.

Após a afixação e observação das fichas com os problemas que as árvores trazem aos moradores da cidade no "muro das lamentações", discutíamos sobre estes problemas, explorando possíveis alternativas e formas de enxergá-los. Nos dois grupos manifestour se uma disposição muito grande em reconsiderar as questões ou problemas levantados, sendo apontados inúmeras possíveis soluções que não implicariam no sacrifício da árvore.

"sabe o que o meu pai fazia com as folhas? Ele pegava as folhas e, todos os dias, num saco pegava e levava pra horta que tinha no fundo do quintal e usava como esterco...", lembra um integrante do grupo de jovens.

\section{- "História do Pedaço"}

História elaborada a partir das entrevistas realizadas pelos jovens:

\section{“a história das árvores do bairro:”}

Antigamente, havia poucas casas e poucas árvores no bairro. À medida que as casas foram sendo construídas, os próprios moradores foram plantando suas árvores.

Mas...

.naquela época as casas eram simples, não tinham garagem, pois existiam poucos carros.

a necessidade de se construir garagens e reformar as casas fez com que os moradores cortassem suas árvores, que estavam mal localizadas

Porque não plantaram outras no lugar??

Porque...

. as árvores que existiam antes trouxeram problemas:

entupiam calhas com suas folhagens, quebraram calçadas, 
comprometeram alicerces das construções, danificaram a rede elétrica, Além disso, outras árvores que não foram arrancadas por causa das reformas foram sendo cortadas porque secaram, ficaram muito velhas, cheias de "bichos" Hoje, para cortá-las os moradores precisam ter licença da prefeitura e são obrigados a replantar outra no local. Porém, só quando há denúncia”.

Esta história nos faz imaginar que a construção do bairro em questão foi realizada com bases em moldes antigos, onde não se previa o aumento do número de automóveis e nem a presença de arborização nas calçadas, pois pelo relato dos moradores, as árvores foram compondo a paisagem do bairro aos poucos, trazidas pelos próprios moradores. É de se imaginar que esses moradores não tiveram acesso a orientação técnica adequada sobre a escolha de espécies e sobre o local mais apropriado para plantio. Uma visita àquele bairro mostrou que ali predomina, onde existe arborização viária, a Sibipiruna. Em alguns locais pode-se observar também alguns exemplares de Pautbrasil e Chapéutde-Sol, alguns totalmente secos, talvez por "anelamento" ou injeção de alguma substância tóxica.

Os problemas alegados para o corte das árvores são alguns daqueles já mostrados no "muro das lamentações", acrescidos da necessidade de retirá-las para dar lugar a reformas e construção de garagens. Os moradores parecem "traumatizados" com os problemas causados pelas antigas árvores, e não dispostos a replantar com outras espécies. A visita ao bairro permite verificar que em muitas residências foi feito o replantio com espécies de pequeno e médio porte (Espirradeiras, Murtas, Hibiscos, Flamboyant-mirim, Quaresmeiras, etc.). A história revela também que alguns moradores enxergam a Prefeitura ou o órgão que a representa como punitiva e autoritária, o que os coloca numa posição submissa e passiva em relação a este espaço coletivo que é o seu bairro, a sua rua.

Na sequiência, fotos da época de infância trazidas por um dos integrantes do grupo, hoje com 27 anos de idade, mostrando árvores que existiam em sua rua e a brincadeira de "subir em árvores" 


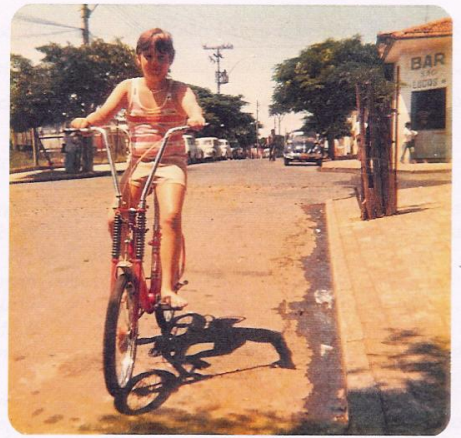

Figura 10 - Foto antiga trazida por um integrante do grupo de jovens.

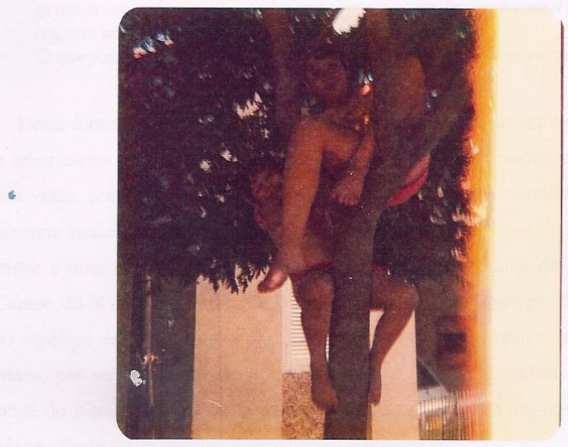

Figura 11 - "Subindo em árvores, quando elas existiam". Foto de infầncia de um integrante do grupo de jovens, hoje com 27 anos. 
No grupo de terceira idade não houve a construção da "história do pedaço", porém no decorrer da segunda reunião houve um momento para discussão sobre a arborização da cidade no passado, com várias lembranças trazidas pelos participantes.

A seguir transcrevo um trecho da conversa:

- "Você sabe lá perto do cemitério? Não tem o estádio lá de futebol? Você sabe o que era lá? Um lindo bosque... Nós dávamos a mão dez crianças pra abraçar uma árvore lá. Cadê? Cortou tudo!...

- Só tem agora aquela uma da esquina...

- Só aquela da esquina... a castanheira... é a única que sobrou!...Era um bosque lindo, lindo, lindo!...

- Já faz uns 50 anos que acabaram com aquilo, pra fazer o estádio de futebol. Acabou.

- Que lembranças mais vocês têm?...

- A cidade, em 50 anos, ela ficou umas quatro ou cinco vezes maior... era tudo mato... nas ruas, as calçadas era tudo terra, ou tijolo... tinha árvores por todos os quintais.

- E que tipo de árvores tinha?

- Eu acho que era mais nativa...Eu lembro do bosque, tinha "Jambo", tinha aquela "garrafinha preta", tinha essa "castanheira"...abria, caia castanha, a gente criança ia pegar... tinha eucalipto...eu lembro por causa das frutas, porque a gente ia pegar, né?

o que faltou aqui foi isso. Foi deixarem bosques, foi deixarem praças...”

Desta forma eles remexeram em suas lembranças de como era a cidade antigamente, da arborização existente... Exaltam a arborização que antigamente existia na cidade e em suas vidas, preenchendo suas infâncias, seus quintais e seus caminhos. No trecho em que uma senhora se refere a uma "castanheira", observa-se que na realidade a referida árvore é uma Sapucaia, antiga e frondosa, situada na esquina do estádio de futebol (Campo do XV de Novembro de Piracicaba). Este é um exemplo do desconhecimento das espécies existente entre a população, pois esta árvore é realmente uma referência na cidade, por ser antiga, de um porte majestoso e de imensa beleza. Todos os anos, na época do Natal ela é enfeitada com luzes pela prefeitura, e um dos cartões postais da cidade. Ainda assim, muitos desconhecem sua espécie...

Um outro fato significativo que pode ser extraído deste relato é a substituição de um bosque inteiro de árvores de importância histórica, cultural, ambiental e social para a 
cidade, que se constituía numa das poucas áreas verdes abertas ao público aqui existentes, por um estádio de futebol destinado a um público restrito que paga para ali entrar. Este tipo de priorização é um exemplo de como as administrações públicas anteriores têm encarado a questão das áreas verdes na cidade.

Uma das participantes trouxe fotografias de um terreno pertencente à prefeitura que existe em frente à sua casa. Essas fotos retratam a história de construção desse espaço, de um terreno baldio a uma linda área verde, com Flamboyants, Ipês, Chuvas-de-ouro, Azaléias, etc.. Há uma foto de seu filho, ainda pequeno, brincando nesse terreno baldio (figura 12), e na seqüência uma outra foto dele já adulto, com seu próprio filho no colo em meio às frondosas e coloridas árvores por eles plantadas e cuidadas (Figura 13). 


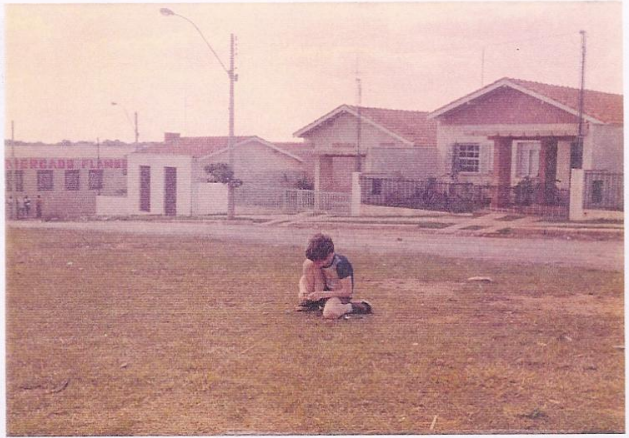

Figura 12 - Filho de uma integrante do grupo de terceira idade brincando num terreno baldio em frente à sua casa.

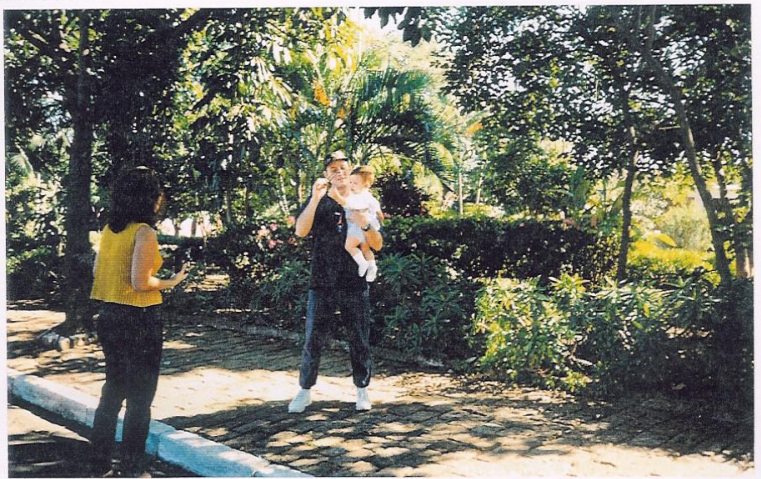

Figura 13 - Em meio à frondosas e floridas árvores, o filho com o neto. Os próprios moradores construíram este espaço. 


\subsubsection{Percepção Ambiental/Fotografias/Expressão Artística}

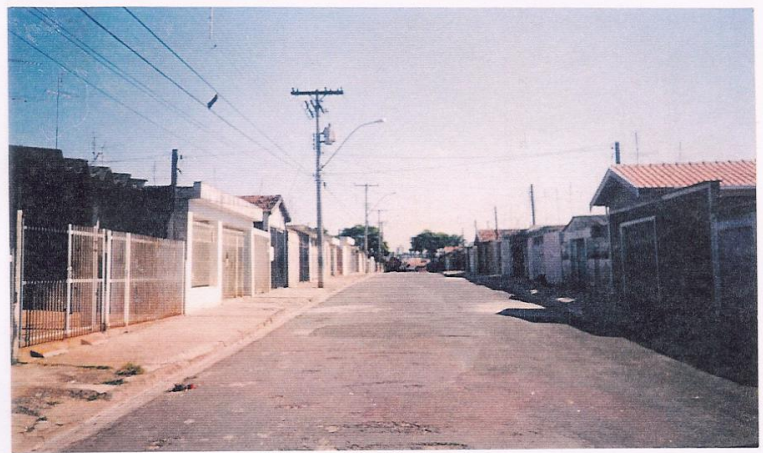

Figura 14 - Fotografia tirada por integrante do grupo de jovens retratando cenários do seu bairro.

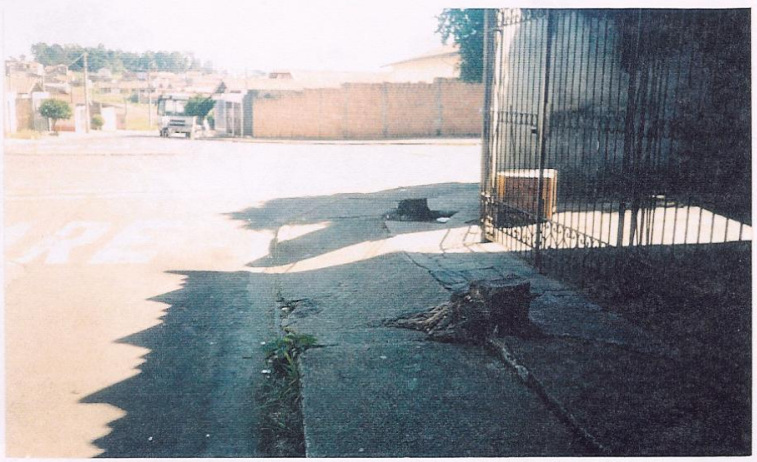

Figura 15 - Fotografia tirada por integrante do grupo de jovens retratando cenários do seu bairro. 


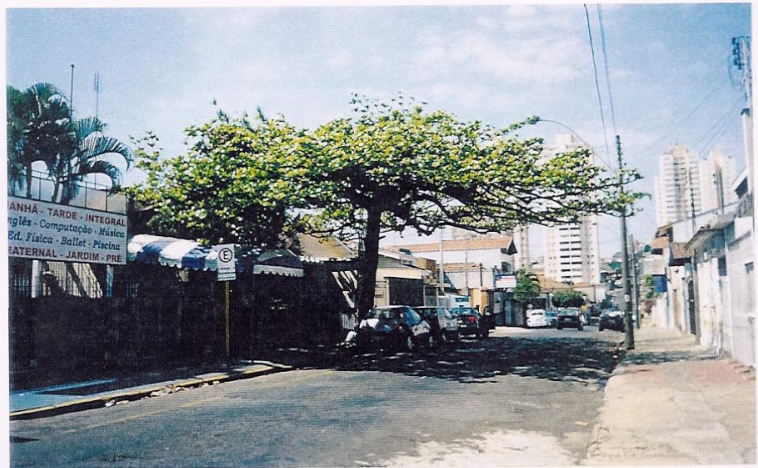

Figura 16 - Fotografia tirada por integrante do grupo de terceira idade retratando cenários da cidade.

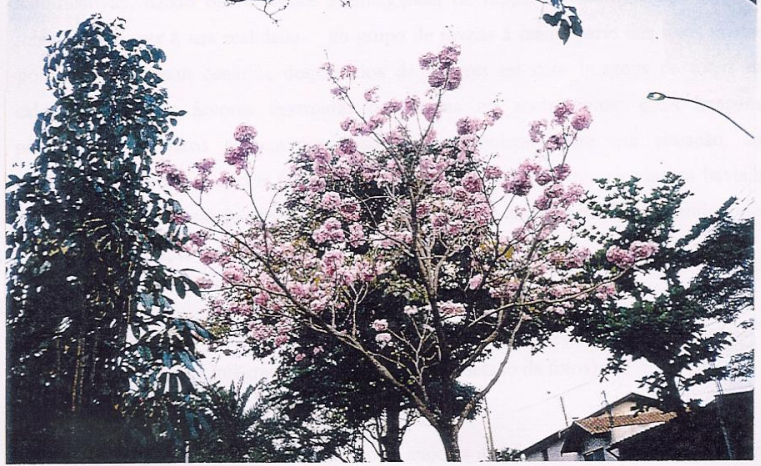

Figura 17 - Fotografia tirada por integrante do grupo de terceira idade retratando cenários da cidade. 
É possível perceber através das fotografias 14 e 15, tiradas por integrantes do grupo de jovens, que os cenários que compõem o seu bairro se caracterizam pela pouca presença de árvores, com as fachadas das casas expostas, as calçadas nuas ou com presença de restos do que foi uma árvore.

Já as fotos 16 e 17, tiradas por integrantes do grupo de terceira idade retratam uma relação bem mais intensa e positiva com as árvores. A foto 16 mostra um Chapéude-sol em frente à casa de um dos integrantes do grupo. Ele orgulha-se de que ela é uma das únicas árvores de grande porte de sua rua. Plantada e cuidada por ele, é defendida com "unhas e dentes" contra os "ataques" de quem deseja o seu corte devido à grande quantidade de folhas que caem em determinado período do ano, provocando "sujeira" na rua.

A foto 17 mostra um cenário com abundância de árvores.

As sessões de exposição de fotos realizada nos dois grupos foram bastante significativas, dando oportunidade à emergência de reações e sentimentos de seus integrantes frente à sua realidade: no grupo de jovens a maior parte das fotos tiradas por eles mostravam cenários desprovidos de árvores ou com imagens de tocos na calçada, ou ainda árvores destruídas por podas ou anelamentos; estas imagens provocaram inúmeros comentários desolados e irônicos sobre sua situação, ao reconhecer nas fotos cenários familiares e conhecidos. Percebo que eles nunca haviam realizado esse exercício de observação sobre seu bairro e que de certa forma sentiram-se tocados pela situação exposta.

"Olha!... essa rua é aquela perto de casa. Nossa, não tem uma árvore mesmo!..." (comentário de um integrante do grupo durante a sessão de fotos).

No grupo de $3^{\mathrm{a}}$ idade, ao contrário, a maioria das fotos tiradas foram mostradas com orgulho, pois retratam situações positivas, com ruas bem arborizadas, árvores de grande porte bem cuidadas, rendendo muitos comentários e histórias durante a sessão. 
"Olha este pé de laranjeira que tem plantado na minha rua!... Ele dá uma laranja doce, doce, que todo mundo adora. Pena que o vizinho acabou com metade dela (podando-a) para que ela não escondesse sua placa. Ele é um cabeleireiro"

“Este é o meu Chapéu-de-sol. Olha só que beleza! É a única árvore da rua. Já me pediram para cortar, mas nem morto eu faço isso!..."

(Comentários de integrantes deste grupo durante a sessão de fotos).

\section{Expressão Artística}

Composição musical feita por integrantes do Grupo de Jovens e apresentada pela

"banda" existente no grupo, sob a forma de Rock, com guitarra, bateria, violão e voz:

\section{Não sai do Papel}

"Como explicar tamanha beleza

Se vem de Deus

No lugar da explicação

Deveria existir a contemplação

Um presente, algo vivo e no nosso meio

O seu nome? é a árvore

Pequenas ou grandes enchem nosso meio com beleza, ar puro, frutos e flores (2x)

Prá que devastá-las?

Só pra ostentação dos ricos

Devemos replantá-las!

E reativar os sagrados filtros

Prá que devastá-las?

Só pra ostentação dos ricos

Infelizmente os planos de reflorestamento

Ainda estão no papel

Algumas são polinizadoras, outras ainda,

São fontes de alimento

Mesmo com todas essas utilidades,

Nós insistimos em querer destruí-las

A consciência humana não acordou

E o homem continua a estragar

O que Deus nos deu para auxiliar o dia-a-dia

$A$ vida que está timidamente pronta

Para nos ajudar..." 


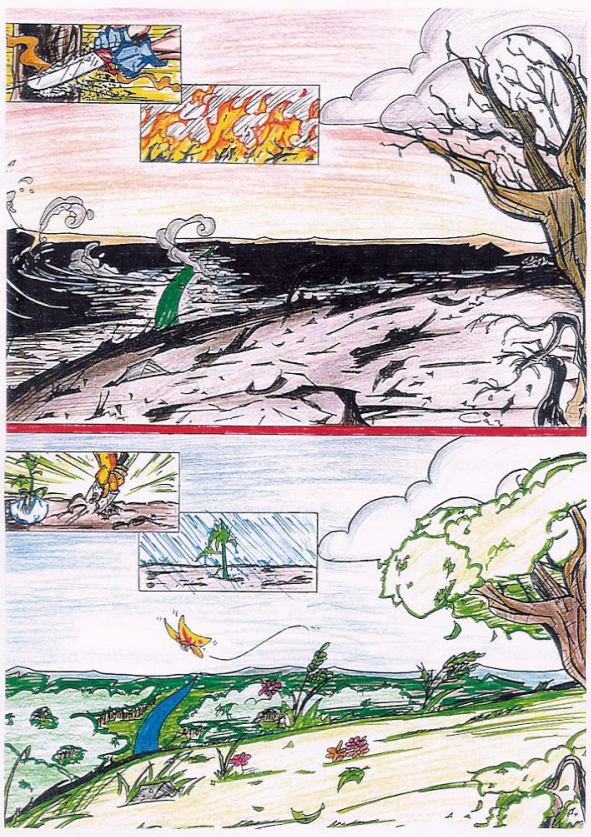

Figura 18 - Desenho de quadrinhos feito por integrante do Grupo de Jovens. 
Tanto o desenho de quadrinhos (figura 18) quanto a letra da música produzida pelos jovens, parecem remeter à "devastação" das florestas, explorando cenas e situações de "desmatamento" e queimadas, apesar do assunto ter sido abordado sempre dentro da situação urbana. Seria a falta de árvores em suas ruas e quintais, percebida em suas fotos, uma das causas dessa dificuldade em retratar e abordar a árvore em seu contexto urbano ou ao contrário, seria aquela falta uma decorrência ou conseqüência dessa dificuldade?...

Porém, verifica-se nos dois casos, o registro de uma postura ativa por parte do ser humano, que partindo de uma situação negativa, de devastação, destruição, de "planos de reflorestamento" que ficam no "papel", assume ser capaz de modificá-la, ao "replantá-la", "ativando os sagrados filtros" e reconhecendo todas as suas "utilidades" e "beleza". No desenho de quadrinhos a alteração drástica de uma paisagem ressequida pela devastação da floresta, cortada pela "moto-serra" e queimada pelo fogo, em um novo cenário verdejante e alegre iniciada pela atitude de plantar uma árvore, também evidencia esta postura ativa e otimista, que se pode considerar, é uma característica inerente aos jovens. 
- Poesia escrita por integrante do Grupo de Terceira Idade:

\section{Dúvidas de um Anjo}

- Meu amado Deus, por que o Senbor fez o ser bumano nascer, crescer, envelbecer e morrer? Digo isso porque en estive lá na terra e encontrei crianças abandonadas, jovens sem sonbos, velbos infelizes e a tal guerra destruindo tudo.

-E a Terra como a encontrou?-Perguntou Deus ao Anjo.

- A Terra, meu Senfor, encontrei quase sem vida, muito devastada. O mundo dos bumanos está morrendo. Viflorestas a cabadas, solos, ar, mar; tudo contaminado; alimentos sendo modificados.

-Então, Anjo, como você quer que as crianças sejam protegioas, jovens cheios de sonbos e velbos felizes? Eu só sou o Pai e dei a natureza como mãe, quando a escolbi para ajudar-me nesta tarefa. Ela educon todos com uma perfeição inabalável, tudo estava em grande barmonia, cada um com suas tarefas. Só que ela, como toda mãe, deixcou de corrigir as falbas na bora, principalmente do homem. E, como fizemos um acordo, nada posso fazer. Dei a elas todos os poderes, menos o de perdoar.

- Men Senbor, pelo que notei a natureza está quase sem forças para controlar seus filbos bumanos.

- A natureza é muito sábia. É certo que el la não perdoa, mas ela é justa e, como toda mãe, está sempre dando outras oportunidades à espécie bumana de corrigir os erros! Eu, anjo dei ao bomem inteligência, dei ao bomem o poder de saber voltar atrás e retomar o caminbo certo. Dei ao homem o sentimento mais precioso: 0 AMOR

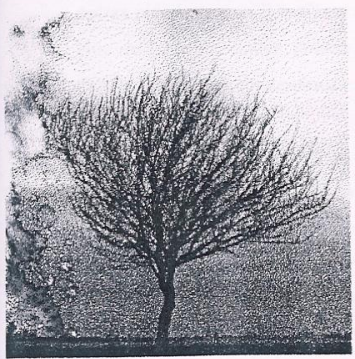

-Sabe, meu Senhor, vi e senti isto nos bomens, não em todos, mas ainda existe em alguns esta vontade de voltar atrás e corrigir. Ainda existe amor. Houre bumanos que avisaram aos outros que Deus perdoa, mas a natureza nunca! Ontros disseram que haverá época em que mal tratar ou dizimar um animal será crime contra a bumanidade.

-Então, Anjo, você pode ver e sentir que Eu só posso encorajar a natureza a não desistir. É o homem que tem o poder de praticar o amor para com a natureza, deixando a terra como criei. Só depende de cada um fazer seu trabalbo.

-Entendi, meu amado Deus. Então não baverá mais crianças abandonadas. Existirão jovens com sonhos e os vellyos serão felizes!

-É verdade, Anjojo poder estâ no bomem!

Dalura Argond 
Esta poesia, escrita anteriormente à pesquisa por uma integrante do grupo de $3^{\text {a }}$ idade, foi apresentada pela autora, que contou ao grupo sobre uma ocasião em que, angustiada, ela chegou à sua rua e encontrou parte das árvores plantadas por ela, sua família e vizinhos naquela praça exposta nas fotos 12 e 13, cortadas pelos novos vizinhos que julgaram que estas árvores tornavam a praça perigosa, por escurecê-la. Revoltada e entristecida, ela deu vazão aos seus sentimentos através desta poesia. Porém, o senso de justiça levou-os, à ela e seus vizinhos que gostam de árvores, a moverem uma ação legal contra os novos moradores que, de forma tão invasiva e autoritária, destruíram um bem coletivo e revestido de grande valor emocional para seus realizadores.

Tanto o contexto no qual foi escrita quanto seu conteúdo revelam um certo sentimento de impotência e tristeza frente à atitudes agressivas para com a natureza, mas demonstram também esperança e otimismo.

\subsubsection{Apresentação de material ilustrativo/slides}

Durante a apresentação de slides com fotos tiradas em bairros da cidade e em outras cidades como Rio Claro e Limeira conversamos sobre as situações registradas. Nos dois grupos houve grande interesse por esse material, que serviu de fonte para muitas reflexões e comentários:

"Puxa, como fica linda uma rua bem arborizada..."

"Realmente, uma cidade arborizada é muito mais bonita."

"Nossa, olha só o que as pessoas fizeram com essa árvore!..."

Considero que esta dinâmica finalizou positivamente a sequência de reuniões ao possibilitar-lhes a aquisição de parâmetros comparativos, onde inúmeras situações negativas e positivas foram apresentadas e discutidas, partindo dos conhecimentos adquiridos e reflexões que eles puderam realizar durante os trabalhos. 


\subsubsection{Questionários}

Foram registradas respostas à 37 questionários, sendo 21 deles respondidos pelos integrantes do grupo de jovens, 07 por integrantes do grupo de $3^{\text {a }}$ idade e somente 9 questionários procedentes das entrevistas realizadas pelos dois grupos (as respostas tabuladas encontram no apêndice 20).

A seguir analisaremos as respostas fornecidas às perguntas do questionário:

- Sobre "a primeira palavra ou o primeiro sentimento que lhe vem à cabeça quando falamos de arborização de rua?":

A grande maioria das respostas expressa-se positivamente em relação ao tema. A palavra "beleza" aparece citada 8 vezes; a palavra "sombra", 4 vezes; "ar" e "ar puro", 3 vezes; sendo que vários sentimentos ou sensações são relacionados: "Amor", "felicidade", "harmonia", "prazer", "essencial", "Vida", "conscientização", "rua bem tratada", etc.

Apenas 3 respostas expressam sentimentos ou sensações negativas: "Lastimável", "a degradação da natureza", "à noite as ruas ficam escuras", em mesmo assim concluise que apenas esta última parece expressar-se negativamente em relação à presença de árvores nas ruas. As duas primeiras expressam um descontentamento com a situação atual de existência de poucas árvores.

- Sobre o conhecimento dos "benefícios que as árvores de rua trazem aos moradores das cidades":

- "Beleza" aparece em primeiro lugar, com 36 respostas.

- "Sombra para os pedestres e carros" é citado em segundo lugar, com 34 respostas.

- "Abrigo para os pássaros", em terceiro lugar, com 32 respostas.

- "As folhas da copa filtram a poeira do ar", quarto lugar, com 25 respostas.

- "Melhoria das condições de saúde física e mental da população", 23 respostas.

- "Redução da poluição sonora e visual", 21 respostas.

- "Redução da velocidade dos ventos", 14 respostas.

- "Redução no consumo de energia com refrigeração dentro das casas", 11 respostas. 
- "Valorização econômica das propriedades", 11 respostas.

"Outros" benefícios foram citadas por oito pessoas, os quais são descritos como:

"Frutos", "lugar para conviver com os vizinhos para um bate-papo", "prazer em cuidálas, sempre melhorar, conservar o meio-ambiente", "flores", "humanização da paisagem urbana", "ajudar na preservação da espécie" e "contribui para a ecologia".

Nota-se que alguns bene fícios como "valorização econômica das propriedades", "redução no consumo de energia com refrigeração dentro das casas" e "redução da velocidade dos ventos" são menos conhecidos, enquanto os demais benefícios apontados na pesquisa são mais evidentes.

- 18 pessoas possuem árvore e 19 pessoas não possuem.

- Das que possuem, 9 delas sabem dizer o nome da espécie e 10 delas não sabem.

- 13 pessoas sabem dizer a idade da árvore e 06 pessoas não sabem.

- Todas afirmam "gostar" de possuir a árvore em frente de casa. Os motivos para gostar falam de "sombra", "beleza", "filtra o ar", "contribui com a natureza", "necessidade", etc.

- Das 19 pessoas que responderam que não têm árvore plantada em frente de casa, os motivos para não ter vão desde problemas com danos à calçada (citado em primeiro lugar), pela sujeira que elas provocam, não desejar que vizinhos estacionem em frente à sua garagem, nunca pensaram a respeito até a não possuir espaço para plantar.

- As pessoas que não possuíam árvore foram questionados se gostariam de ter uma árvore plantada em frente de casa: 14 pessoas responderam que sim, 02 pessoas responderam que não, 03 não responderam.

O Ipê aparece em primeiro lugar em sua preferência. 


\subsubsection{Conclusões sobre os resultados da pesquisa com arborização:}

Os resultados observados através da dinâmica "Árvore da Esperança" demonstram que este segmento da população piracicabana percebe o tema "arborização" como sendo um dos elementos mais importantes a compor a "rua ou o bairro" desejado por eles. Anseiam por uma arborização mais evidente, abundante, colorida (flores), bem tratada, sendo que alguns deles demonstraram o desejo de que haja espécies frutíferas nas ruas.

O "Muro das Lamentações" permitiu verificar que os problemas causados pelas árvores mais percebidos por aquelas pessoas são a quebra ou danificação do calçamento viário, a sujeira provocada pela queda de folhas e flores, a interferência na rede elétrica e o entupimento de calhas, também provocado pela queda de folhas e flores das árvores. Por outro lado a discussão e busca de alternativas à estes problemas realizada nos dois grupos demonstrou que esses moradores são pré-dispostos à reconsiderar as questões levantadas, tendo em vista as possíveis soluções apontadas e que não implicariam no sacrifício da árvore.

A "beleza" e a "sombra" da árvore são os itens mais percebidos por esses moradores, confirmando-se o primeiro item através da predileção manifestada pelo Ipê, espécie florífera de grande beleza ornamental. Daqui deriva-se que uma arborização caracterizada por um número excessivo de arbustos e árvores de pequeno porte não satisfarão o segundo item e que espécies de florescimento vistoso devem ser priorizadas para atender ao primeiro.

Por fim, os exercícios de exploração do bairro e da história de suas árvores, as atividades artísticas e reflexivas, aliadas à apreciação, através de slides e fotos, de cenários com pouca ou nenhuma árvore, situações de maus tratos, como podas destruidoras e anelamentos criminosos, e de paisagens compostas por muitas e frondosas árvores, calçadas verdes, ruas e avenidas enfeitadas por árvores, acrescida do fornecimento pela pesquisadora, de informações sobre os benefícios que as árvores trazem ao ambiente urbano, pareceu estimular ou fazer emergir um "olhar" de 
reconhecimento, favorável, tolerante e, porque não dizer, muito "afetuoso" e "amoroso" para com as árvores.

"fora de dúvida, uma pesquisa de percepção é capaz de flagrar signos que nos ajudam a ver de outro modo a nossa realidade e leva a uma espécie de alfabetização urbana em que os problemas físicos e estruturais empalidecem ante a urgência de uma ação cultural que se impõe ao desenho urbano e deve vetorizar a intervenção pública." Ferrara (1993, p 126).

\subsubsection{Conclusão sobre os efeitos da pesquisa participante nos grupos:}

De um modo geral, foi possível perceber que a utilização do processo participativo durante a pesquisa favoreceu a conquista de maior autonomia e união (principalmente no grupo de jovens), o aumento da percepção sobre seu meio ambiente, com o sentimento de apropriação e co-responsabilidade por seus espaços coletivos, trazendo à tona um potencial para pensar e agir sobre sua realidade.

Por seus efeitos, a participação pode ser considerada como uma metodologia e um objetivo da educação ambiental.

Quanto à iniciativas para continuidade dos trabalhos com relação à arborização de seu bairro, verificou-se que foi maior no grupo de jovens, que já era organizado com rotina de reuniões definidas e com a maioria de seus integrantes residindo no mesmo bairro ou em bairros próximos. Já no grupo de terceira idade, onde essas características de grupo não estavam presentes, não houve iniciativa de continuidade.

As diferenças de idade revelam focos de interesse diferentes. No grupo de jovens o humor esteve sempre presente, incentivando a participação e quebrando resistências, enquanto no grupo de terceira idade a possibilidade de relatar a experiência/sabedoria adquirida ao longo da vida estimulou-os à participar ativamente das discussões.

A seguir descrevo de forma mais detalhada sobre efeitos da pesquisa participante dois grupos. 


\section{No Grupo de Jovens da Igreja São Judas:}

Houve grande receptividade à metodologia empregada, sendo que seus membros participaram ativamente das dinâmicas aplicadas. À princípio esta participação foi se manifestando de maneira um pouco mais tímida, porém tornou-se bem mais intensa à medida que o interesse pelo tema aumentava.

Percebi que os jovens exploraram o lado cômico das situações apresentadas, rindo de suas próprias piadas o tempo todo, transformando alguns problemas em piadas irônicas e divertidas e este senso de humor elevado quebrou as resistências iniciais.

Observei também que, durante as atividades, foi surgindo um crescente interesse por outros temas relacionados ao seu meio ambiente, principalmente os relacionados com a questão do lixo, como por exemplo a reciclagem e o acúmulo de lixo em trilhas ecológicas.

Sobre a questão da arborização viária de seu bairro, as dinâmicas e atividades desempenhadas por eles suscitou no grupo um interesse muito grande pelo tema, sensibilizando-os a ponto de provocar o desejo de agirem sobre sua realidade.

Realizei quatro reuniões com este grupo, num período de três a quatro meses. A idéia inicial era de reuni-los apenas duas vezes para a realização da pesquisa participativa e coleta dos dados, porém a empolgação natural dos jovens não poderia deixar de se fazer presente, e desejaram elaborar um projeto de arborização para o bairro onde está situada a Igreja São Judas.

Os quatro integrantes da banda que apresentou a música sobre o tema, se propuseram a coordenar o projeto. O processo de criar e interpretar uma música sobre o tema os estimulou bastante, e além disso outros integrantes do grupo, inclusive mais jovens (entre 15 e 17 anos) manifestaram o interesse em participar da coordenação. Um dos jovens relatou-me que sentia falta de algo pelo que lutar, um desafio, um trabalho que revertesse para a sociedade, e que agora se sentia muito entusiasmado com a perspectiva da fazer algo pelo bairro através do projeto.

Procurei deixar claro desde o início que a minha participação se limitaria à obtenção dos dados necessários à minha pesquisa, e que qualquer iniciativa de trabalho 
com relação ao tema teria apenas a minha colaboração, pois o importante e o que eu pretendia com o método empregado, era favorecer que eles "tomassem posse de seus problemas e buscassem por si mesmos as soluções”. Assim, após o surgimento do desejo coletivo de realizar um trabalho de arborização do bairro, evitei assumir posturas paternalistas o máximo que pude, indicando caminhos, porém não tomando à frente em nenhuma situação. Após o término das atividades com a pesquisa sobre arborização coloquei-me à disposição para colaborar no que fosse preciso, e cheguei a assumir algumas tarefas em conjunto com alguns jovens do grupo.

Porém, talvez a pouca experiência em iniciativas deste tipo e a falta de informação sobre o tema, aliadas à sua pouca maturidade e à cultura paternalista comum em seus meios sociais, familiares, profissionais, etc, deixou-os bastante inseguros. Além disso a maioria deles trabalha durante o dia e estuda à noite, restando os finais de semana para empenhar-se em projetos como esse.

Desta forma, algumas tarefas iniciais acordadas em conjunto não foram realizadas pelas pessoas que as assumiram, e eu me mantive na espera de que eles me procurassem para dar seguimento, porém isso não ocorreu.

De fato o grupo, que nesta fase se achava bastante unido, acabou envolvendo-se em outras atividades patrocinadas pela paróquia a qual faziam parte, como organização de festas da Igreja entre outras coisas. Além disso, alguém no grupo acabou sugerindo que adiassem o projeto para o período de eleições, no ano seguinte, onde poderiam conseguir apoio de candidatos.

Por outro lado, esta "união" foi relatada por membros do grupo como um fato novo, e possivelmente motivada por uma modificação da estrutura hierárquica do grupo, que antes se apresentava de forma um tanto paternalista e centralizada na figura de um coordenador, um jovem de 27 anos, mais velho que a maioria de seus integrantes, e agora cedia lugar a um sistema mais descentralizado e participativo. Comentam que agora estão dividindo mais as funções que antes ficavam muito concentradas nas mãos do coordenador. Integrantes do grupo que antes participavam de forma displicente ou desinteressada, passaram a envolver-se mais com o grupo e suas atividades. 


\section{No grupo de $3^{\text {a }}$ Idade da ESALQ:}

Conforme foi relatado anteriormente, apesar de ter-se distribuído uma grande quantidade de convites, poucas pessoas participaram das reuniões.

Enquanto no grupo de jovens destacourse o componente humorístico, incentivando a participação de seus membros, no grupo de $3^{\mathrm{a}}$ idade, pode-se dizer que o desejo de manifestar as experiências e aprendizados pessoais foi um fator marcante, que estimulou a participação ativa de todos eles.

Aqui também existiu grande receptividade ao método utilizado, porém houve menos envolvimento com as tarefas propostas para serem realizadas por eles durante a semana, que no grupo de jovens, talvez pelo número menor de participantes.

Questionaram-me se faríamos algum trabalho prático sobre o tema e respondi dizendo que dependeria deles manifestarem esse desejo, e que minha participação seria como colaboradora. Porém esse desejo não foi expressado e encerramos as atividades da pesquisa após a segunda reunião. 


\section{CONCLUSÃO}

\subsection{Considerações finais e sugestões}

Num mundo sem mitos, onde as árvores e bosques sagrados do passado pouco ou nada significam, os seres humanos defrontam-se com a grave crise ambiental, social e espiritual na qual encontram-se mergulhados.

Se por um lado a natureza é negada e subjugada, principalmente no ambiente das cidades, e o isolamento dos indivíduos à desfrutar de suas posses materiais no interior de suas casas os privam da experiência coletiva, por outro lado o vazio de suas existências os impele a uma busca sem precedentes pelo sentido da vida e pelo equilíbrio harmônico com a natureza.

A arborização de uma cidade é um tema e a educação ambiental uma ferramenta. Juntos, tema e ferramenta, são possibilidades de transformação, portas de entrada para o resgate de sensibilidades e de mitos perdidos ou esquecidos na história dos humanos neste planeta.

Assim, tendo em vista estes referenciais e os resultados alcançados nesta pesquisa, apresento algumas reflexões que poderiam ser tomadas como sugestões para os que trabalham ou pretendem trabalhar com árvores:

Trabalhar com o tema "árvore" é defrontar-se com um leque de infinitas possibilidades de abordagens, pois o sentido da relação entre seres humanos e as árvores é profundamente simbólico e espiritual. No entanto, verifica-se que as abordagens técnicas têm prevalecido soberanas nos processos de planejamento e gerenciamento da arborização de cidades. Aos políticos, engenheiros e técnicos responsáveis por sua 
condução falta um olhar mais filosófico sobre a questão. Como esperar da população sentimentos de reverência, respeito, tolerância e afeto por seres que são lançados como "postes" pela cidade, arrancados e trocados como elementos supérfluos, podados e negligenciados como seres inconvenientes e destituídos de vida?

É preciso que haja entre as equipes responsáveis por essa arborização um comprometimento verdadeiro com a árvore. Seus conceitos técnicos precisam ser amparados por uma visão afetiva e amorosa sobre elas. Os atos de plantio deveriam constituir-se em rituais de vida, capazes de suscitar entre os moradores que recebem as novas mudas de árvores, sentimentos de afeto e amor pelo novo ser vivo que vai compor sua paisagem e que dependerá, para sobreviver, de cuidados especiais.

Portanto, pensar numa educação ambiental provocadora de mudanças transformadoras, é pensar que esta educação deve antes de mais nada atingir aqueles que são responsáveis tecnicamente e politicamente por determinada situação problemática. A velha "educação de cima para baixo" já foi há muito colocada em xeque, justamente porque percebeutse que é impossível ensinar somente através da teoria. É preciso dar exemplos. Em outras palavras, para ensinar o respeito, a reverência e o amor é preciso tê-los, ou estar desenvolvendo-os dentro de si.

Por isso acredito que a realização de projetos educativos sobre temas como arborização deve ser pensada como um processo abrangente, que inicia-se com um "reolhar" sobre as motivações, crenças, conceitos e valores dos próprios envolvidos no seu desencadeamento. Somente a partir daí o processo deve atingir a população que se pretende "educar".

Por último, como sugestões mais pontuais recomendo:

- que setores da sociedade envolvidos com as questões ambientais (ONG's, Universidades, etc) passem a cobrar com maior intensidade ações que beneficiem a qualidade da arborização urbana em Piracicaba;

- que a legislação, atualmente falha e imprecisa em alguns pontos, seja revista e modificada adequadamente, e que seja rigorosamente cumprida; 
- que seja realizado o inventário da população arbórea da cidade;

- que se criem mecanismos de incentivos fiscais, como redução no IPTU, para estimular o plantio de árvores em calçadas e áreas particulares;

- que as equipes técnicas sejam fortalecidas em sua autonomia e estrutura, para que possam definir e implementar diretrizes mais comprometidas com a arborização urbana e seus benefícios ambientais, em detrimento de pressões políticas e de um segmento da população que, no momento, relaciona-se mal com esta arborização;

- que estas equipes sejam estimuladas à uma formação filosófica a respeito do tema e que se aprofundem mais nos conceitos e propósitos da educação ambiental, a fim de utilizá-la em todas as etapas de seus trabalhos, tendo em vista o alcance de objetivos amplos de conscientização e desenvolvimento humano;

- que estas equipes passem a se utilizar de processos participativos no planejamento e execução de projetos de arborização urbana e nos demais projetos relativos à seus espaços coletivos;

- que os moradores sejam orientados (através de cartilhas, jornais, tv local, rádios, escolas, palestras, etc) sobre como cuidar das árvores, para evitar manejos (como poda, cimentação do colo, etc) que possam comprometer a sanidade das árvores acarretando em transtornos futuros;

- que as campanhas educativas estimulem o envolvimento afetivo entre pessoas e árvores, sendo direcionadas aos públicos distintos (crianças, jovens, adultos e $3^{\text {a }}$ idade) e que enfoquem valores como tolerância, respeito, amor e reverência pelas árvores;

- os itens " beleza", "sombra" e "ar puro" são os mais percebidos ou valorizados pelo segmento da população pesquisado, e poderiam ser incorporados com muita intensidade nos projetos e campanhas educativas;

- que haja maior participação das universidades presentes em Piracicaba nos assuntos relativos à arborização urbana e qualidade ambiental, mediante a 
clara definição e apresentação das demandas existentes pelos setores responsáveis. 


\section{REFERÊNCIAS BIBLIOGRÁFICAS}

ADAMS, E. Aprendendo a ver. In: BARBOSA, A.M. Tópicos Utópicos. Belo Horizonte:C/Arte, 1998. 200p.

ALMEIDA, J.R. Planejamento ambiental: caminho para participação popular e gestão ambiental para nosso futuro comum, uma necessidade, um desafio. Rio de Janeiro: Ed. Thex,1993. 176p.

ALVES, A.J. O planejamento de pesquisas qualitativas em educação. Cadernos de Pesquisa, n.77, p.53-61, 1991.

AMES, R.G. The sociology of urban tree planting. Journal of Arboriculture, v.6,n.5, May 1980. p.120-123.

AVELINE, C.C. Ecologia interior. Revista Planeta, n.2, p.53, fev.99.

BAPTISTA, L.R. M. O ciclo vital das árvores. In: BATISTA, L.R.M. (Org.) A magia das árvores. Porto Alegre: Riocell, 1995. p.71.

BARBOSA, S.R.C.S. Ambiente, qualidade de vida e cidadania. Algumas reflexões sobre regiões urbano-industriais. In: HOGAN, J.D.; FREIRE, P. (Org.) Dilemas sócioambientais e desenvolvimento sustentável. 2.ed. Campinas: UNICAMP, 1995. p.110-116.

BECKER, H.S. Métodos de pesquisa em ciências sociais. 2.ed. São Paulo: Hucitec, 1993. 178p.

BIANCHI, C.G.; GRAZIANO, T.T. Caracterização e análise das áreas verdes urbanas de Jaboticabal-São Paulo. In: CONGRESSO BRASILEIRO SOBRE ARBORIZAÇÃO URBANA, 1., Vitória, 1992. Anais. Vitória: Prefeitura, 1992, p. 225-237. 
BORDENAVE, J.E.D. O que é participação. 3.ed. São Paulo: Brasiliense, 1985. 84p. BORDENAVE, J.E.D. O que é participação. 4.ed. São Paulo: Brasiliense, 1994. 84p. BROWN, N.O. Dafne ou Metamorfose. In: CAMPBEL, J. Mitos, sonhos e religião: nas artes, na filosofia e na vida contemporânea. Rio de Janeiro: Ediouro, 2001. p.93-110.

BUENO, O.C.; SOUZA, M.A.L.; MARCONDES, A.L. Rearborização da área central do município de Botucatu-SP: um projeto em parceria. In: ENCONTRO NACIONAL SOBRE ARBORIZAÇÃO URBANA, 5., São Luis, 1994. Anais. São Luis: SBAU, 1994. 1v.

CAMPBELL, J. O poder do mito. São Paulo: Palas Athena, 1990. 250p.

CARVALHO, I.C.M. Educação, meio ambiente e cidadania. In: CONGRESSO NACIONAL SOBRE ESSÊNCIAS NATIVAS, 2., São Paulo, 1992. Anais. São Paulo: Instituto Florestal, 1992. p.1081-1085.

CAVALHEIRO, F. Arborização urbana: planejamento, implantação e condução. CONGRESSO BRASILEIRO DE ARBORIZAÇÃO URBANA, 2., São Luiz, 1994, Anais. São Luis: SBAU, 1994. p.227-231.

CHIZZOTTI, A. Pesquisa em ciências humanas e sociais. São Paulo: Cortez, 1991. $79 \mathrm{p}$.

CHOPRA, D. Como conhecer Deus : a jornada da alma ao mistério dos mistérios. Rio de Janeiro: Rocco, 2001. 383p.

COELHO, M.I.M. Programa integrado de pesquisa. http:/netpage.em.com.br/mines (06 Nov. 2001).

DENZIN, N. K. Sociological methods : a sourcebook. Chicago: Aldine, 1970. 590p.

DETZEL, V.A. Avaliação monetária e de conscientização pública sobre arborização urbana: aplicação metodológica à situação de Maringá-Pr. In: CONGRESSO BRASILEIRO DE ARBORIZAÇÃO URBANA, 2., São Luis, 1994. Anais. São Luis: SBAU, 1994. p.49-65. 
DINIZ, C.C. Elaboração participativa de um plano de gestão em educação ambiental para o Campus "Luiz de Queiróz"/Universidade de São Paulo. Piracicaba, 1999. 353p. Dissertação (Mestrado) - Escola Superior de Agricultura "Luiz de Queiróz", Universidade de São Paulo.

FERRARA, L.D. Olhar periférico: informação, linguagem, percepção ambiental. São Paulo: EDUSP, 1993. 277p.

FERREIRA, L.C.; JACOBI, P. As cidades e a sustentabilidade. Revista Debates Sócio Ambientais/Agenda 21 e Desenvolvimento Sustentável, n.11, p.6, nov./fev. 1998/1999.

FRANCO, A. Ação local: a nova política da contemporaneidade. São Paulo: Ágora; Instituto de Política; FASE, 1995. 224p.

FRANCO, M.A.R. Desenho ambiental: uma introdução à arquitetura da paisagem com o paradigma ecológico. São Paulo: Annablume, 1997. 224p.

GEISER, R.R. Áreas verdes nas grandes cidades. São Paulo: Sociedade Brasileira de Paisagismo, 1975. 5p.

GOYA, C.R. Os jardins e a vegetação no espaço urbano: um patrimônio cultural. In: CONGRESSO BRASILEIRO DE ARBORIZAÇÃO URBANA, 2., São Luis, 1994. Anais. São Luis: SBAU, 1994. p.133-145.

GUEVARA, A.J.H. As relações entre o natural e o artificial e suas implicações educacionais. In: GUEVARA, A.J.H. (Org.) Conhecimento, cidadania e Meio ambiente. São Paulo: Peirópolis, 1998. p.91.

GUIMARÃES, R. P. Agenda 21 e desenvolvimento sustentável: o desafio político da sustentabilidade. Revista Debates Sócio Ambientais/Agenda 21 e Desenvolvimento Sustentável, n. 11, p.1, nov./fev. 1998/1999.

GUTIERREZ, F.; Prado, C. Ecopedagogia e cidadania planetária. São Paulo: Cortez; Instituto Paulo Freire, 1999. 128p. 
HAGUETTE, T.M.F. Metodologias qualitativas na sociologia. Rio de Janeiro: Vozes, 1992. v.1.

HOCK, S.S.; MENDONZA, I. As sete riquezas do homem santo. São Paulo: Axis Mundi; Associação Ad Lumen de Filosofia Oriental, 2000. 110p.

HOPPEN, N.; LAPOINTE, L.; MOREAU, E. Um guia para a avaliação de artigos de pesquisa em sistemas de informação. www://http/read.adm.ufrgs.br/read03/ (07 Nov. 2001).

HOPPER, S. R. Mito, sonho e imaginação. In: CAMPBEL, J. Mitos, sonhos e religião: nas artes, na filosofia e na vida contemporânea. Rio de Janeiro: Ediouro, 2001. p.155-165.

HOWARD, E. Cidades-jardins de amanhã. São Paulo: Hucitec, 1996. 211p.

INSTITUTO ECOAR PARA A CIDADANIA. Agenda 21 do pedaço. São Paulo: Consórcio Cógito; Instituto Ecoar para a Cidadania; SVMA-Secretaria Municipal do Verde e do Meio Ambiente, 1997. 16p.

LACHANCE, A. Espiritualidade verde : doze lições sobre espiritualidade ecológica: uma terapia individual, cultural e planetária. São Paulo: Gaia, 1996. 287p.

LAGO, A.; PÁDUA, J.A. O que é ecologia. 9. ed. São Paulo: Brasiliense, 1989. $108 \mathrm{p}$.

LEIS, H.R. O labirinto: ensaios sobre ambientalismo e globalização. São Paulo: Gaia; Blumenau: Fundação Universidade de Blumenau, 1996. 171p.

LIMA, A.M.L.P. Piracicaba/SP: análise da arborização viária na área central e em seu entorno. Piracicaba, 1992. 238p. - Tese (Doutorado) - Escola Superior de Agricultura "Luiz de Queiróz", Universidade de São Paulo.

LIMA, A.M.L.P; CAVALHEIRO, F.; CAMPOS, S.A. As áreas verdes de Piracicaba. In: ENCONTRO NACIONAL SOBRE ARBORIZAÇÃO URBANA, 3., Curitiba, 1990. Anais. Curitiba: FUPEF, 1990. p.181-187. 
LIMA, A.M.L.P.; COUTO, H.T.Z.; ROXO, J.L.C. Análise das espécies mais freqüentes da arborização viária, na zona urbana central do município de Piracicaba/SP. In: CONGRESSO BRASILEIRO DE ARBORIZAÇÃO URBANA, 2., São Luis, 1993. Anais. São Luis: SBAU, 1993. p.555-573.

LORENZI, H. Árvores brasileiras. Nova Odessa: Plantarum, 1992. 368p.

LÜDKE, M.; ANDRÉ, M.E.D.A. Pesquisa em educação: abordagens qualitativas. São Paulo: E.P.U., 1986. 100p.

MAFFESOLI, M. Elogio da razão sensível. Petrópolis: Vozes, 1998. 207p.

MALINSKY, R. Arborização: uma visão integrada. In: ENCONTRO NACIONAL SOBRE ARBORIZAÇÃO URBANA, 1., Porto Alegre, 1985. Anais. Porto Alegre: SEMA, 1985. p.37-38.

MARQUES, M.O. O discurso do método. Revista Contexto \& Educação, Práticas Sociais Transformadoras, v.1 n.2, p.6, abr./jun. 1986.

MEDINA, M. N. Breve histórico da educação ambiental. In: PADUA, S.M.; TABANEZ, M.F. (Org.) Educação ambiental: caminhos trilhados no Brasil. Brasília: Instituto de Pesquisas Ecológicas, 1997. p.256.

MILANO, M.S. A cidade, os espaços abertos e a vegetação. In: CONGRESSO BRASILEIRO SOBRE ARBORIZAÇÃO URBANA, 1.,Vitória, 1992. Anais. Vitória: Prefeitura, 1992. p.3-14.

MILANO, M.S. Arborização urbana: plano diretor. In: CONGRESSO BRASILEIRO DE ARBORIZAÇÃO URBANA, 2., São Luis, 1994. Anais. São Luis: SBAU, 1994. p.207-215.

MILANO, M.S. Arborização urbana no Brasil: mitos e realidade. In: CONGRESSO BRASILEIRO DE ARBORIZAÇÃO URBANA, 3., Salvador, 1996. Anais. Salvador: SBAU. 1v.

MINAYO, M.C.S. Pesquisa social: teoria, método e criatividade. Rio de Janeiro: Vozes, 1996. v.1. 
MOHR, U. A cidade, os espaços públicos e a vegetação. In: ENCONTRO NACIONAL SOBRE ARBORIZAÇÃO URBANA, 1., Porto Alegre, 1985. Anais. Porto Alegre: SEMA, 1985, p.31-35.

MOLL, G. Trees and green areas in urban environments. In: WORLD FORESTRY CONGRESS, 10., Paris, 1991. Acta. Paris: s. ed., 1991. p.335-339.

OLIVEIRA, R.D.; OLIVEIRA, M.D. Pesquisa social e ação educativa: conhecer a realidade para poder transformá-la. In: BRANDÃO, C.R. Pesquisa participante. São Paulo: Brasiliense, 1982. p.17-41.

PATTON, M. Q. Qualitative evaluation and research methods. New York: Sage, 1990. v.1.

PEGORARO, J.L. Educação ambiental: a temática da flora, da fauna e dos ambientes naturais (expressões da biodiversidade) a partir da educação formal. Piracicaba, 1998. 203p. Dissertação (Mestrado) - Escola Superior de Agricultura "Luiz de Queiróz", Universidade de São Paulo.

PREFEITURA DO MUNICÍPIO DE PIRACICABA. Arborização de ruas e avenidas de Piracicaba. Piracicaba: CALQ, 1969/70. 58p.

QUIVY, R.; CAMPENHOUDT, L. Manual de investigação em ciências sociais. Lisboa: Gradiva Publicações, 1988. 275p.

RANZANI, G. Subsídios à geografia de piracicaba. Piracicaba: Instituto de História e Geografia de Piracicaba, 1976. 1v.

SANCHOTENE, M.C. Desenvolvimento e perspectivas da arborização urbana no Brasil. In: CONGRESSO BRASILEIRO DE ARBORIZAÇÃO URBANA, 2., São Luis, 1994. Anais. São Luis: SBAU. p.15-25.

SATTLER, M.A. Arborização urbana e conforto ambiental. In: ENCONTRO NACIONAL SOBRE ARBORIZAÇÃO URBANA, Vitória, 1992. Anais. Vitória: Prefeitura, 1992. p.15-28.

SCHAMA, S. Paisagem e memória. São Paulo: Companhia das Letras, 1996. 645p. 
SCHULER, D. As raízes da simbologia. In: BATISTA, L.M. (Org.) A magia das árvores. Porto Alegre: Riocell, 1995. p.74-101.

SILVA,S.A.P.S. A pesquisa qualitativa em educação física. http://www.efmuzambinho.org.br/refelnet/revusp/edições/1996/uspv/on1/8sheil.htm (06 Nov. 2001).

SOARES, M.P. Verdes urbanos e rurais: orientação para arborização de cidades e sítios campesinos. Porto Alegre: Cinco Continentes, 1998. 242p.

SORRENTINO, M. Educação ambiental e universidade: um estudo de caso. In: PADUA, S.M.; TABANEZ, M.F. (Org.) Educação ambiental: caminhos trilhados no Brasil. Brasília: Instituto de Pesquisas Ecológicas, 1997. p.96-115.

SORRENTINO, M. Crise ambiental e educação. In: QUINTAS, J.S. (Org.). Pensando e praticando a educação na gestão do meio ambiente. Brasília: Instituto Brasileiro do Meio Ambiente e dos Recursos Naturais Renováveis, 2000a. p.94-104.

SORRENTINO, M. De Tbilisi a Thessaloniki: a educação ambiental no Brasil. In: QUINTAS, J.S. (Org.). Pensando e praticando a educação na gestão do meio ambiente. Brasília: Instituto Brasileiro do Meio Ambiente e dos Recursos Naturais Renováveis, 2000b. p.106-114.

SOUZA, H. M. Arborização urbana em Campinas-SP. O Estado de São PauloSuplemento Agrícola, 08 set.1982. p.5.

SPIRN, AW. O jardim de granito: a natureza no desenho da cidade. São Paulo: EDUSP, 1995. 326p.

STAKE, R.E. Pesquisa qualitativa/naturalista: problemas epistemológicos. Educação e Seleção, n.7, p.6, jan./jun. 1983.

TAKAHASHI, L.Y. Importância do inventário. In: CONGRESSO BRASILEIRO DE ARBORIZAÇÃO URBANA, 2., São Luis, 1994. Anais. São Luis: SBAU, 1994. p.193-198. 
TASSARA, E.T.O.; TASSARA, M.; SORRENTINO, M.; TRAJBER, R. Propostas para a instrumentalização de uma educação ambiental transformadora. In: BARBOSA, L.; TRAJBER, R. (Org.). Avaliando a educação ambiental no Brasil: materiais audiovisuais. São Paulo: Peirópolis; Instituto Ecoar para a Cidadania, 2001. p.5667.

THOMAS, K. O homem e o mundo natural: mudanças de atitude em relação às plantas e aos animais. São Paulo: Companhia das Letras, 1988. 454p.

THILlENT, M. Metodologia da pesquisa-ação. São Paulo: Cortez, 1985. 108p.

TROPPMAIR, H. Estudo biogeográfico das áreas verdes de duas cidades médias do interior paulista: Piracicaba e Rio Claro. Rio Claro: UNESP; Geografia, 1976. $78 \mathrm{p}$.

TUAN, YiFu. Topofilia: um estudo da percepção, atitudes e valores do meio ambiente. São Paulo: Difel-Difusão Editorial, 1980. 288p.

UNESCO. Educação ambiental: as grandes orientações da conferência de Tbilisi. Brasília: Instituto Brasileiro do Meio Ambiente e dos Recursos Naturais Renováveis, 1997. 69p.

VIANA, R.M.; HÖEFFEL, J. L. A ecologia do amor. In: GUEVARA, A.J.H. (Org.) Conhecimento, cidadania e meio ambiente. São Paulo: Peirópolis, 1998. 91p.

VIEZZER, M.L.; OVALLES,O. Manual latino-americano de educação ambiental. São Paulo: Gaia, 1994. v.1.

YIN. R. K. Case study research: design and methods. Tradução e síntese de R.L. Pinto. http://www.fea.usp.be/metodologia/estudo_caso.asp/ (06 Nov. 2001). 
APÊNDICES 
APÊNDICE 01 - Jornal de Piracicaba, 29/01/1996

Cidade tem poucas áreas

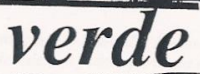

O ideal seria que Piracicaba tivesse cerca de $20 \%$ de cobertura vegetal

Piracicaba é uma cidade onde a cobertura vegetal apresenta um dos indices mais ineficientes do Estado.

Com apenas $2.5 \%$ de áreas verdes plantadas. o municipio deveria ter, no mínimo. $20 \%$ de seu território atingido por espécies arbóreas e matas ciliares, conforme explica o presidente da Sodemap (Snciedade para a Defesa do Mcio Ambiente de Piracicaba). Paulo Kageyama. A deficiência atinge em igualdade de condiçỏes tanto a zona urbana como a rural.

Entre os bencficios mais importantes de uma cohertura vegetal eficiente segundo Kageyama. é a estabilidade das temperaturas, que se tornam mais estáve is com a presença de árvores e espécies verdes. Elas absorvem a luminosidade do sol e nảo provocam o "abafamento" das temperaturas. Entre uma área vegetal coberta e outra nāo-coberta. a diferença são de mais de três graus centigrados

So para se ler uma idéia da fâtta de vegetação em Piracicaba. o Es- tado de São Paulo conta atualmente com cerca de $7 \%$ de cobertura vegetal, o que ainda representa um déficit considerável e desigual, em comparação com as demais regiões do pais, de acordo com o Paulo Kageyama, da Sodemap.

Para tentar minimizar o problema e repôr as áreas com ărvores. a Secretaria Estadual do Meio Ambiente está organizando uma campanha para que a cobertura chegue a $20 \%$ no Estado. En Piracicaba, o plantio de árvores é possível através do viveiro de mudas mantido pela Sodemap com o auxílio da Universidade Metodista de Piracicaba (Unimep).

Por ano, conforme observa Kageyama, a capacidade do viveiro, instalado no campus Taquaral, chega a 50 mil mudas nativas. O interessante é que o programa é voltado diretamente à população. que tem acesso às mudas e pode plantá-las como quiser nas residências, proporcionando um aumento no número de árcas verdes existentes na cidade.

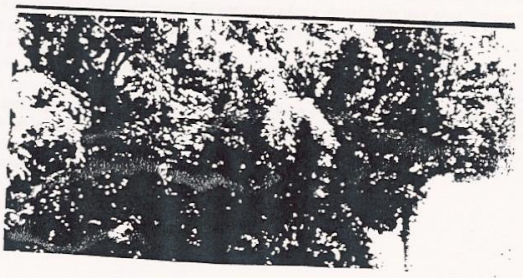




\section{APÊNDICE 02 - Transcricão de "Oficina de Futuro" - PROCAV}

"O que está funcionando mal?

O lugar onde a gente vive e passa boa parte do tempo é muito importante. Por isso, quando existe alguma coisa que incomoda precisa fazer algo para resolver. O primeiro passo é definir muito bem quais são os

"Aitvidade no. 1: Muro das Lamentações: O Muro das Lamentações fica na cidade velha de Jerusalém. Com a destruição do Templo de Herodes, os judeus partiram da Palestina, mas sempre voltavam em cercava o templo. Ainda hoje, nos vãos das pedras claras a única pare de que restou: um muro que bilhetinhos com seus sofrimentos e sonhos. "( p. 7

Como gostariamos que este lugar fosse?

Agora que ja escolhemos, entre todas as lamentações, aquelas que podemos começar a resolver, vamos pensar no que é necessário para encontrar as soluções. Mas, antes, vamos sonhar um pouquinho? Quais
são os nossos sonhos e os nossos desejos para o futuro?

Atividade n. 2: Arvore da Esperança: Antes de começar a Rio-92, pessoas de todo o mundo escreveram seus sonhos de futuro em um papel com forma de folha. Essas folhas foram penduradas nos galhos de uma árvore gigante, que foi instalada na praia do Flamengo, no rio de Janeiro, como símbolo da Vale a pena pensar a mats feliz para todos

vamos escrever ou mesmo desen que achamos importante para melhorar a vida no nosso pedaço. Depois Agora, vamos conversar sobre os nos nossos sonhos e pendurar na Árvore da Esperança.

objetivos para alcançar no final da nossa viagem. (10)

Como Iremos chegar lá? Quando já sabemos para onde ir, só falta chegar lá. Que caminhos deve seguir a Oficina de futuro para
alcançar os nossos sonhos?

Já temos nossos problemas e conhecemos nossos sonhos. Sabemos também que os problemas e dificuldades têm uma história própria, diversas razòes para estarem ấ. Razôes que temos que conhecer deles existirem? de várias maneiras. Podemo pedaço: Vamos recuperar um pouco da nossa memória? Isso pode ser feito nosso pedaço. Essas pessoas podem contar um possoas mais velhas, aquelas que vivem há mais tempo no qualquer tipo de material que possa ajudar-nos a con de história, mostrar fotografias, quadros, vale Com essas informaçães e com o materiat de fos a contar a história do nosso pedaço.

de dados sobre a comunidade e uma bela exposicono hidtónica do peda dar inicio à montagem de um banco gravados ou escritos, as fotografias podem ser copiadas e devolvidas aos seus donos, os podem ser qualquer tipo de material precisam ser estudados com cuidado Como é Hoje o nosso pedaço?

Vamos voltar ao problema que decidimos solucionar no pedaço. Já sabemos como ele apareceu, qual a sua história e agora precisamos entender qual é a situação atual. Para isso mais uma vez é importante Ter acesso a todo tipo de informações relacionadas com o problema. Ajuda muito Ter documentos como fotografias, relatórios de instituiçòes do governo, resultados de análises que tenham sido realizadas, materias de jornal, estudos de universidades, depoimentos de pessoas que sofrem com o problema, etc.
Com esses dados em mäos podemos: Compreender melhor o nosso problema; pensar nas açôes necessárias para a melhoria do problema, determinar quais são as ações mais urgentes. 


\section{APENDICE 03 - Roteiro para entrevistas com técnicos}

- Existem projetos específicos para o setor?

- Organograma da SEDEMA

- Gerenciamento e administração: responsáveis, atividades, critérios para cortes, projetos educativos, projetos de plantio, espécies, mapa, dados, histórico, etc

- Qual a opinião do técnico sobre a arborização atual?

- Diversificação de espécies.

- Arborização com frutíferas.

- Regras da CPFL

- Arborização com espécies de pequeno porte e arbustos.

- Calçadas verdes

- Podas

- Porque a população solicita os cortes?

- No campo educacional, o que poderia ser feito para melhorar o quadro?

- Legislação: Como funciona?

- Políticas públicas?

- Participação das universidades. 


\section{APÊNDICE 04 - Questionário aplicado nos e pelos grupos QUESTIONÁRIO / ENTREVISTA}

Idade: Sexo: Local de nascimento:

Há quanto tempo reside em Piracicaba: Bairro em que reside:

1) Qual a primeira palavra ou o primeiro sentimento que lhe vem à cabeça quando falamos de
borização de rua?

4) Assinale com um $X$ no (s) benefícios que as árvores de rua trazem aos moradores das cidades:

) Redução no consumo de energia com refrigeração dentro das casas

) Sombra para os pedestres e os carros

) As folhas da copa filtram a poeira do ar

) Redução da poluição sonora e visual

) Abrigo para os pássaros

) Reduçấo da velocidade dos ventos

) Valorização econômica das propriedades

) Melhoria das condições de saúde física e mental da população

Você tem árvore plantada na calçada em frente à sua casa?

i Se a resposta for "Sim", responda às seguintes questões:

1) Sabe dizer qual é o nome da espécie?

12) Sabe dizer qual é aproximadamente a sua idade, e quem a plantou?

3) Você e sua familia gostam de ter essa árvore em frente de casa ? Por quê ?

Se a resposta para a pergunta 3 for "não", responda:

51) Quais os motivos para que você não tenha?

2) Você e sua familia já tiveram alguma árvore ? Ela lhes trouxe problemas ? Quais ?

3) Você e sua família gostariam de ter uma árvore em frente de casa ? Se for sim, como gostaria ue fosse essa árvore ? ( com ou sem flores, com folhas grandes ou pequenas, com ou sem frutos pitangueira, jabuticabeira, sete-capotes, etc )

4) Tem alguma espécie de sua preferência? 


\section{APÊNDICE 05 - Convite distribuído ao grupo de $3^{\circ}$ idade}

\section{AO GRUPO UNIVERSIDADE ABERTA} A TERCEIRA IDADE

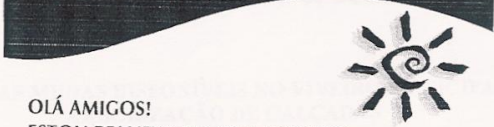

ESTOU REALIZANDO UMA PESQUISA

E PRECISO DE SUA OPINIÃO E EXPERIÊNCIA À RESPEITO DE UM TEMA LIGADO AO NOSSO MEIO AMBIENTE URBANO.

POR ISSO CONVIDO-OS PARA UMA REUNIĀO INFORMAL, DESCONTRAÍDA E PRAZEROSA. VENHA CONTRIBUIR COM SUA SABEDORIA; ELA É MUITO IMPORTANTE PARA QUE POSSAMOS CONSTRUIR UM MUNDO MELHOR.

ENG. AGRONNOMA ILZA MONICO.

DIA: $16 / 08 / 99$ DEPTO DE CIÊNCIAS FLORESTAIS

LOCAL: SALA 4 - DEPTO DE CIÊNCIAS FLORESTAIS HORA: $14 \mathrm{H} 30$

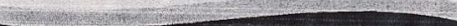 \\ PEÇO POR GENTILEZA CONFIRMAR A PRESENÇA COM SÔNIA / ASSIST ÊNCIA SOCIAL.}




\section{APÊNDICE 06 - Lista de espécies oferecidas pelo Viveiro Municipal}

\section{Prefeitura do Municipio de Piracicaba ESTADO DE SÃo PAULO - BRASIL}

Secretaria Municipal de Defesa do Meio Ambiente

\section{RELAÇÃO DAS MUDAS DISPONIVEIS NO VIVEIRO MUNICIPAL PARA ARBORIZAÇ̃̃O DE CALÇADAS}

\section{ESPÉCIE}

Canelinha

Cassia cinza

Chapéu de napoleão

Espirradeira branca

Espirradeira rosa

Espirradeira vermelha

Esquinus mole

Flamboyanzinho

Hibisco amarelo

Ipê amarelo (T.crysotricha)

Magnólia amarela

Manacá da serra

Monguba

Murta (saco peq.)

Murta (saco grande)

Oiti

Pitanga

Pitanga preta

Quaresmeira rosa

Quaresmeira roxa

Resedá branco

Resedá rosa

Resedá rosa

Resedá lilás

\section{ALTURA}

$2,20 \mathrm{~m}$

$2,20 \mathrm{~m}$

2,20 m

$0,90 \mathrm{~m}$

$0,90 \mathrm{~m}$

$0,90 \mathrm{~m}$

$0,60 \mathrm{~m}$

$1,40 \mathrm{~m}$

$1,50 \mathrm{~m}$

2,20 m

$1,70 \mathrm{~m}$

$1,50 \mathrm{~m}$

$1,40 \mathrm{~m}$

$1,30 \mathrm{~m}$

$1,20 \mathrm{~m}$

$1,20 \mathrm{~m}$

$0,70 \mathrm{~m}$

$0,70 \mathrm{~m}$

$2,00 \mathrm{~m}$

$2,00 \mathrm{~m}$

$2,00 \mathrm{~m}$

$2,00 \mathrm{~m}$

$1,20 \mathrm{~m}$

$1,80 \mathrm{~m}$
QUANTIDADE

1.720

200

1. 146

450

2.350

300

1.615

2.600

75

84

3.110

840

150

1.230

2.661

1.258

1.112

700

367

403

200

400

3.000

230 


\section{Projeto de arborização afetará meio ambiente}

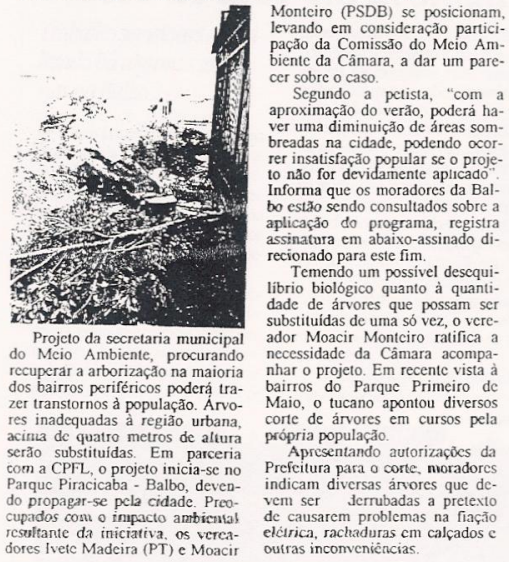


(49) 1 EIO AMBIENTE

Empresas solicitaram cortes de ipês em avenida

Trabalbo semelhanté realizado bá algumas semanas na Balbo

C inco árvores foram cortadas na avenida Cássio Paschoal Padova. ni, no bairro Santa Cecilia, pela Secretaria Municipal de Defesa do Meio Ambiente(Sedema). O corte foi justificado pelo secretário Toshio Icizuca por os ipês estarem atrapalhando a fiação elétrica.

Icizuca disse que o corte das árvores foi solicitado por empresas instaladas na regiâo, que também se comprometeram a fornecer as mudas para reposição dos ipês. Momadores da avenida ligaram ontem para a Central de
Atendimento ao Leitor - CAL - 0800 552555 do $J P$ reclamando do corte das árvores. Os moradores estâo preocupados. Eles querem saber se outras árvores serão plantadas no local.

Segundo o secretário Toshio Icizuca, da Sedema, o corte das árvores foi uma solicitação de empresas instaladas na regiầ, que também se comprometerami a fornecer as mudas para a reposiçào das árvores cortadas. O secretário disse que as árvore eram î̀ếs que estavam atrapalhando a fiação elétrica.

"A CPFL fezo rebaixamento da copa para podermos efetuar os cortes, mas novas ărvores, mais adequadas ao meio urbano, serão plantadas no local", garantiu.

No lugar das ipês, serâo plantadas murtas, canelinhas e espirradeiras.

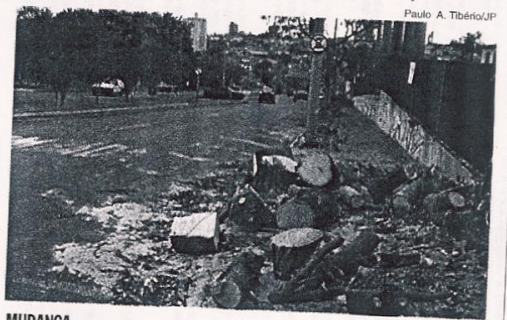

\section{MUDANCA}

Sedema fez o corte de cinco ipês na avenida Cássio Padovani, ontem 


\section{APÊNDICE 09 - Lei Municipal 3131}
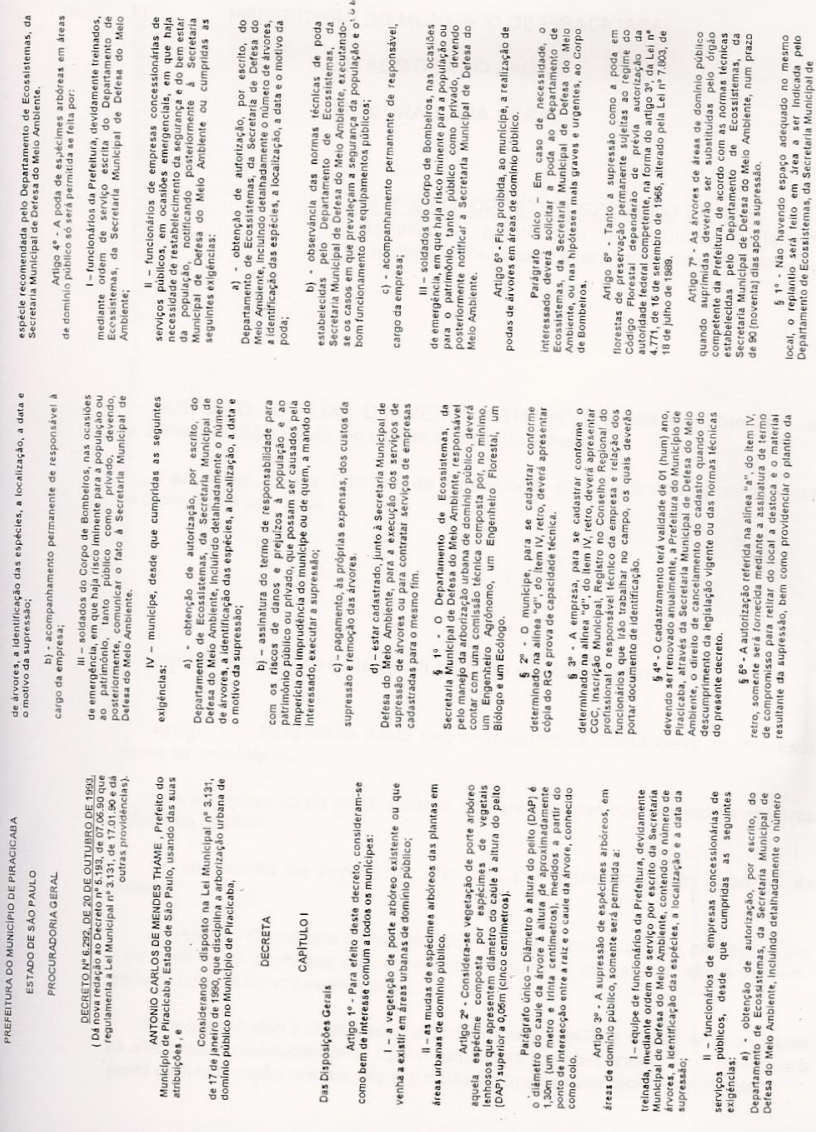


\title{
APÊNDICE 10 - Lei Municipal 4214/96
}

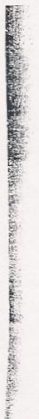

\author{
PREFEITURA DO MUNICIPIO DE PIRACICABA \\ ESTADO DE SÃO PAULO \\ PROCURADORIA GERAL
}

\begin{abstract}
LEI N 4.214 , DE 18 DE DEZEMBRO DE 1996. (Disciplina a arborização de domínio público Município de Piracicaba e dá outras providéncias)
\end{abstract}

ANTONIO CARLOS DE MENDES THAME, Prefeito do Municipio de Estado de São Paulo, no uso de suas atribuições.

Faz saber que a Camara de Vereadores de Piracicaba aprovou e el€ promulga a seguinte

\section{E I N $N^{\circ} 4 \begin{array}{llll}4 & 2 & 1 & 4\end{array}$}

Capítulo I - Da supressão e da poda de espécimes arbóreos

Artigo $1^{\circ}$ - Para efeito desta Lei, consideram-se como bens de interesse todos os municipes:

I - a vegetaçăo de porte arbóreo existente ou que venha a existir em área comínio público; público.

II - as mudas de especimes arbóreas plantadas em areas urbanas de

Artigo $2^{\circ}$ - Considera-se vegetaçăo de porte arbóreo aquela composta por R. ou espécimes lenhosos que apresentem diâmetro do caule à altura do peito perior a $0,05 \mathrm{~m}$ (cinco centimetros).

Parágrafo único - Diámetro à altura do peito (DAP) é o diâmetro do caule a altura de aproximadamente $1,30 \mathrm{~m}$ (um metro e trinta centimetros), medidos a ponto de interseç̧ăo entre a raiz e o caule da arvore, conhecido como colo. 
Artigo $3^{\circ}$ - A supressão de espécimes arbóreos em áreas de dominio ra permitido a:

I - equipe a serviço da Prefeitura, devidamente treinada, mediante ordem de escrito, assinada por técnico habilitado, do órgăo competente da Prefeitura

Piracicaba, incluindo detalhadamente o número de árvores, a identificaçāo ânes, a localização, a data e o motivo da supressão;

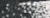

He II - funcionários de empresas concessionárias de serviço público, desde tas as seguintes exigencias:

-10

a) obtençăo de autorizaçăo, por escrito, do órgăo competente da Prefeitura Piracicaba, incluindo detalhadamente o número de árvores, a identificação , a localizaçăo, a data e o motivo da supressăo;

b) acompanhamento permanente de técnico habilitado responsável, a (5) interes

1.

III - soldados do Corpo de Bombeiros, nas ocasiões de emergência, em que iminente para a população ou ao patrimo̊nio, tanto público como privado, iposteriormente, comunicar o fato ao orgăo competente da Prefeitura Municipal terba;

sit

N - municipes, desde que cumpridas as seguintes exigéncias:

a) obtençăo de autorização, por escrito, do órgão competente da Prefeitura Municipal de Piracicaba, incluindo detalhadamente o número de árvores, a identificação das espécies, a localização, a data e o motivo da supressão:

b) assinatura de termo de responsabilidade para com os riscos de danos e prejuizos à populaçăo $\theta$ ao património público ou privado, que possam ser causados pela impericia ou imprudẻncia do municipe ou de quem a mando do interessado, executar a supressão;

c) pagamento, às próprias expensas, dos custos de supressão e remoção das ánores;

d) estar cadastrado junto ao órgăo competente da Prefeitura Municipal de Piracicaba, para execução de serviços de supressão de árvores ou, caso queira contratar serviços de empresas para o mesmo fim, estas deverăo, também, ser cadastradas perante aquele orgão.

§ $1^{\circ}$ - A autorização referida no inciso IV, retro, somente será fornecida a assinatura de termo de compromisso, no qual se compromete a efetuar a e a retirada do material resultante da supressão, bem como providenciar o de reposiçăo, conforme recomendação do órgão competente da Prefeitura the de Piracicaba, e nos termos do artigo $7^{\circ}$ da presente Lei. 
$\S 2^{\circ}$ - Somente poderão ser cadastrados junto ao órgão competente da Municipal, para execuçăo de serviços de supressåo de árvores, pessoas inélidicas que comprovarem habilitaçăo na área.

$\S 3^{\circ}$ - O interessado será comunicado do deferimento ou indeferimento do via postal, como aviso de recebimento - AR, no prazo de 60 (sessenta) dias.

\section{Atsis a}

Artigo $4^{\circ}$ - A poda de espécimes arborreos, em área de domínio público só

1 - funcionários à serviços da Prefeitura Municipal, devidamente treinados, ordem de serviço escrita do órgåo competente da Prefeitura Municipal de assinada por técnico habilitado na área;

II - funcionários de empresas concessionárias de serviços públicos, em emergências, em que haja necessidade de restabelecimento da segurança estar da população, notificando posteriormente o órgāo competente da Municipal de Piracicaba, ou cumpridas as seguintes exigências, se serviços

a) - obtenção de autorização, por escrito, do órgăo competente da Prefeitura Municipal de Piracicaba, incluindo detalhadamente o número de árvores, a identificaçăo das espécies, a localização, a data e o motivo da poda;

b) observåncia das normas técnicas de poda estabelecidas pelo orgāo competente da Prefeitura Municipal de Piracicaba, excetuando-se os casos em que prevaleçam a segurança da populaçăo e o bom funcionamento dos equipamentos públicos:

c) acompanhamento permanente de técnico responsável, habilitado na área, a cargo da emipresa.

III - Soldados do Corpo de Bombeiros, nas ocasiðes de emergência, em risco iminente para a população ou para o patrimônio, tanto público como devendo posteriormente notificar o órgăo competente da Prefeitura Municipal de b.

Parágrafo único - O interessado será comunicado do deferimento ou a) dias.
diado por via postal, com aviso de recebimento - AR, no prazo de 60 not

Artigo $5^{\circ}$ - Fica proibida, ao municipe, a realização de podas de árvores de domínio público.

Artigo $6^{\circ}$ - Tanto a supressăo como a poda em florestas de preservação te, sujeitas ao regime do Código Florestal, dependerá de prévia autorizaçăa 
atoridades federais e estaduais competentes, na forma do artigo $3^{\circ}$ da Lei $n^{\circ} 4.771$, 15 de setembro de 1965, alterado pela Lei $n^{\circ} 7.803$, de 18 de julho de 1989

Artigo $7^{\circ}$ - As árvores suprimidas em área de dominio público, em funçăo trata o artigo $3^{\circ}$, retro, nos seus incisos I, II e III, deverăo ser repostas num prazo 125 (quinze) dias, contados da data da supressão, constante no documento zutivo, atendendo as normas da presente Lei e as orientações do órgão - etente da Prefeitura Municipal de Piracicaba.

$\S 1^{\circ}$ - Năo havendo espaço adequado no mesmo local, o replantio será feito a ser indicada pelo órgão competente da Prefeitura Municipal de Piracicaba, de dion a manter a densidade arborea no Municipio.

$\S 2^{\circ}$ - A supress åo solicitada pelo munlcipe, quando realizada por equipe a no da Prefeitura Municipal ou a seu mando, deverá ter seu custo de reposição pago t municipe, bem como os custos da supressão, de acordo com a regulamentação Lei.

$\S 3^{\circ}$ - Excetuami-se do disposto no parágrafo anterior, os casos justificáveis comprometimento da estrutura de residências, da segurança de cidadăos ou de saúde pública.

Artigo $8^{\circ}$ - O municipe que efetuar plantio de espécimes arbóreos em sordo com o disposto nesta Lei e das normas técnicas do órgāo competente da 2ura Municipal de Piracicaba, será notificado pelo referido órgão, a efetuar as alteraçōes.

\section{Capítulo II - Dos critérios de arborização}

Artigo $9^{\circ}$ - A arborizaçăo das areas de dominio público urbanas do aro a partir da publicaça da presente Lei, obedecerá os seguintes criterios:

1 - nas ruas com largura igual ou superior a 14 (quatorze) metros, será * do plantio de espécies de porte pequeno nas calçadas que dão suporte à recie Thergia elétrica, enquanto que, nas calçadas opostas. poderăo ser plantadas es de porte médio;

If - nas ruas com largura inferior a 14 (quatorze) metros, somente será o plantio de espécies de porte pequeno;

III - nas avenidas, com canteiro central, somente será permitido o plantio - pectivos canteiros, de espécies arbcreas do tipc colunares ou palmares de estione quando estes canteiros possuirem larguras inferiores a $3.5 \mathrm{~m}$ (trẻs metros e 
centimetros), nåo devendo a largura da massa arbórea ultrapassar a largi 4hareses civo canteiro.

ariete

IV - nas avenidas, cujo canteiro central tenha largura igual ou superior a 3 - Jetros e cinqulenta centímetros) poderăo ser plantadas árvores de pequen - grande porte, desde que a largura de suas massas năo ultrapassem a largu divo canteiro até uma altura minima de $5,5 \mathrm{~m}$ (cinco metros e cinquien teros);

$V$ - nas calçadas laterais de avenidas com canteiro central, apenas ser gata

o plantio de espécies arbóreas de pequeno porte:

VI - o espaçamento entre árvores, determinado pela municipalidade, se: 3rimo, 08 (oito) metros, devendo ser respeitado o afastamento de 5 (cinco masuinas e com relação aos postes;

가난 VII - as mudas de árvores serão fornecidas e plantadas pela Prefeiturá
axla através de seu órgăo competente, podendo o municipe efetuar, às expensas axpén árvores em áreas de domínio público, junto à sua residência ou terreno, desde * whervadas as exigências desta lei e normas técnicas elaboradas pelo órgã +..tinte da Prefeitura Municipal de Piracicaba:

VIII - as calçadas, que circulem praças, devem ficar isentas de arborizaçăo; IX - o órgåo competente da Prefeitura Municipal de Piracicaba indicará as
de porte pequeno. medio e grande a serem plantadas nos respectivos locais -erencia para espécies nativas de ocorrencia local;

$i^{2}$

X - as árvores já plantadas nas áreas de domínio público, no perímetro 4ue se mostrem inadequadas ao paisagismo, ao bem estar público e ao bom mento dos equipamentos públicos, serão paulatinamente substituidas pela yesha Municipal, sem onus para os municipes, por outras mais adequadas aos mos locais

Artigo 10 - Os projetos de instalaçăo de equipamentos públicos res em áreas de dominio público já arborizadas deverão compatibilizar-se com a

Ao arbórea existente, de modo a evitar futuras podas

\section{Capitulo IV - Das infraçōes e penalidades}

Artigo 11 - Além das penalidades previstas no artigo 26 da Lei Federal n 15 de setembro de 1965, aiterada pela Lei $n^{\circ} 7.803$, de 18 de julho de 1989 , e 


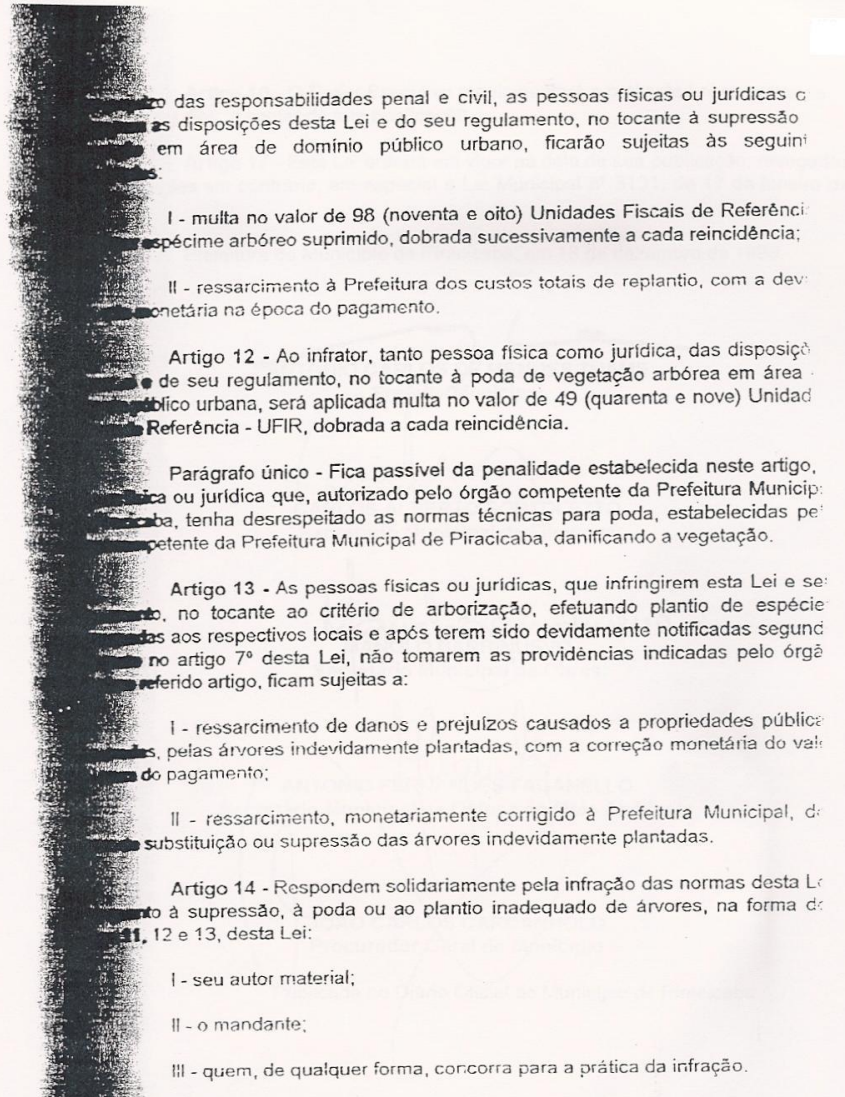

Artigo 15 - Se a infraçăo for cometida, por servidor municipal, em serviç 4.t. de será determinada após a instauração de processo administrativo, na form: restura em vigor. 


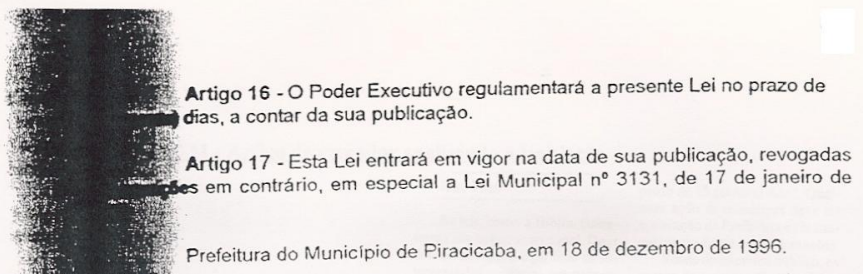

Artigo 16 - O Poder Executivo regulamentará a presente Lei no prazo de dias, a contar da sua publicação.

Artigo 17 - Esta Lei entrará em vigor na data de sua publicaçåo, revogadas
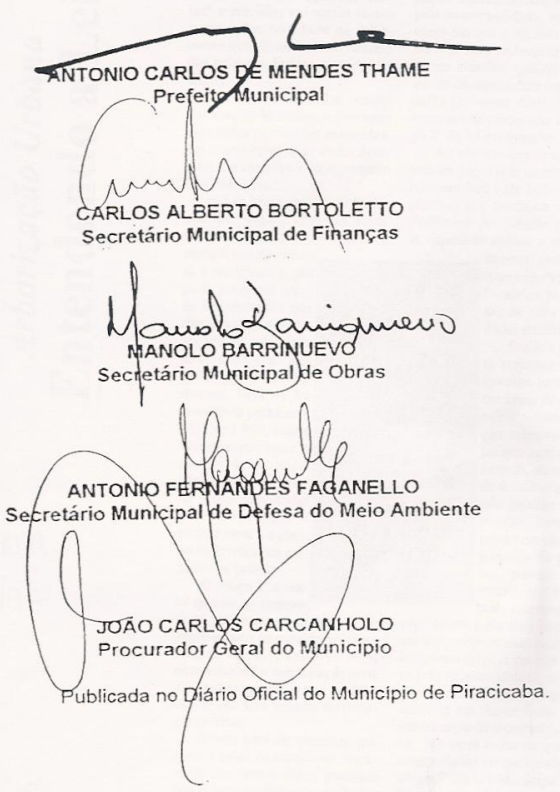


\section{APÊNDICE 11 - Artigo de vereador analisando a legislacão}
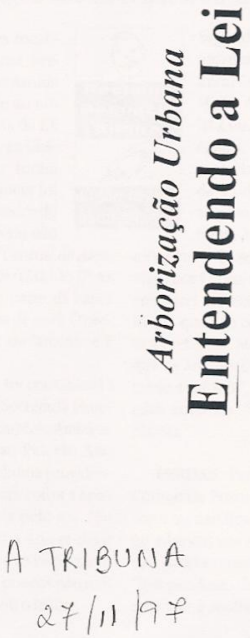
distorçōes podem ser esperadas. tio de árvores nas cal-
João Pauli

As leis, como a Biblia, fisica. mente são palavras no papel. Deus deu ao homem a lib̨erdade de interpretá-las conforme sua própria consciência. Assim, guerras "santas" e suicidios cm massa foram promovidos com base no julgamento que alguns homens fizeram das palavras divinas, contidas na Biblia

No que se refere à Lei, escrito. por simples humanos, muito mais dai a importância do Poder Judiciàrio, a ele cabe a interpretaçầo final das Leis.

A Lei Municipal n" 42/4/96, que disciplina a arborização de dominio público de Piracicaba é razoavelmente extensa e complexa, o que pode justificar erros de interpretação que têm causado grandes prejuizo à qualidade de vida, mais sentidos reste periodo de calor intenso. Esta lci foi antocedida pela Lei ${ }^{\circ}$ 3131 de 1.990, ambas visam disciplinar o manejo da arborizacão urbana, atribuindo responsabilidades e critérios para a poda, o corte e o plancadas da cidade.

0 artigo $1^{\circ}$ é cla ro quanto ao responsável pela manutençâo da arborizaçào urbana a considerar "como bens de interesse comum a todos os municipes" a vegetação de porte arbóreo existente ou que venha a existir em área urbana de dominio pủblico.

Sendo bem de interesse comum a todos os municipes, tratase de um bem publico, portanto sob a responsabilidade do Poder Público, o qual tem o dever de executar todas as açōes necessárias para a sua conservação e melhoria

E, portanto, da Prefeitura a competência e a obrigaçâo de podar, cortar, plantar e replantar árvores, em substituição a outras retiradas de nossas calçadas, conforme 0 artigo 70 . "As arvores suprimidas em área de dominio público ... deverão ser repostas num prazo de 15 (quinze) dias". Qualquer ação de municipes deve ter aprovação da Prefeitura e ser executada mediante suas orientaçōes

Sendo do interesse público, os custos de manutenção da arborização urbana devem ser pagos pela municipalidade, exceto nos casos $\mathrm{cm}$ que a retirada de árvo. res seja em atendimento a pedido de um cidadão. quando entäo 05 custos de supressão e replantio ficarão por conta deste, conforme expresso no porágrado $2^{\circ}$ do artigo $7^{\circ}$ da lei em questão.

Ao afinnat que os custos devem ser pagos pelo municipe, a Lei não transfere a cle a obrigaçìo de plantar. que continua sendo da Prefeitura. Ao cidadào requerente imputa-se apenas a obrigaçâo
É, portanto. da Prefeltura a competéncia e obrigaçũo de podar, cortar, planiar e replantar árvores, em substituiçáo a outras retiradas de nossas calçalas, conforme 0 artigo $7^{\circ}$ : de pagar por acóes da municipalidade necessárias para atender às suas necessidades particulares

Sendo a prefeitura responsável pelas árvores localizadas em áreas de dominio público, ć sua obrigaçào substituir aquelas que estejam danificando, ou ameaçando danificar patrimômio público ou particular, bem como pondo em risco a segurança de populares, nestes casos, qualquer cidadão pode requerer o serviço (corte e plantio) $5 \mathrm{~cm}$ precisar arcar com os seus custos, visto que o serviço ja deveria ser feito pela municipalidade, sob pena de responsabilidade por qualquer acidente em decorrência de má conservação de arborização pública. Sâo estes casos os que cstão resguardados no parágrafo $3^{\circ}$ do artigo $7^{\circ}$ da Lei Municipal 2414/ 96. que em nenhum momento abre exceção ao dever de a Prefcitura substituir árvores retiradas.

Esperamos que os responsáveis pela arborização pública reavaliem o seu entendimento da Lei que a disciplina em nosso Município, dando maior atençào à necessidade de plantar e repantar árvoes $\mathrm{em}$ nossas calçadas. 


\section{árvore \\ Árvores são mortas na Chácara Nazareth}

\section{Morador alegou não saber quem é o autor do dano às duas árvores, ocorrido enquanto ele viajava}

D uas ârvores locali zadas na rua Fernando Ferraz de Arruda Pinto, em frente ao número 2.152, atrás da EE Dr. Jorge Coury, na Chácara Nazareth, foram mortas. A denúncia foi feita por um morador do bairro, que preferiu não

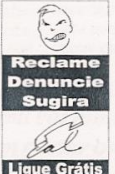

$0800-552555$
Segundo o professor universitário de Bioquí mica, Geraldo Claret de Mello Ayres, morador hâ 23 anos noendereço citado, ao voltar de uma viagem, há cerca de 15 dias, encontrou as duas árvores em frente à sua casa já dase identificar, à Central de Atendimento ao leitor (CAL) do JP. As árvores tiveram parté da casca cortada em forma de anel. O processo chama-se anelamento e é irreversivel.

O problema foi comunicado pelo morador à Secretaria Municipal de Defesa do Meio Ambiente (Sedema) e ao Pelotào Ambiental, mas nenhuma providência foi tomada para coibir a açào dos responsáveis pelo ato. "Se precisa derrubar a árvore deve haver algum motivo justificável, mas matá-la aos poucos nâo tem sentido", reclamou o leitor. nificadas. "Nào sei quem fez isso, viajei por 11 dias e quando voltei encontrei-as assim", disse o professor, que nāo comunicou o fato à Prefeitura. Mello Ayres disse que as árvores estavam "levantando a calçada", mas nào pediu para cortá-las. "Eu mesmo as plantei."

PERDAS - Pelo artigo 120 do Código de Posturas, é proibido corte ou danificação de árvores ou arbustos nas ruas, logradouros, jardins e parques públicos. "Independente da justificativa, é aplicada a multa de R\$271,10

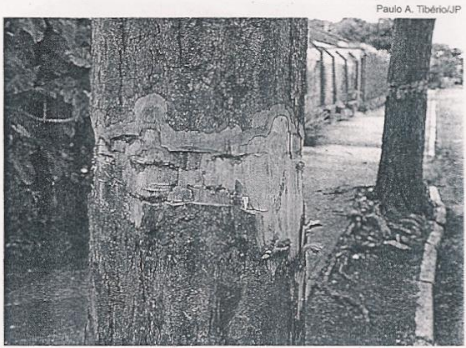

MORTE

As árvores tiveram parte da casca cortada em forma de anel

(254,7785 Ufirs) ao morador da casa para cada árvore danificada", salientou José Antônio Mendes de Matos, subinspetor do Pelotào Ambiental, que foi ao local e autuou o proprietário da residência.

Matos explicou que somente este mês, o Pelotão Ambiental fez 12 autuações pelo mesmo motivo. "Em todos os casos as pessoas alegam que não foram elas, que estavam viajando ou que nào sabiam do problema." A Prefeitura faz a retirada da árvore e o morador é notificado a plantar outra em prazo a ser determinado.

\section{Ambientalista considera árvores fundamentais}

De acordo com o engenheiro agrônomo José Otávio Machado Menten, o anelamento ocorre quando é feito um corte longitudinal, tirando um anel da casca da árvore, impedindo que a seiva bruta (nutrientes que vêm do solo) suba e a seiva elaborada desça pelos vasos que estão na casca, deixando de alimentar a raiz da planta. "Este problema nào tem soluçào, a árvore está fadada à morte", lamenta.
Segundo o ambientalista Juan Sebastianes, as árvores têm importância fundamental à vida do ser humano. "Elas têm a funcão de baixar a temperatura do ambiente na casa dos quatro ou cinco graus, além de auméntar a umidade relativa do ar, importante, principalmente, em épocas de estiagem, quando as vias respiratórias sofrem ressecamento." Além disso, a sombra das árvoresé fresca, diferente da sombra dos edificios, o que é fa- cilmente perceptivel em passeios a áreas bem arborizadas, como bosques.

As árvores também são abafadoras de ruídos e têm a capacidade de filtrar os gases poluentes ou as particulas sólidas (poeira). "Quando chove e sentimos cheiro de terra, é a terra depositada sobre as folhas das árvores que cai com a chuva" explica Sebastianes

"O ser humano necessita da presenca de outros seres vivos. as árvores tornam o ambiente mais agradável, comprovadamente ajudam a diminuir o estresse, aumentando o prazer de viver das pessoas por proporcionar uma paisagem bonita" lembrou o ambientalista.

"A árvore é tão importante. que, se estiver incomodando, é necessário que um técnico faça a avaliação, mas se a pessoa toma a atitude de matá-la, do meu ponto de vista, é crime ambiental", disse Menten. 


\section{APÊNDICE 13 - Jornal de Piracicaba 02/04/2000 - Denúncia sobre cortes Mais um crime ambiental na cidade}

Em Piracicaba, o pequeno número de árores existentes nas ruas sofre com a ação criminosa de algumas pessoas

A

pesar da escassez de árvores Ana cidade, alguns piracicabanos vêm contribuindo para a redução desse número, em atos que constituem crimes ambientais e falta de respeito aos demais seres vivos Na semana passada, a Secretaria Municipal de Defesa do Meio Ambiente (Sedema) e a Companhia Paulista de Força e Luz (CPFL),

realizaram o corte de uma árvore da espécie "Angico", madeira de lei, com cerca de 40 anos de idade e 18 metros de altura, localizada à rua Francisco José Machado, defronte ao número 461, no Jardim Brasilia. A árvore havia sido "anelada", processo que impede a subida da seiva para as folhas, secando a planta e provocando sua morte.
Em matêria publicada em 28 de janeiro deste ano, o Jornal de Piracicaba noticiou o "assassinato" de outras duas árvores na Chácara Nazareth, porém, como dessa vez,

Sedema vai punir
quem cortar ou
provocar a morte
de árvores
o criminoso nào foi identificado. O anelamento é crime ambiental e as pessoas que infringirem a lei, além de sofrerem as penalidades da Lei Federal, podem ser multadas em 254,7788 Ufirs (R\$ 271,11) e ressarcimento à Prefeitura dos custos totais do replantio, com correçâo monetária. A multa é prevista pelo artigo 120 da Lei 2433/81, do Código de Posturas do município.

A Sedema está fazendo um levantamento de quantas árvores condenadas existem no município, para elaboração de documen-

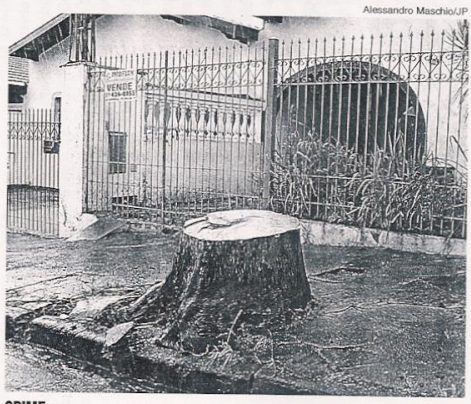

CRIME

Arvore, de cerca de 40 anos, foi cortada no Jardim Brasitia

tação fotográfica, que será encami- responsáveis e acabar com esse nhada às providências da Promo- crime ambiental", disse Henrique toria. "Nossa finalidade é punir os Barbin, assessor da Secretaria.

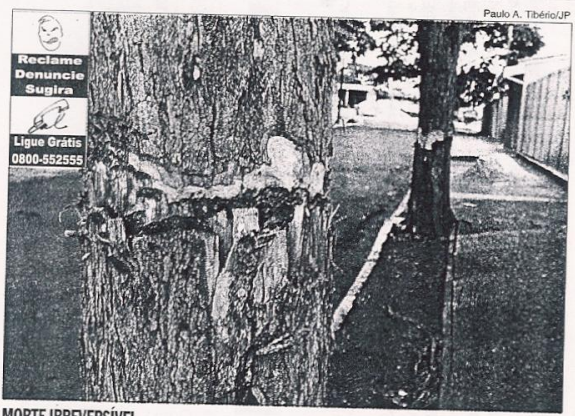

MORTE IRREVERSIVEL

Uma das árvores que sofreu o processo por anelamento no Castelinho
Árvores estão sendo mortas por moradores

A morte de árvores por anelamento (corte na casca) tem sido uma prática utilizada por moradores, para conseguirautorizaçào de corte da Prefeitura. Somente neste mês, o Pelotão Ambiental fez 12 autuações por este tipo de ação. Um morador do bairro Castelinho ligou para a $C A L$ do $J P$ para denunciar o "assassinato" de duas árvores. 


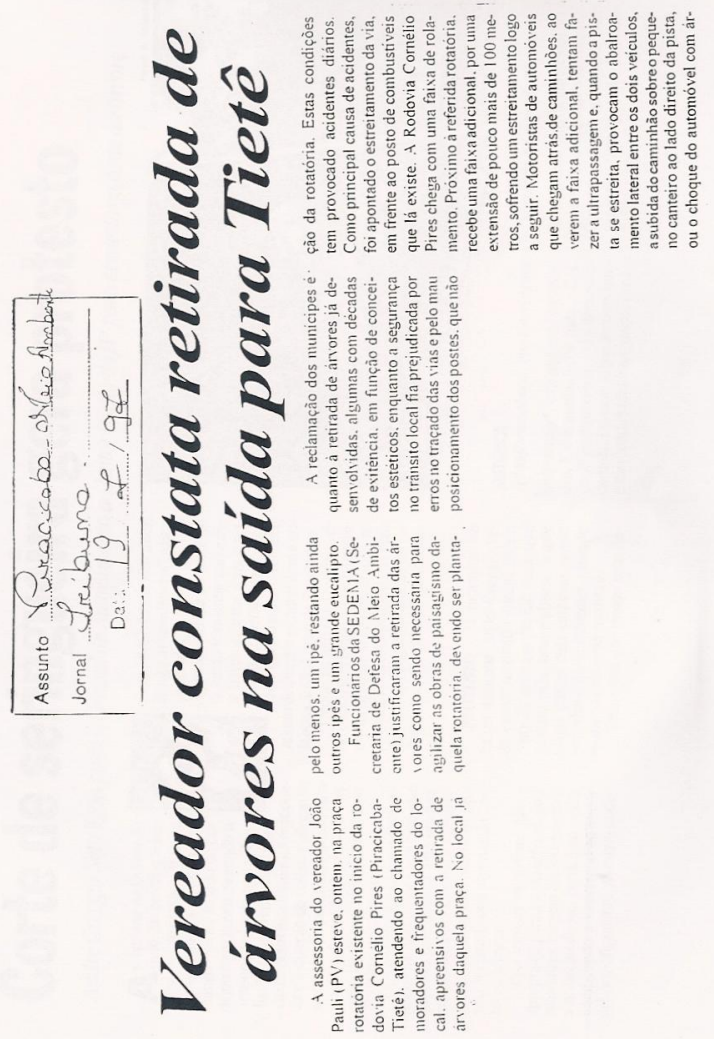


APÊNDICE 15 - Jornal de Piracicaba 22/07/98 - protesto contra corte de árvore antiga

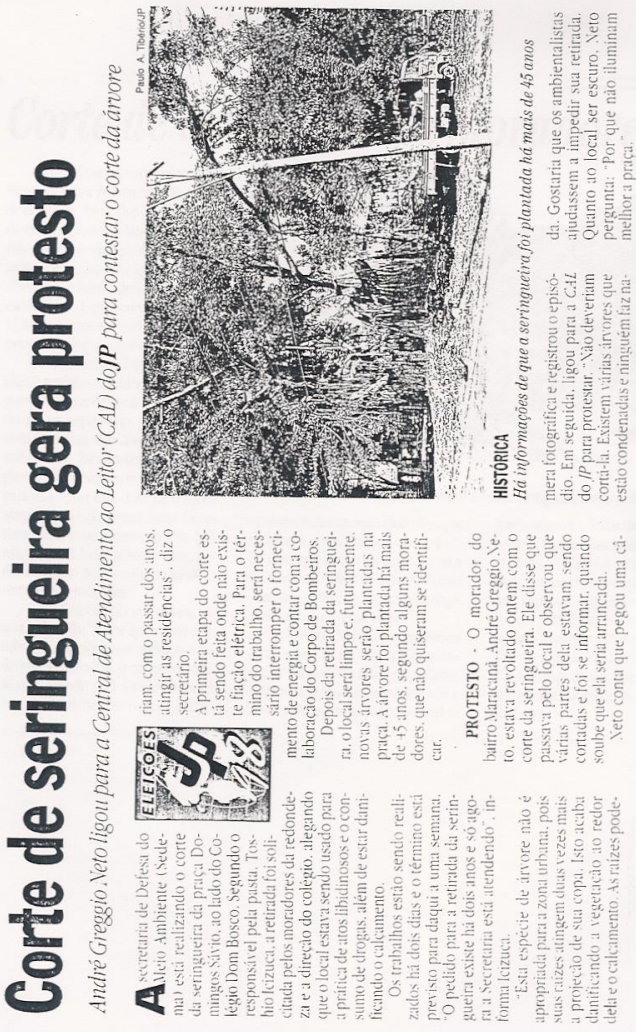




\section{APÊNDICE 16 - Jornal de Piracicaba .... - reclamacão de moradores}

\section{Corte de árvores irrita moradores}

0 conte de seis árvores na rua joào Sampaio, altura do número 500 , na tarde de ontem, foi motivo de reclamação de vários moradores. Mas, há divergên. cias quanto ao número de plantas cortadas. Alexandre Salia ligou para o JP dizendo que funcionários da Prefeitura estiveram no local e cortaram cerca de 13 árvores grandes e antigas, plantadas pelas pessoas que moram naquela rua.

Outra reclamante foi Fernanda Marchetti, também moradora na rua, que questionou o corte das árwores: "Entendo que os responsáveis pelo corte deveriam avisar os moradores sobre o porquê do corte. Eles disseram que vào replantar, mas deveriam marcar uma data para isso. A rua está cheia de buracos atrapalhando todosos motoristas. Deveriam deixar essas árvores do jeito que estavam; o dinheiro gasto no corte, poderiam usá-lo no conserto do asfalto", completou a moradora.

Cintia Fonseca Ribeiro também estava indignada: "Soube que, como contribuinte, a pessoz que pediu o conte deveria ser atendida, o que aconteceu. Só que, quando pedi uma lombada na rua, na Secretaria Municipal de Trânsi-

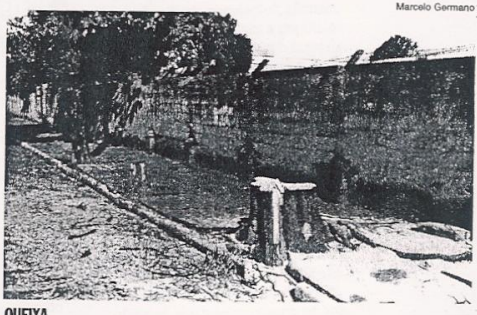

\section{QUEXXA}

Além de estarem "doentes", árvores estavam prejudicando o calsamento

to, ninguémdeuatencio Quer dizerque atendem a um pedido e a outro não?" Ela disse que entrou em contato com a Secretaria de Defesa do Meio Ambiente - Sedema, pedindo a presenca da engenheira responsável pelo corte.

Lidia d'Arce Martins, engenheira do setor Centro, foi até o local e informou que sete árvores deveriam ser cortadas. "Algumas sibipirunas, espatódease bau. hínias apresentavam estado securitário comprometedor. Todas tinham parte da copasecae causavam problemas nocalcamento. 0 corte foi autorizado, tamhém, porque as árvores estavam doentes", explicou. Segundo ela, o pedido foi feito pelo delegado de Ensino de Pi. racicaba, já que 05 galhos estavam caindo e, próximo ao local, há duas escolas. "Os galhos poderiam provocar graves acidentes se caissem sobre as crianças". justificou. 


\section{APÊNDICE 17 - Jornal de Piracicaba 01/08/97 - avaliacão de político do Partido $\underline{\text { Verde }}$ Falta verde na vida dos}

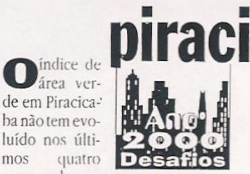

anos, colocan-

do a cidade en risco de entraro ano 2000 em situač̃o ainda mais crítica em termos de qualidade de vida. A opiniào é do ex-vereador e um dos fundadores do Partido Verde na cidade, o engenheiro agrônomo e professor Juan Antonio Moreno Sebastianes, com base na quantia de metro quadrado para cada habitante instituida pela Organizaçào das Naçòes Unidas (ONU), necessária para garantir ao cidadào uma vida saudável.

"A qualidade tem se deteriorado", revela o ex-vereador, af irmando que a convencio de Estoculmo, realizada em 1972, determinutu cono indice de area verde por hal sitinte. 12 metros quadratos. Piracicaba oferece para cadia morador pesuco mais de um quarto do determinado: 3.7 metros quadrados de área verde. Selatatianes e o presictenie do PV Marco Taniguchi afirmam que essa situaçao é consequência de má distribuiçio de äreas.

Eles revelam yue há hairros em que nàn existe nada cm termos de area verde. $\mathrm{Lm}$ excmplo disso, segundo Selvastianes, $\dot{e}$ o Batro dos Alemães, Como opcìo, os moradores desse local se dirigem it Fscola Superior de Agricultura Luiz de Queiroz (ESALQ USP) ou à Rua do Portes para ter um pouco de lazer econtato com o verde.

Segundo eles. em algumas regiñes de Piracicaba existem al guns espaços, denominades parreute de vjzinhanci. gue poderiam ser aprowcitados e urilizados pela comunidade como uma área verde. f́. o caso da pracinha cm frente as (colégio D) Bosco-Assuncàno, nal rua Gomes Carneiro, área central da cidade, e o jardim no entorno da lgreja des Bom Je-

\section{cabanos}

sus, no Bairro Alıo, "Mas estão degradados e a falta de segurança fazem com que fiquem abandonados, sem uso da própria populaçâo", afirmam.

Schastianes destaca a importância das áreals verdes para o lazer da populaçào, melhoria da qualidade do ar que se respira, aumento da umidade do ar na época de estiagem e para manter a fauna. "A arborização tira a poluiçàn do ar, nào apenas os componentes gasosos, mas também os sólidos e funciona como abafädor de ruidos", observa.

ARBORIZAÇÃo - Taniguchi e Sehastianes contam que Piracicaba, na questào de arborização de rua, $t \mathrm{~cm}$ regredido em termos de quantidade. A situacçâo preocupa os ambrientalistas. segundo eles, tem-se cortado muitas árvores, mas nào se tem feito a substituiçào na mesma proporcầo, oque consideram pior do que cortar as que estão apresentando

prohlemas ou inadequadas, avisando que a lei de arborização não está sẹndo cumprida. Esta questão já foi até motivo de pedido de inquérito no $\mathrm{Mi}$ nistério Público.

Uma das ruas que recebeu uma amostra de reeducação de artorização na cidade foi a Tiradentes. "Mas ficou apenas na amostra, quando o trabalho adequado que se implantira naquela rua deveria ser espalhado por toda a cidade", relata. Como forma de ajudar a recuperar a arborizaçà), a prefeitura poderia utilizar mudas do próprio viveiro municipal, formado no Loteamento Santa Rita.

Para os integrantes do Partido Vercle, a situacào chegou a este ponto devido à falta do desenvolvimento de um trabalho de educação ambiental. Para revertero quadro, eles apontam a necessidade de conscientização da população sobre a importância da árvore para cada um, para poder cobrar a methoria na arhorizaçâo 


\section{APÊNDICE 18 - Jornal de Piracicaba 07/09/98 - "A resposta da Natureza"}

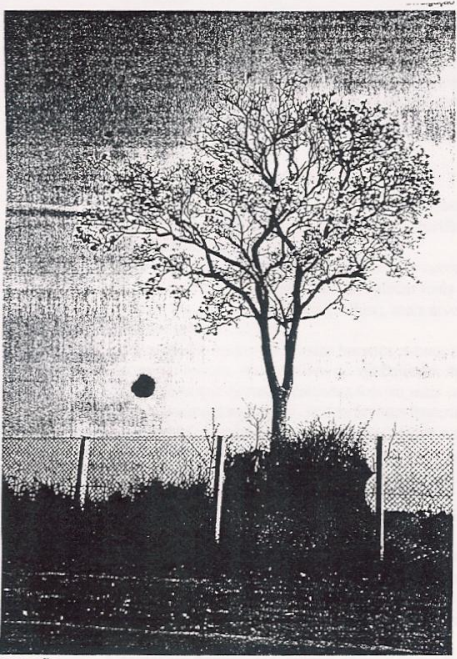

GRESSÃO

pê-amarelo sobrevive em um "torräo" de terra

\section{A resposta da natureza}

\section{Epaminondas S. B. Ferraz}

4

fúria do homem em agredir natureza é cada dia maior. A ganância e a ignorância andam de mãos dadas. Nào percebe o animal - sim, nào nos esqueçamos que somos também animais e que nem todos sâo ra. cionais, como se pensa - o preda. dor homem, que ele está desenfreadamente destruindo o seu precioso legado, seu único patrimônio. Vejam o estado em que se encontram os nossos rios, as nossas matas e 0 ar que respiramos.

Mass a nătureza é muito fortē e quando alguém faz alguma coisa em seu favor ela reage imediatamente e mostra o seu vigor. Aí está o exemplo do ribeirão Piracicamirim, a cloaca de 60.000 pessoas que do dia para noite. com a entrada em funcionamento da Estaçào de Tratamento de Esgotos, volta a ter peixes e começa a ser repovoado pela fauna e flora tipicas.

Vendo tudo isso, eu que tive o privilégio de conhecer o rio $\mathrm{Pi}$ racicaba paraíso dos pescadores, com suas águas limpas e suas margens cohertas de árvores nativas, começo a pensar com meus botòes: que ser sublime é esse que habita a natureza, dono de todas as virtudes, que no mesmo instante perdoa e retribui com benesses às mais sórdidas agressòes?

Gosto de observar tudo o que se passa ao meu redore, embora calejado, às vezes me surpreendo. Desde algum tempo tenho utilizado de um caminho, em plena zona urbana da cidade, onde existe uma extensa área acidentada, com algumas árvores, que o bicho-homem está aterrando, para satisfazer sua voracidade imobiliária. Com máquinas poderosas destruíram uma elevação e retiraram uma espessa camada de solo, 3 ou 4 metros, para enterrar toneladas de lixo que foram jogadas no fundo do pequeno vale, onde antes nascia um fio d'água. $\mathrm{Sa}$ bendo que a lei nào thes permite derrubar árvores, usaram de um artificio muito comum nos nosšos dias: deixar em torno da áivore um "torrâo" de terra com pouco mais de un metro de diâmetro. $\mathrm{O}$ artificio é simples, embora sórdido: não cortam a árvore, conforme a lei determina e ficam à espera de que ela morra de "morte natural", para completar a obra.

Já faz alguns anos que eu passo periodicamente pelo lecal e me compadeço com a cena dantesca vendo aquelas árvores que pouco a pouco vão se definhando. Outro dia, porém, a minha surpresa foi maior. Num mis. to de alegria e tristeza lá estava uma delas, um ipê-amarelo. completamente florido. Era a resposta da natureza. A árvore tinha que cumprir com o seu destino, nào podia deixar de florir na primavera.

Tal qual um condenado a morte, do alto do seu cadafalso. o ipê perdoava os seus algozes, retribuindo com flores a maldade dos homens 


\title{
APÊNDICE 19 - Tabulação de Respostas da "Oficina de Futuro"
}

\author{
Árvore da Esperança
}

Pergunta 1: "Como você gostaria que fosse a rua/bairro em que mora?"

Respostas : (*) ao transcrever as respostas procurei manter a fidelidade na forma e linguagem com que foram escritas, inclusive com os erros de grafia e vocabulário.

\section{Grupo de jovens - 24 participantes}

1-Gostaria que todos os carros a díesel que passassem por ela tivessem catalisadores;

Gostaria que cada setor da cidade (centro, periferia, etc.) tivessem um centro de reciclagem com acesso aos indivíduos;

Que cada morador mantesse a manutenção necessária em sua calçada, rua, bairro.

2-Menos violência, menos buraco, colocar mais árvores, retirar o lixo das ruas.

Menos buraco, menos fofoca (velhas), mais árvores, menos poluição sonora, menos vandalismo, mais policiamento, mais lazer.

3-Em minha rua/bairro: menos buracos, menos velhas fofoqueiras, mais árvores e arbustos, menos poluição sonora, menor índice de vandalismo, mais policiamento, mais lazer e recreação.

4-Gostaria que as ruas e calçadas fossem mais conservadas, que houvessem lixeiras nas ruas, mais policiamento e segurança, que as árvores fossem mais bem cuidadas.

5-Recapear as ruas paralelas à minha (porque a minha está recapeada, pois o prefeito mora nela), bastante árvores, menos violência, terminar o edifício da Encol.

6-Que os moradores não joguem lixo na própria rua, que todos conservem telefone públicos, iluminação pública, pois tudo isso é muito importante

7-Rua: gostaria que os vizinhos fossem mais unidos. Bairro: Um centro comunitário com campo e quadra esportivas para recreações, mais policiamento.

8-Combater a fome, menos violência, menos buracos, retirar o lixo das ruas.

9-Todos tenham uma vida digna. Que possam ter educação, saúde, menos violência, amor e paz.

10-Sem lixos jogados na rua, sem buracos, mais árvores, mais flores, sem poluição dos automóveis, etc.

11-Recapear a minha rua e o meu bairro, colocar mais árvores nas ruas, menos poluição, mais pássaros, menos violência.

12-Menos buraco, mais árvores, menos poluição, menos violência, mais policiamento.

13-Que as pessoas fossem mais amigas umas das outras.

14-Menos buracos, mais árvores, sem lixo na rua.

15-Em cada rua/bairro deveria ter latões onde fossem colocados o que é possível ser reciclado: papéis, vidros, plásticos, jornais...

16-Menos buraco, menos velha fofoqueira, mais árvores e arbustos, menos poluição sonora, menor número de vandalismo, mais policiamento, mais lazer.

17-Gostaria que todos fossem amigos de todos, gostaria que tivesse menos lixo nos terrenos baldios (isso traz mal cheiro).

18-Gostaria que tivesse rios limpos e sem esgotos, mais árvores, mais flores, mais pássaros, mais vida, menos poluição (lixo, esgotos, etc); gostaria também que o povo fosse mais consciente e não poluisse tanto o meio ambiente)

19-Que todos no meu bairro fossem todos amigos de todos, menos lixo nos terrenos baldios (isso traz mal cheiro), alegria, menos fofoca.

21-Gostaria que lá na avenida onde eu moro não tivesse muita poluição sonora, como sempre teve; e também a poluição de lixo também, queria que fosse um lugar tranquilo.

22-Gostaria que as ruas fossem "trafegáveis, o rio que corta o bairro não fosse tão "insuportável", as pessoas se conscientizassem de que existe lixos por toda parte que devem ser utilizados e que todos entendessem que só depende de nós. 
23-Gostaria que todos os carros a diesel colocassem catalizador, que todas as pessoas não jogassem papel ou qualquer objeto no chão, todas as pessoas de todas as casas separassem seu lixo para reciclar, pessoas lutassem para conservar o mundo.

24-Que não joguem lixo nas ruas, mais árvores.

\section{Grupo de terceira idade - 07 participantes}

1 -Gostaria que tivesse mais árvores na minha rua e também no meu bairro. Gostaria de poder tirar as grades das casas e as pessoas pudessem sair na calçada e conversar com seus vizinhos. Gostaria de poder ver e brincar com as crianças nas calçadas.

2 -Educação, União, Participação, Interação, Conscientização, Importância do agir individual.

3 -Conscientização do ser humano; propostas as nossas autoridades competentes; que nossa rua e vizinhança colaborass em; gostaria que nossa rua fosse um jardim; Mas vamos lutar para que nossos sonhos tornassem realidade.

4-Gostaria que minha rua fosse mais limpa, como no jogar lixo no chão, cachorro não sujar na calçada. Buracos na rua. Enfim, além da prefeitura cuidar melhor da rua e os moradores também. Meu bairro deve ser, isto é, a prefeitura cuidar melhor. Há bastante árvores bonitas, mas também muitas árvores doentes, secas, etc. As praças deviam ter guardas para que vândalos nào destruíssem. Educar melhor o povo.

5 -Gostaria que a rua não só a minha, mas todas as ruas, principalmente um planejamento do escoamento da água pluvial e outros planejamentos, só assim poderia ser uma boa rua, seria uma boa obra.

6 -Desenho de muitas pessoas em círculo em volta da rua.

7 -Minha rua acho ela ótima. Havia alguns problemas e já estão sendo resolvidos. O bairro acho muito barulhento, principalmente Sábado e Domingo. Gostaria que fosse mais silenciosa.

\section{Pergunta 2 " Como você gostaria que fosse a arborização de sua rua/bairro?"}

\section{Respostas Grupo de Jovens:}

1- Mais árvores.

2- Muitas árvores.

3- Mais árvores e flores.

4- Bastante árvores.

5- Muito arborizada , muitas sombras, menos calor no verão, tornaria a rua mais bonita, árvores frutíferas.

6- Praças com árvores frutíferas.

7- Lei para que seja plantadas no mínimo a cada dez metros, desta forma formando um ambiente saudável

8- Repleta de árvores.

9- Repleta de árvores.

10- Uma rua cheia de verdes, flores, coloridos... e tudo bem cuidado.

11 - Gostaria que fosse praticamente uma floresta.

12- Queria um pé de ovo frito ou cozido, um pé de melancia, pé de cebolinha, pé de milho.

13- Árvores altas e com copa grande, árvores frutíferas, nas avenidas ipês amarelos, rosas e brancos.

14- Com árvores frutíferas (frutas pequenas), proporção 1 casa 1 árvore, ipês (beleza), árvores com copa grande (sombra).

15- Com árvores frutíferas que dessem frutos pequenos, ou flores coloridas.

16- Grandes quantidades de árvores.

17- Com uma arborização densa, seria interessante se ela fosse frutífera, ou uma florida como um ipê, ou purificante como um eucalípto.

18- Muitos coqueiros na avenida, muitos pé de jaca e melancia, muitos pés de ovo, pé de dinheiro, pé de craci, pé de mulher boa. 


\section{Respostas do Grupo de Terceira Idade:}

01-Na minha rua existem várias sibipirunas, gostaria que tivesse mais árvores com flores, tipo quaresmeiras de várias cores, árvores frutíferas.

02-Graças a Deus a arborização é ótima, tem até orquídeas nas árvores das ruas. Árvores frutíferas, Araçá, Carambola, Pitanga, Laranja.

03-A arborização precisa ser de acordo com a rua ou local ?????????, sendo assim, plantas floridas e baixas em ruas movimentadas. Quando com condições árvores que façam sombras e até frutíferas. 04-Gostaria que a rua que eu moro fosse arborizada com plantas que formasse uma copa que não danificasse a calçada e não produzisse sujeira. Com árvores vistosas e fortes.

05-Gostaria que somente tivesse árvores cuidadas com amor e compreensão de seu valor para a vida. 06-Gostaria que fosse arborizada com árvores de porte médio e com flores. Gosto muito de admirar árvores ou arbustos floridos.

\section{- "Muro das Lamentações"}

\section{Pergunta 3: Quais são os problemas que as árvores trazem aos moradores em sua rua?}

\section{Respostas do grupo de jovens:}

Destrói as calçadas, entope os bueiros, brigas com vizinhos, sujeira, morcego.

Destruição das calçadas, entupimento de calhas, abala as estruturas das casas, problemas com a rede elétrica, criação de pica-paus.

Infelizmente elas trazem o entupimento das calhas, a quebra das calçadas, "sujeira" nas ruas.

Um dos maiores problemas são os mais velhos que não aguentam varrer a calçada, cortando as árvores.

É a hora dos "teletubies" Oi....

Desenho de uma árvore grande com alguém varrendo a calçada cheia de folhas e a copa da árvore alcançando a fiação elétrica.

As árvores trazem um problema para os moradores de poda, de quebra de calçada, e "invasão".

Muitos passarinhos: muita sujeira, muitas folhas, atrapalha os fios dos postos, atrapalha as pessoas que passam na rua.

Sujeira com a queda de folhas, flores e galhos, quebra de calçadas por causa das raízes, problemas com instalações elétricas, pois os galhos batem nos fios, podendo causar curto-circuitos, entupimento de calhas, causado por folhas e flores, acidentes, como bater com a cara na árvore e tropeçar nas raízes.

Descalçamento, entupimento das calhas, transtorno dentre as fiações, invadimento dos galhos dentre as construções, na falta do exercício da poda, o morador acaba condenando-a . P.S. coisa que as árvores não deviam trazer problema algum.

Danos nas calçadas, danos na rede elétrica, sujeira nas casas e calçadas, entopem as calhas.

Destrói as calçadas, entope os bueiros, brigas com os vizinhos.

Quebram as calçadas, entopem calhas, muita sujeira nas calçadas e rua, brigas com vizinhas.

Quebram as calçadas, entopem calhas, muita sujeira nas calçadas e ruas, brigas com vizinhos (*)

Sujeira das folhas, calçadas levantadas pelas raízes, fiação força/telefone/tv, uma rua bem arborizada, penso eu, que deva ter também uma boa iluminação à noite, devido à má segurança. A sujeira das folhas pode ser resolvida fazendo uma cova maior e mais profunda (se comparado com o nível da rua) para que a sujeira (folhas) da árvore possam ser colocadas nesta cova.

Entupimento de calhas, levantamento de calçadas, desgaste de vassouras, problemas com rede elétrica, fator positivo das árvores: servem para fazer sombra para os carros do vizinho, emprega a população (gari, varredores de rua) - fator bom.

Entupimento de calhas, levantamento de calçadas, desgaste de vassoura, problemas com rede elétrica, fator positivo das árvores: serve para fazer sombra para os carros dos vizinhos, emprega a população (gari, margarida, etc). 
Entupimento de calhas, levantamento de calçadas, desgaste de vassouras, problemas com a rede elétrica, fator positivo das árvores: serve para fazer sombra para os carros do vizinho, com a poda das árvore aumenta o desemprego.

Você sabia? Cada ser humano, produz em média 1,5 ton. de gás carbônico ao cano, e que é esse gás que é um causador da destruição da camada de ozônio? O que seríamos de nós sem elas.

Trinca as calçadas, as flores e folhas sujam as ruas, quando elas crescem não deixa o fio das ruas passar.

Não causam nenhum problema. É como a Ilza disse, é o povo que faz o lugar das árvores pequeno pois ela é como nós que crescemos. O único problema que podem causar é um curto circuito quando chegam a altura do fio.

Entupir calhas, estragar calçadas, etc...

Problemas: sujeira, quebra das calçadas, problemas com a fiação dos postes, entupimento das calhas.

Quebra de calçadas, sujeira nas calçadas, entopem calhas, defeito nas redes elétrica.

\section{Respostas do Grupo de Terceira Idade:}

01-Se fosse bem planejados, as plantações não seriam problemas. Mas muitas árvores que trazem problemas com folhas que caem na rua com danificação de calçadas. Assim trazem problemas aos moradores.

02-Orientar quem vai plantar a árvore. Plantar as árvores próprias para o local. As árvores tem que ser cuidadas para não dar problemas aos outros moradores.

03-Conforme a árvore traz os seguintes problemas: Quando plantadas perto da casa estraga a calçada, entope calha, chega até prejudicar o alicerce das casas. Queda de árvores sobre casas, carros, etc. Coisas boas de uma árvore: Purifica o ar. Faz sombra.

04-Dependendo do local e vizinhança, poderá trazer problemas como: Sujeira, como folhas, galhos, etc.; pássaros, morcegos e outros insetos; Compensação: sombra, beleza, frescor, saúde, oxigênio, etc.

05-As árvores podem trazer alguns problemas como quebrar calçadas (se não forem espécies apropriadas), queda das folhas entopem as calhas. Mas para mim os benefícios que elas trazem são muito maiores como a sombra, o ensinamento da natureza, a purificação do ar.

06-A árvore só traz problemas quando plantada em área inadequada ou espécie inadequada para cada ambiente. Se for bem planejada e cuidada não tem como ser problema. 